\title{
ECOTURISMO NO PARQUE NACIONAL DE BRASÍLIA
}

Sabrina Alessandra Ruscher

Gustavo Souto Maior Salgado

Monografia apresentada ao Centro de Excelência em Turismo da Universidade de Brasília como requisito parcial para a obtenção do certificado de Especialista em Ecoturismo.

Brasília, DF, maio de 2003. 
FOLHA DE ROSTO

UNIVERSIDADE DE BRASÍLIA

Centro de Excelência em Turismo

Curso de Especialização em Ecoturismo

\section{ECOTURISMO NO PARQUE NACIONAL DE BRASÍLIA}

Sabrina Alessandra Ruscher

Banca Examinadora

Gustavo Souto Maior Salgado

Mestre em Gestão Econômica do Meio Ambiente

Orientador

Nome, (titulação).

Membro da Banca

Brasília, DF, 26 de maio de 2003 
Ruscher, Sabrina Alessandra Ecoturismo no Parque Nacional de Brasília/ Sabrina Alessandra Ruscher.-- Brasília: UnB/CET, 2003.

iv, 72 p.: il.

Monografia (Especialização) - Universidade de Brasília, Centro de Excelência em Turismo, 2003.

1.Turismo. 2.Ecoturismo. 3.Parques Nacionais. -Monografia

I.Monografia (Especialização) - Centro de Excelência em Turismo.II.Ecoturismo no Parque Nacional de Brasília. 


\section{FOLHA DE APROVAÇÃO \\ SABRINA ALESSANDRA RUSCHER}

Ecoturismo no Parque Nacional de Brasília.

Comissão Avaliadora

Professor Orientador

\section{Professor "A"}

Professor "B"

Brasília, DF, 26 de maio de 2003. 


\section{Folha da Dedicatória}

\section{DEDICATÓRIA}

Dedico este trabalho a toda minha família, principalmente ao meu filho Igor Alessandro Ruscher, aos meus pais, Nelson Ruscher e Sonia Amaral Ruscher, aos meus irmãos, Nelson Alexandre Ruscher e Rafael Augusto Ruscher, pessoas das quais eu amo muito e que sempre acreditam em meu sucesso.

Dedico ao Fabrício, uma pessoa muito especial na minha vida e meu grande companheiro para todos os momentos.

Dedico também a todos meus amigos, colegas e professores da UnB/Cet do curso de Ecoturismo. 


\section{Folha(s) dos Agradecimentos}

\section{AGRADECIMENTOS}

Agradeço primeiramente a Deus que me permitiu a realização deste.

Agradeço especialmente ao Gustavo Souto Maior Salgado, amigo e orientador desta monografia. 


\section{FOLHA DE APROVAÇÃO}

\section{EPÍGRAFE}

\section{O TEMPO NOS PARQUES}

O tempo nos parques é íntimo, inadiável, imparticipante, imarcescível. Medita nas altas frondes, na última palma da palmeira

$\mathrm{Na}$ grande pedra intacta, o tempo nos parques.

O tempo nos parques cisma no olhar cego dos lagos

Dorme nas furnas, isola-se nos quiosques

Oculta-se no torso muscular dos fícus, o tempo nos parques.

O tempo nos parques gera silêncio do piar dos pássaros

Do passar dos passos, da cor que se move ao longo.

É alto, antigo, presciente o tempo nos parques

É incorruptível; o prenúncio de uma aragem

A agonia de uma folha, o abrir-se de uma flor

Deixam um frêmito no espaço do tempo nos parques.

O tempo nos parques envolve de redomas invisíveis

Os que se amam; eterniza os anseios, petrifica

Os gestos, anestesia os sonhos, o tempo nos parques.

Nos homens dormentes, nas pontes que fogem, na franja

Dos chorões, na cúpula azul o tempo perdura

Nos parques; e a pequenina cutia surpreende

A imobilidade anterior desse tempo do mundo

Porque imóvel, elementar, autêntico, profundo

É o tempo nos parques.

Vinícius de Moraes 


\section{FOLHA DE APROVAÇÃO}

\section{RESUMO}

O Ecoturismo pode servir como ferramenta para o desenvolvimento sustentável de Parques Nacionais. Através de processos participativos da comunidade na gestão destas áreas é possível identificar os pontos onde devem ser feitas melhorias.

Os Parques Nacionais estão dentro de uma das categorias de unidades de conservação mais conhecidas do público. Eles possibilitam o contato com a natureza e conseqüentemente o Ecoturismo. Este é um fato muito importante, pois as novas tendências mundiais apontam que as Uc's não sobreviverão se não se integrarem a uma gestão eficiente e adequada. $O$ turismo gerado pela oportunidade de visitação nestas áreas pode, se bem administrado, trazer benefícios econômicos para a própria unidade e também para as comunidades.

A presente monografia evidencia que através de uma gestão participativa é possível o desenvolvimento do Ecoturismo no Parque Nacional de Brasília (PNB). Além disso, reflete o perfil e visão de seus freqüentadores no que diz respeito a preservação e uso do PNB.

Palavras- chave : Parques Nacionais, Ecoturismo e Gestão. 


\section{FOLHA DE APROVAÇÃO}

\section{ABSTRACT}

Ecotourism can aid sustainable development in National Parks. Through processes were the community can participate in the administration of these areas it's possible to identify were improvements can be made.

National Parks are in the category of the most known conservation units. They make possible the human contact with nature and consequently with Ecotourism. This is a very important fact, since new worldwide tendencies point out that these conservation units cannot survive if they don't integrate themselves with an efficient and modern administration. The tourism that comes from the opportunity of visiting these areas can bring economic benefits for the community and for the area itself as long as it's well administrated.

This work was done to show that an administration model involving the community is possible in the National Park of Brasilia. It also reflects the profile and vision of the park's visitors when it comes to the preservation and use properties of the National Park of Brasilia.

Key- words: National Parks, Ecotourism and Administration. 


\section{FOLHA DE APROVAÇÃO}

\section{SUMÁRIO}

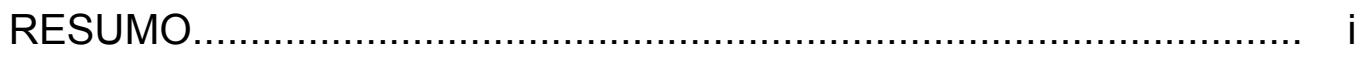

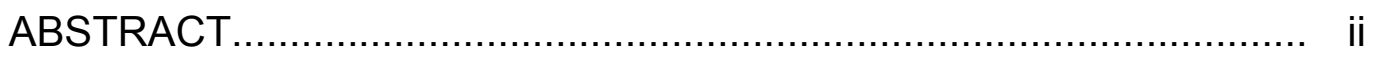

LISTA DE ILUSTRAÇÕES............................................................ 01

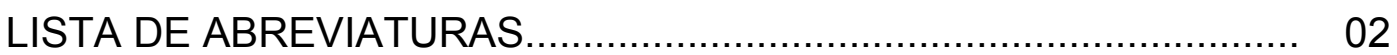

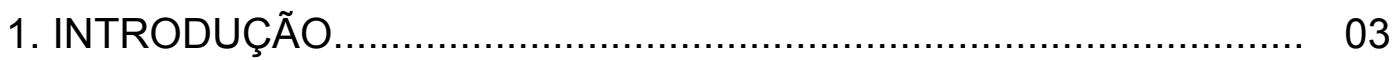

1.1 Objetivo Geral......................................................................... 04

1.2 Objetivos Específicos............................................................ 04

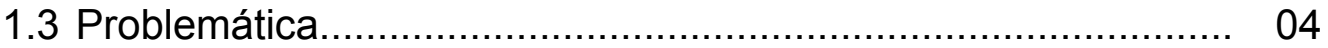

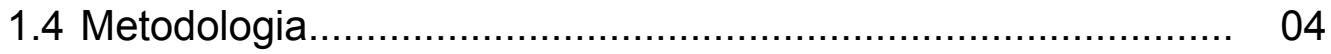

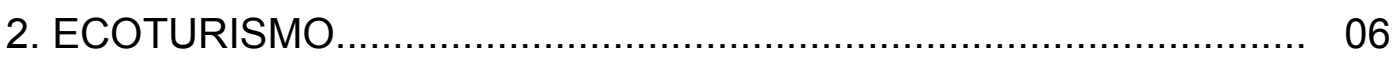

2.1 Turismo Sustentável................................................................. 09

2.2 Ecoturismo em Parques Nacionais............................................ 12

2.3 Impactos do Ecoturismo........................................................ 15

3. PARQUES NACIONAIS E GESTÃO.............................................. 18

3.1 Parques Nacionais.............................................................. 18

3.2 Gestão em Parques Nacionais................................................. 19

3.3 Participação Local............................................................. 22

3.4 Arrecadação e Concessões...................................................... 24

4. PARQUE NACIONAL DE BRASÍLIA........................................... 25

4.1 Antecedentes Legais.......................................................... 25

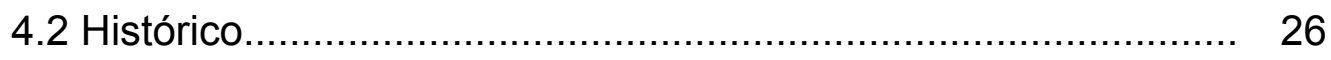

4.3 Localização, limites e vias de acesso....................................... 27

4.4 Análise da vegetação/Cerrado............................................... 28

4.5 Análise da fauna ................................................................ 30 


\section{FOLHA DE APROVAÇÃO}

4.6 Recursos Hídricos/Hidrologia................................................. 31

4.7 Problemas enfrentados pelo PNB........................................... 33

4.8 Plano de Manejo do PNB.................................................... 35

4.9 Infra-estrutura de visitação.................................................... 36

4.10 Gestão no PNB................................................................... 38

4.11 Oportunidades de Negócios................................................. 41

5. PESQUISA DE VISITAÇÃO........................................................ 43

6. DISCUSSÃO DOS RESULTADOS ............................................. 51

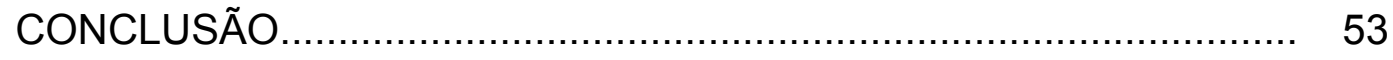

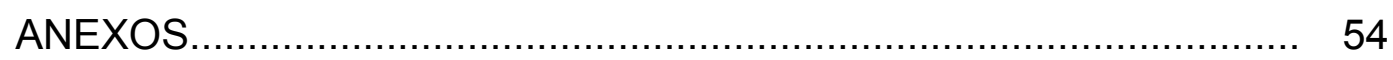

REFERÊNCIAS BIBLIOGRÁFICAS................................................ 68

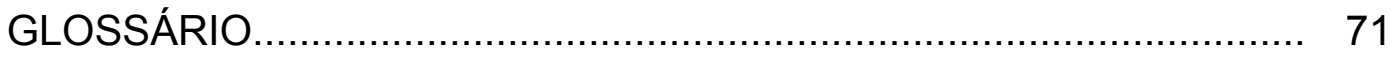




\section{FOLHA DE APROVAÇÃO \\ LISTA DE ILUSTRAÇÕES}

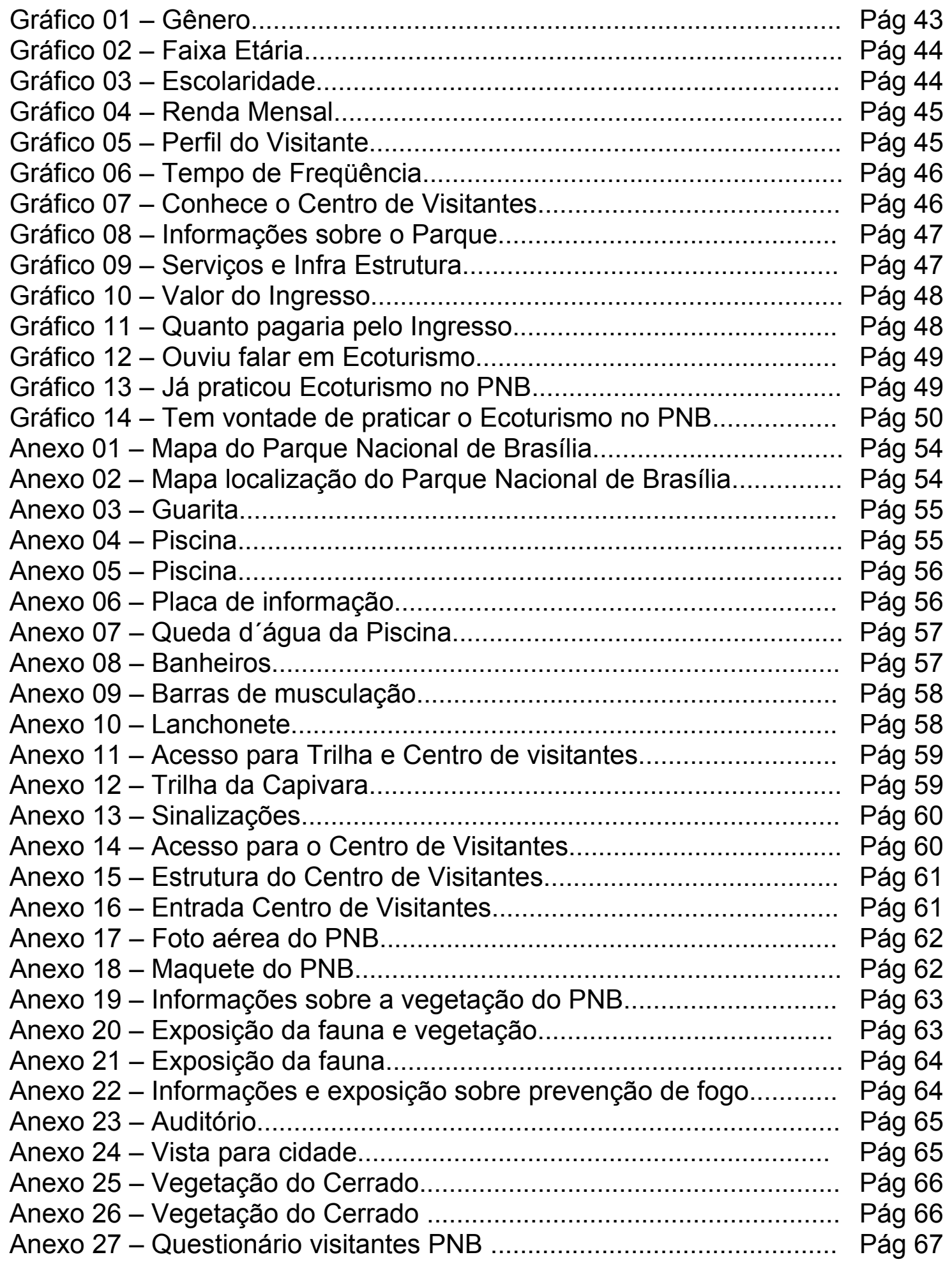


FOLHA DE APROVAÇÃO

LISTA DE ABREVIATURAS

\begin{tabular}{|l|l|}
\hline BR & Brasil \\
\hline CEMAVE & Conservação das Aves Silvestres \\
\hline CISET & Secretaria Federal de Controle Interno \\
\hline DF & Distrito Federal \\
\hline DIREC & Diretoria de Ecossistemas \\
\hline ECOBRASIL & Associação Brasileira de Ecoturismo \\
\hline EMBRATUR & Instituto Brasileiro de Turismo \\
\hline ENEB & Encontro Nacional de Estudantes de Biologia \\
\hline EPAC & Estrada Parque Acampamento \\
\hline EPCL & Estrada Parque Ceilândia \\
\hline EPCT & Estrada Parque contorno \\
\hline EPIA & Estrada Parque de Indústria e Abastecimento \\
\hline FBCN & Fundação Brasileira para Conservação da Natureza \\
\hline FUNATURA & Fundação Pró-Natureza \\
\hline FUNGETUR & Fundo Geral do Turismo \\
\hline IBAMA & Instituto Nacional do Meio Ambiente e Recursos Naturais \\
\hline IBDF & Instituto Brasileiro de Desenvolvimento Florestal \\
\hline IUCN & $\begin{array}{l}\text { International Union for Conservation of Nature and } \\
\text { Natural Resources }\end{array}$ \\
\hline MMA & Ministério do Meio Ambiente \\
\hline NOVACAP & Companhia Urbanizadora da Nova Capital \\
\hline OMT & Organização Mundial de Turismo \\
\hline ONG S & Organizações não governamentais \\
\hline PARNA OU PN & Parques Nacionais \\
\hline PDOT & $\begin{array}{l}\text { Plano Diretor de Ordenamento Territorial do Distrito } \\
\text { Federal }\end{array}$ \\
\hline PRODETUR & $\begin{array}{l}\text { Programa de Ação para o Desenvolvimento Integrado do } \\
\text { Turismo }\end{array}$ \\
\hline SNUC & $\begin{array}{l}\text { Sistema Nacional de Unidades de Conservação da } \\
\text { Natureza }\end{array}$ \\
\hline UC'S & Unidade de Conservação \\
\hline UNESCO & $\begin{array}{l}\text { Organização das Nações Unidas para Educação, } \\
\text { Ciência e Cultura. }\end{array}$ \\
\hline
\end{tabular}




\section{FOLHA DE APROVAÇÃO}

\section{INTRODUÇÃO}

O Ecoturismo esta ganhando maturidade no Brasil como alternativa econômica, juntamente com importantes componentes de conservação dos ecossistemas. Isso se manifesta através do profissionalismo com que este setor vem sendo conduzido pelos atores responsáveis por ele.

O Parque Nacional de Brasília é uma das mais importantes Unidades de Conservação (UC'S) do Distrito Federal, que abriga áreas com elementos representativos da flora e fauna do Bioma Cerrado em admirável grau de preservação. Em virtude da importância de se proteger e usufruir toda essa riqueza existente dentro do PNB existe a oportunidade da implantação do Ecoturismo como alternativa sustentável. Esta prática também pode resultar em um desenvolvimento econômico compatível com a preservação ambiental.

Os Parques Nacionais (PARNA ou PN) comportam a visitação pública com fins recreativos e educacionais, regulamentada pelo Plano de Manejo da unidade. As pesquisas científicas, quando autorizadas pelo órgão responsável pela sua administração, estão sujeitas a determinadas condições por este, bem como ao que for definido em seu Plano de Manejo.

Projetos de Ecoturismo têm despertado o interesse tanto de governos como de empresários, em razão do crescimento que a atividade vêm demonstrando nos últimos anos e de todas as tendências que apontam para um futuro promissor.

O estudo desta monografia é a oportunidade de se fazer chegar ao conhecimento da sociedade, não só a beleza do Parque Nacional de Brasília, mas também as necessidades implícitas para sua gestão. Através do Ecoturismo a sociedade terá a opção de conviver com a natureza de forma sustentável, podendo assim ter uma melhor qualidade de vida. O Ecoturismo beneficiará o Bioma Cerrado e a conservação do mesmo de forma a contribuir com que os recursos que hoje são utilizados se mantenham suficientes e disponíveis para o uso das gerações futuras. 


\section{FOLHA DE APROVAÇÃO}

\subsection{Objetivo Geral}

O objetivo geral desta monografia é analisar a viabilidade do ecoturismo em bases sustentáveis no Parque Nacional de Brasília com a participação da comunidade em sua gestão, conscientização e conservação ambiental.

\subsection{Objetivos Específicos}
A. Identificar através de questionários o perfil do visitante do PNB;
B. Mostrar a intensidade da prática do Ecoturismo no PNB;
C. Evidenciar a demanda por melhorias de serviços e infra-estrutura;

\subsection{Problemática}

O trabalho desenvolve um estudo que possibilita identificar a principal dificuldade para o aproveitamento ecoturístico no Parque Nacional de Brasília, que é a gestão centralizada imposta pelo IBAMA. Essa gestão não envolve a participação da comunidade e de outros atores interessados nas decisões de benefícios e melhorias no PNB.

\subsection{Metodologia}

Este trabalho é fundamentado em revisões bibliográficas, pesquisa de campo, entrevistas formais e informais com os visitantes do Parque e autoridades envolvidas.

A pesquisa de campo foi realizada com o objetivo de registrar, sistematizar e coletar dados, possibilitando, desta forma, uma aproximação maior da realidade local e uma investigação das questões relacionadas ao assunto.

Os dados foram colhidos a partir de fontes bibliográficas e documentais, como: livros, artigos, estudos teóricos, revistas científicas e publicações governamentais do IBAMA, EMBRATUR e MMA. 


\section{FOLHA DE APROVAÇÃO}

As entrevistas foram feitas através de questionários que relatam dados sobre os perfis dos visitantes que freqüentam o Parque, o próprio Parque e o Ecoturismo. 


\section{FOLHA DE APROVAÇÃO}

\section{ECOTURISMO}

O Ecoturismo é um segmento relativamente novo do turismo de natureza. O que diferencia dos outros é que ele abrange em sua conceituação a experiência educacional interpretativa, a valorização das culturas tradicionais locais, a promoção da conservação da natureza e do desenvolvimento sustentável. Diferentemente do turismo de caça e pesca, usam-se os recursos naturais de forma indireta, isto é, não se retira nada do ambiente, que é apenas apreciado (Kinker, 2002) ${ }^{1}$.

Segundo o Ministério do Meio Ambiente (MMA), o Ecoturismo "é um ramo do turismo que utiliza recursos naturais e culturais de um determinado lugar e contribui para conservá-los. Busca desenvolver o respeito da natureza por meio do contato com o ambiente natural e promove o bem estar das populações locais envolvidas".

De acordo com o IBAMA ${ }^{2}$ o Ecoturismo "é uma atividade estratégica capaz de gerar empregos, capacitação profissional e distribuição de renda às populações que habitam o entorno das Unidades de Conservação. 0 ecoturismo possibilita a existência de um grande programa de educação ambiental através da interação entre turistas e natureza, ajuda a consolidar o patrimônio ambiental e pode fazer dos Parques Nacionais a porta de entrada do turista no Brasil".

O Ecoturismo é caracterizado pela EMBRATUR ${ }^{3}$ como "um segmento da atividade turística que utiliza de forma sustentável o patrimônio natural e cultural, incentiva sua conservação e busca a formação de uma consciência

\footnotetext{
${ }^{1}$ KINKER, Sônia. Ecoturismo e conservação da natureza em parques nacionais. Coleção Turismo - Campinas, SP: Papirus, 2002.

2 IBAMA -Instituto Brasileiro do Meio Ambiente e dos Recursos Naturais Renováveis - é a agência governamental encarregada de executar as políticas de meio ambiente no âmbito do governo federal. Tem entre suas atribuições a função de coordenar e fomentar a conservação de ambientes naturais representativos dos ecossistemas brasileiros. <http://www.ibama.gov.br>

3 EMBRATUR, INSTITUTO BRASILEIRO DE TURISMO/MINISTÉRIO DO TURISMO. $<$ http://www.embratur.gov.br>
} 


\section{FOLHA DE APROVAÇÃO}

ambientalista através da interpretação do ambiente, promovendo o bem estar das populações envolvidas".

Com isso, o Ecoturismo tem como princípio o equilíbrio entre a utilização e a conservação das áreas naturais visitadas e conseqüentemente o desenvolvimento sócio-econômico do local.

As tendências mundiais apontam para uma diversificação dos mercados, satisfazendo os mais variados motivos que levam pessoas a se deslocarem. Assim, o produto turístico cada vez mais estará voltado a atender as expectativas da demanda, e a qualidade é o diferencial que possibilitará a "sobrevivência" no mercado.

Segundo a EcoBrasil ${ }^{4}$, o Ecoturismo é também compreendido popularmente como turismo "natural", indo além da simples observação, propiciando ao turista um entendimento ecológico do meio natural.

\section{O Ecoturismo deve:}

- Promover e desenvolver turismo com bases culturais e ecologicamente sustentáveis;

- Promover e incentivar investimentos em conservação dos recursos culturais e naturais utilizados;

- Fazer com que a conservação beneficie materialmente as comunidades envolvidas, pois somente servindo de fonte de renda alternativa estas se tornarão aliadas de ações conservacionistas;

- Ser operado de acordo com critérios de mínimo impacto para ser uma ferramenta de proteção e conservação ambiental e cultural;

- Educar e motivar pessoas através da participação em atividades que estimulem a percepção da importância de áreas naturais e culturalmente conservadas.

\footnotetext{
${ }^{4}$ EcoBrasil - Associação Brasileira de Ecoturismo - A EcoBrasil acredita, que a existência de uma entidade de profissionais do ramo de ecoturismo possa promover a articulação e ordenamento, não somente para reverter a atual situação do Ecoturismo no país, como também para fazer do Brasil um destino ecoturístico confiável e sustentável. $<$ http://www.ecobrasil.org.br>
} 


\section{FOLHA DE APROVAÇÃO}

Segundo a $\mathrm{OMT}^{5}$, entre todos os tipos de turismo existentes, o Ecoturismo é o que mais tem se desenvolvido. Enquanto a atividade turística cresce a uma taxa média anual de $7,5 \%$, o Ecoturismo cresce a uma taxa de $10 \%$ a $30 \%$ ao ano.

No Brasil, o mercado do Ecoturismo conta com meio milhão de turistas, gerando $30 \mathrm{mil}$ empregos diretos. Com investimentos corretos e projetos sustentáveis, essa atividade econômica deverá crescer bem mais, gerando emprego, renda e oportunidades de negócios. (MMA)

O Governo Federal vem criando mecanismos para fomentar o turismo no Brasil, através da EMBRATUR, que criou mecanismos como:

- O PRODETUR - Programa de Ação para o Desenvolvimento Integrado do Turismo, um programa global de desenvolvimento turístico regional, estruturado e concebido pelos Governos Federal e Estaduais, para financiar a implantação de infra-estrutura de suporte ao turismo, propiciando e incentivando investimentos da iniciativa privada para implantação de equipamentos turísticos. É a primeira experiência no campo de desenvolvimento turístico regional a ser implementada no País, com financiamento externo.

- O FUNGETUR - Fundo Geral de Turismo, é uma linha de crédito, que tem por finalidade de facilitar para os investidores o acesso aos recursos necessários para a implantação, melhoria, conservação e manutenção de empreendimentos e serviços turísticos.

Os projetos ecoturísticos podem ser classificados com a finalidade de:

- Implantação - quando se trata de criar uma unidade totalmente nova na oferta de bens e serviços.

\footnotetext{
${ }^{5}$ OMT, Organização Mundial de Turismo - Dados e tendências mundiais. <http://www.world-tourism.org>
} 


\section{FOLHA DE APROVAÇÃO}

- Expansão ou ampliação - quando, em razão da demanda ou de uma capacidade ociosa se objetiva o aumento na oferta de serviços.

- Modernização - quando se torna necessário a substituição de equipamentos, modificações no sistema administrativo e de comercialização, o aperfeiçoamento de recursos humanos, mas é mantida a mesma capacidade de oferta de serviços.

A elaboração de um projeto ecoturístico não pode estar atrelada à vontade política ou pessoal, uma vez que gera resultado de estudos de variáveis que interferem na sua identificação, na definição de necessidades insatisfeitas e de soluções que atendam às expectativas dos consumidores, de forma a garantir o sucesso e não o fracasso de um empreendimento ou de um destino.

\subsection{Turismo Sustentável}

Considerando que o Ecoturismo é uma tendência em termos de turismo mundial que aponta para o uso sustentável de atrativos no meio ambiente e nas manifestações culturais, devemos ter em conta que somente terá condições de sustentabilidade caso haja harmonia e equilíbrio no "diálogo" entre os seguintes fatores: resultados econômicos, mínimos impactos ambientais e culturais, satisfação dos ecoturistas (visitante, cliente, usuário) e das comunidades visitadas.

Nesta busca pelo natural, surgem conceitos ligados a sustentabilidade ecológica, ambiental, econômica, social e cultural, política. Estas questões têm se tornado critérios básicos para projetos de desenvolvimento sustentável.

Entre essas diferentes dimensões, destacam-se aqui desenvolvidas por Guimarães, $1994^{6}$ e por Sachs, $1993^{7}$ :

\footnotetext{
${ }^{6}$ GUIMARÃES, R. P. El desarrollo sustentable: propuesta alternativa o retorica neoliberal? Revista Eure, vol. XX, n. 61. Santiago Del Chile, 1994.

${ }^{7}$ SACHS, Ignacy. Estratégias de transição para o Séc. XXI: desenvolvimento e meio ambiente. São Paulo: Studio Nobel, Fundação do Desenvolvimento Administrativo, 1993.
} 


\section{FOLHA DE APROVAÇÃO}

- Sustentabilidade ecológica - refere-se à base física do processo de crescimento e tem como objetivo a manutenção de estoques de capital natural, incorporados às atividades produtivas.

- Sustentabilidade ambiental - refere-se à manutenção da capacidade de sustentação dos ecossistemas, o que implica a capacidade de absorção e recomposição dos ecossistemas em face das agressões antrópicas.

- Sustentabilidade social e cultural - refere-se ao desenvolvimento e tem por objetivo a melhoria da qualidade de vida da população. Para o caso de países com problemas de desigualdades e de exclusão social e cultural, implica a adoção de políticas distributivas e a universalização de atendimento a questões como saúde, educação, habitação e seguridade social.

- Sustentabilidade política - refere-se ao processo de construção da cidadania para garantir a incorporação plena dos indivíduos ao processo de desenvolvimento.

- Sustentabilidade econômica - refere-se a uma gestão eficiente dos recursos em geral e caracteriza-se pela regularidade de fluxos do investimento público e privado. Implica a avaliação da eficiência por processos macro sociais.

O conceito de Desenvolvimento Sustentável pressupõe a necessidade não apenas de se deter o consumo excessivo, nem tão pouco uma idéia de não-desenvolvimento ou desenvolvimento zero, mas uma noção de desenvolvimento que se auto-sustente, através da preocupação com a capacidade de suporte da natureza, e ainda transferindo a noção de desenvolvimento econômico para uma visão mais geral que inclua a natureza, as sociedades, as culturas, enfim, um desenvolvimento sócio-econômico eqüitativo e holístico (Figueiredo,1996) ${ }^{8}$.

Para que se possa ter um Desenvolvimento Sustentável do turismo é de suma importância que se faça o uso racional do meio ambiente, encontrando o equilíbrio entre interesses econômicos e o desenvolvimento de atividades que

\footnotetext{
${ }^{8}$ FIGUEIREDO, Silvio Lima. Turismo e Cultura. In: LEMOS, Amália (org.). Turismo: impactos sócio-ambientais. São Paulo, 1996.
} 


\section{FOLHA DE APROVAÇÃO}

o protejam, principalmente, porque o seu controle depende de critérios e valores subjetivos, além de uma política ambiental adequada.

O Turismo Sustentável surgiu como um segmento de extrema força e passou a ser visto como um outro tipo de turismo, também denominado de "alternativo" ou de "turismo de natureza", se contraponto ao turismo de massa. Esta sustentabilidade depende de como a atividade é planejada e executada, considerando os aspectos do meio ambiente da área visitada, sua economia e seus fatores sociais. (FORTE,2000) ${ }^{9}$

Deve-se levar em conta critérios de sustentabilidade e que atendam a anseios e demandas:

- Ser ecologicamente suportado e ao mesmo tempo economicamente viável;

- Distribuir eqüitativamente seus benefícios;

- Observar a ética, e ser socialmente aceito pela comunidade receptora;

- Estar integrado com todos os aspectos do ambiente, respeitando áreas frágeis bem como a capacidade de carga das áreas visitadas;

- Incentivar a participação de todos os atores envolvidos, pois a conservação da herança cultural e natural envolve cooperação, planejamento e manejo;

- Garantir a satisfação do turista ao mesmo tempo direcionando o seu comportamento, no sentido da conservação dos ambientes e respeito à cultura local (isso deve ser determinado em conjunto com a comunidade);

- Estar integrado com a economia local e promover a melhoria da qualidade de vida da comunidade receptora; 


\section{FOLHA DE APROVAÇÃO}

- Realizar ações de marketing responsável;

- Realizar pesquisas;

- Ser monitorado.

Segundo Wall, $(1997)^{10}$, o Turismo Sustentável pode ser definido como:

"Aquele que é desenvolvido e mantido em uma área (comunidade, ambiente) de maneira, e em uma escala que, se mantenha viável pelo maior tempo possível, não degradando ou alterando o meio ambiente de que usufrui (natural e cultural), não interferindo no desenvolvimento de outras atividades e processos, não degradando a qualidade de vida da população envolvida, mas pelo contrário servindo de base para uma diversificação da economia local."

\subsection{Ecoturismo em Parques Nacionais}

A proposta de abertura do Ecoturismo em Parques Nacionais ganha contornos mais definidos com a cessão de áreas para exploração pela iniciativa privada. O Ecoturismo em Parques Nacionais é considerado uma oportunidade de negócios e, em sua primeira fase, pretende atrair investimentos para adequar a infra-estrutura dos espaços à visitação pública.

O Ecoturismo é uma atividade estratégica capaz de gerar empregos, capacitação profissional e distribuição de renda às populações que habitam o entorno dos Parques. Além disso, possibilita a existência de programas de educação ambiental por meio da interação entre a comunidade, turistas e a natureza, além de ajudar a consolidar o patrimônio ambiental podendo fazer dos Parques Nacionais a porta de entrada do turista no Brasil.

\footnotetext{
${ }^{10}$ Wall, G. (1997)."Is ecotourism sustainable?”. Emvironmental Management, nº4, vol.21.
} 


\section{FOLHA DE APROVAÇÃO}

No Brasil temos exemplos de Parques que desenvolvem o Ecoturismo com grande sucesso. Um exemplo é o Parque Nacional da Chapada dos Veadeiros criado pelo Decreto N. ${ }^{\circ} 70.492$ de 11 de maio de 1972, alterado pelo Decreto N. ${ }^{\circ} 86.596$, de 17 de novembro de 1981, com área de 66.000 ha, localizado em Alto Paraíso - GO. O município possui uma crescente estrutura, com pousadas, hotéis e áreas de camping, e a cidade está a cerca de 1.300 mts. Visitantes de todas as partes vão até lá ver a maravilha selvagem e praticamente intacta do Parque Nacional da Chapada dos Veadeiros. Ainda hoje, se encontra dentro do Parque, animais em processo de extinção, como o veado -campeiro, o lobo-guará, a capivara, as ágeis emas e os tucanos-debico-amarelo.

Outro exemplo é o Parque Nacional do Iguaçu, que é um dos Parques mais visitados do Brasil, criado em 10 de junho de 1939, seguindo os passos da Argentina, que criou o Parque Nacional del Iguazú em 1934, apesar da idéia de preservação existir desde o século 19. Foz do Iguaçu tem atraído a atenção de inúmeros turistas. Somente no ano passado, o Parque Nacional recebeu a visita de aproximadamente 800 mil visitantes. O contato permanente do homem com a natureza faz de Foz do Iguaçu um centro de referência para o Ecoturismo. Diversas passarelas permitem observar o espetáculo das cataratas mais de perto. Existem passeios mesclando trilhas e trecho de barco até bem perto da Garganta do diabo, a mais bonita de todas as quedas. Também é possível realizar um vôo panorâmico de helicóptero. O parque também protege totalmente a bacia do Rio Floriano.O Museu do Parque apresenta exposição com amostras da fauna e da flora regionais, peças etnográficas e artesanato tupi-guarani.

O Ecoturismo vem se expandindo, segundo dados da OMT enquanto o turismo cresce $7,5 \%$ ao ano, o Ecoturismo cresce mais de $15 \%$. O segredo esta na sustentabilidade (conceito que praticamente só existe na teoria ainda) dos atrativos para não comprometer gerações futuras. Por esse motivo o principal objetivo deste é a criação de estratégias para utilização correta desses patrimônios pela humanidade e, ao mesmo tempo, o desenvolvimento de uma exploração adequada dos recursos naturais e a conscientização das populações envolvidas. 


\section{FOLHA DE APROVAÇÃO}

"Há consenso entre os empresários de que o Ecoturismo é um mercado em grande expansão, sendo estimado o seu crescimento em cerca de $20 \%$ ao ano, conforme resultados obtidos em entrevistas realizadas junto a operadoras turísticas especializadas e peritos, e na observação do crescimento de agências operadoras de ecoturismo" (Ziffer, 1989) ${ }^{11}$.

A política do Ecoturismo promove uma série de benefícios para a comunidade local e para o investidor. Dentre os maiores benefícios, destacamse:

- Preservação do maior produto turístico: o meio ambiente;

- Preservação dos aspectos culturais locais;

- Maior envolvimento com a população e conseqüentemente maior aceitação do projeto ecoturístico pela comunidade;

- Diminuição da utilização de recursos naturais esgotáveis, além da economia em energia, água e outros recursos;

- Projetos arquitetônicos condizentes com as características locais promovem maior sinergia entre o destino e seu desenvolvimento turístico.

- Evitando a depredação, ganha a comunidade com uma alternativa econômica para seus jovens e ganha o turista que recebe um serviço de informação e segurança quando visita o Parque.

Os Parques Nacionais representam, por seus valores bio-sócio-culturais, verdadeiras escolas conservacionistas ao ar livre. A Educação Ambiental visa à conscientização da sociedade relativa às questões ambientais que tem como grande contribuição para 0 crescimento da demanda de atividades ecoturísticas. De fato, a forte percepção mundial para as questões sócioambientais, vem estimulando a necessidade de urgência na proteção e na recuperação dos recursos naturais.

A carência de recursos humanos, principalmente em relação ao aspecto quantitativo, é um dos obstáculos para a proteção dos Parques Nacionais 


\section{FOLHA DE APROVAÇÃO}

Brasileiros. São destinados à Diretoria de Ecossistemas (DIREC), apenas 2\% do total dos recursos do IBAMA, uma porcentagem muito pequena que acaba prejudicando a realização de algumas atividades em Parques Nacionais.

\subsection{Impactos do Ecoturismo}

Os impactos do Ecoturismo referem-se a um conjunto de modificações ou seqüência de eventos, provocados pelo desenvolvimento da atividade nas localidades receptoras. Tais impactos resultam de um processo e não constituem eventos pontuais (Ruschmann, 1997) ${ }^{12}$. As variáveis que os provocam tem natureza e intensidades diversas, mas os resultados são geralmente irreversíveis quando ocorre no meio ambiente natural.

A proteção das espécies da fauna e da flora nativas de um país ou região só pode ser feita efetivamente pela preservação de porções significativas de seus ambientes naturais ou habitats. Assim, foram criadas as Unidades de Conservação, abrangendo amostras destes ambientes naturais, tendo como finalidade sua preservação e/ou conservação e se constituindo num instrumento de proteção da biodiversidade do País.

Preservar um ecossistema é garantir, para uma região, vida em equilíbrio. A destruição de algumas espécies pode provocar o aumento populacional de outras, gerando, assim, desequilíbrios com conseqüências danosas a todos que habitam um determinado local. É também, através da proteção de um ambiente que se pode assegurar um maior volume e a melhoria da qualidade das águas, condições que hoje, se encontram ausentes em grande parte de nossos mananciais. Em ambientes preservados ganha a natureza, portanto, todos ganham.

No Ecoturismo, o desenvolvimento sustentável preocupa-se com o impacto causado a natureza, enaltece os aspectos histórico-culturais do local e

\footnotetext{
${ }^{11}$ ZIFFER, K. A. E. Ecotourism: the uneasy alliance. Conservation International, Ernst \&Young, International Management Consulting Group ( Working Papers on Ecotourism,1) Washington, DC: Island Press, 1989.

${ }_{12}$ RUSCHMANN, Dores. Turismo e planejamento sustentável: A proteção do meio ambiente. Campinas: Papirus, 1997.
} 


\section{FOLHA DE APROVAÇÃO}

utiliza recursos naturais e mão-de-obra da região para a realização de projetos integrados ao meio-ambiente.

Com efeito, a fragilidade dos ecossistemas naturais, muitas vezes, não comporta o número elevado de visitantes e, menos ainda suporta o tráfego excessivo de veículos pesados. A infra-estrutura necessária, se não atendidas normas pré-estabelecidas, pode comprometer de maneira acentuada o meio ambiente, com alterações na paisagem, na topografia, no sistema hídrico e na conservação dos recursos naturais florísticos e faunísticos.

O Ecoturismo mais do que qualquer outra forma de turismo na natureza depende da qualidade do ambiente visitado. Esse é mais um motivo pelo qual a atividade deve ser controlada e seus potenciais impactos negativos devem ser minimizados pelo manejo (Kinker, 2002).

Segundo O MMA, O Ecoturismo apresenta significativos impactos positivos e negativos nos aspectos econômicos, sociais e ambientais:

Nos aspectos ambientais, quando bem planejado e monitorado, gera diversos aspectos positivos como destinar recursos financeiros para a conservação e incentivação de áreas degradadas, estimular levantamentos de fauna e flora e incentiva pesquisa científica, promover a educação ambiental e maior consciência ambiental nas populações, viabilizar tecnologias ambientais sustentáveis, estimular a implantação de infra-estrutura básica, saúde, comunicação, segurança, educação e comércio. Quando não ocorre o devido planejamento e monitoramento podem ocorrer impactos negativos como, alterar nos comportamentos, hábitos alimentares e na reprodução dos animais silvestres pelo excesso de visitação e/ou presença de lixo, comércio ilegal de espécies silvestres e de artesanatos que utilizam órgão, penas e couro de animais, poluição do ar, água, solo, sonora e visual, abertura de estradas, trilhas e atalhos inadequados e compactação e erosão do solo.

Quanto aos aspectos econômicos, se gera renda e emprego, utiliza-se da infra-estrutura existente, desenvolve-se através de produtos locais e complementa outras atividades locais. Estes podem gerar impactos negativos 


\section{FOLHA DE APROVAÇÃO}

através da inflação, em baixa temporada pode ocorrer desemprego (pois as atividades dependem das estações do ano), pode também haver prejuízos por conseqüência de boatos, doenças e mudanças no setor financeiro e a economia pode ficar dependendo do ecoturismo como fonte de renda.

Os aspectos culturais geram diversos pontos positivos como contribuir para educação, estimular o entendimento e a paz, reduzir barreiras entre pessoas em razão da raça, cor, sexo, origem cultural, política, ou religiosa. Quando não ocorre do devido planejamento e monitoramento gera antipatia pelo excesso de visitantes, descaracterização cultural do local, estimula o aumento da criminalidade.

Os impactos causados pelo Ecoturismo, seus custos e benefícios já são conhecidos. Não se sabe até que ponto esses benefícios podem ser maximizados e os custos minimizados. Mas sabe-se que, sem planejamento e sem boa administração, o Ecoturismo não terá sucesso. 


\section{PARQUES NACIONAIS E GESTÃO}

\subsection{Parques Nacionais}

Existem ao todo 184 Unidades de Conservação no país, das quais 49 são Parques Nacionais. Os Parques Nacionais são áreas protegidas que pertencem ao grupo de Unidades de Conservação de Proteção Integral e destinam-se à preservação integral de áreas naturais com características de grande relevância sob os aspectos ecológicos, belezas cênicas, científicas, culturais, educativas e recreativas (IBAMA).

Os Parques Nacionais destinam-se à preservação de ecossistemas naturais de grande relevância ecológica, cênica, científica, cultural, educativa e recreativa, onde é proibida qualquer interferência humana direta, com exceção de ações de manejo necessárias para sua administração. A visitação pública é permitida, mas esta sujeita às normas e restrições estabelecidas no plano de manejo da unidade, às normas estabelecidas pelo órgão gestor e àquelas previstas no regulamento dos Parques Nacionais Brasileiros. São áreas de domínio público $\left(\right.$ SNUC,2000) ${ }^{13}$.

São áreas geralmente muito extensas, que têm como objetivo básico a preservação de ecossistemas, a realização de pesquisas científicas e o desenvolvimento de atividades de educação e interpretação ambiental, de recreação em contato com a natureza e ecoturismo. O órgão responsável pelos Parques Nacionais do Brasil é o IBAMA, através do DIREC.

\footnotetext{
${ }^{13}$ SNUC - Sistema Nacional de Unidades de Conservação da Natureza, MMA. Brasília, 2000.
} 


\section{FOLHA DE APROVAÇÃO}

Os Parques Nacionais são abertos para visitações, por isso, devem obter um planejamento adequado que é essencial para bons resultados na preservação destes espaços. A maior parte do sucesso depende das diretrizes e métodos adotados para nortear a prática do Ecoturismo. Devem possuir atração significativa para o público, oferecer oportunidade de recreação, educação ambiental, pesquisas e estudos. Dentro dos Parques Nacionais é proibida qualquer forma de exploração dos recursos naturais.

Foi estendida a todos os tipos de Unidades de Conservação Ambiental a concepção dos planos de manejo, envolvendo parques nacionais, reservas biológicas, reservas florestais, reservas legais, áreas de proteção ambiental, e outros.

O IBAMA produziu um termo de referência para a elaboração de planos de manejo em unidades de conservação ambiental, envolvendo as tarefas de zoneamento e uma série de programas específicos destinados a garantir e manter a estabilidade ambiental das áreas manejadas.

O Decreto $N^{\circ}$ 84.017, de 21 de setembro de 1979, que aprova o Regulamento dos Parques Nacionais Brasileiros, em seu Art. $6^{\circ}$, define: "Entende-se por plano de manejo o projeto dinâmico que, utilizando técnicas de planejamento ecológico, determine o zoneamento de um Parque Nacional, caracterizando cada uma das suas zonas e propondo seu desenvolvimento físico, de acordo com suas finalidades" (IBAMA,2000).

\subsection{Gestão em Parques Nacionais}

Os Parques Nacionais apresentam características específicas que potenciam uma gestão sustentável (Borrego, 1996) ${ }^{14}$ : existem, ou integram, ecossistemas e devem ser geridas como sistemas para permitirem um desenvolvimento sustentável; apresentam usos múltiplos e fornecem

\footnotetext{
${ }^{14}$ Borrego, C. (1994); "Sustainable Development of Coastal Zone: Why is it Important?", in Proceedings do Littoral 94; Associação EUROCOAST - Portugal; Lisboa; pp. 11-23
} 


\section{FOLHA DE APROVAÇÃO}

simultaneamente muitos produtos de sustentabilidade; existem ao mesmo tempo complementaridades e conflitos entre os vários usos e, para atingir um desenvolvimento ecologicamente sustentável, os conflitos têm que ser resolvidos implicando necessariamente opções; fornecem produtos aos particulares com base nos recursos existentes (que são normalmente distribuídos segundo os mecanismos de mercado), assim como produtos públicos de cujo usufruto ninguém pode ser excluído (esta não exclusão pode originar uma sobre-utilização de um dado recurso e fazer perigar a sua sustentabilidade); por fim, podem ser geridas por privados ou por entidades públicas havendo que coordenar este tipo de situação.

A gestão em Parques Nacionais é habitualmente abordada "em cima dos acontecimentos", isto é, fundamentalmente numa resposta imediata aos problemas graves de degradação ambiental destas áreas; aumentando apreciavelmente as potencialidades da área; ou segundo o entendimento de que os Parques Nacionais constituem sistemas dinâmicos entre processos físicos, químicos, biológicos e socioeconômicos.

A gestão em Parques Nacionais somente poderá ser implementada com a participação dos cidadãos, principalmente da comunidade local. Outros atores sociais também devem participar dessa gestão como: ONG's, associações, sindicatos, empresários, institutos de pesquisa, órgãos públicos, entre outros.

As parcerias entre instâncias de governo e entre os mais diversos segmentos da sociedade aparecem como resultado de um processo em que todos contribuem para garantir o uso e a conservação do patrimônio natural do país.

Segundo Salgado ${ }^{15}$, as abordagens tradicionais para a gestão das áreas protegidas, principalmente de Parques Nacionais, geralmente são desarmônicas e constrangedoras para a comunidade local, reprimindo-as com

\footnotetext{
${ }^{15}$ SALGADO, G. S. M. Economia e Gestão de Áreas Protegidas: o caso do Parque Nacional de Brasília. Brasília, 2000, 124 p. Dissertação (Mestrado em Gestão Econômica do Meio Ambiente), Universidade de Brasília - UnB, Instituto de Ciências Humanas, Departamento de Economia.
} 


\section{FOLHA DE APROVAÇÃO}

a proteção de guardas e de penalidades. De fato, a gestão de Parques Nacionais tem enfatizado o papel policial visando o cerceamento e a exclusão da população local - ou seja, cercar e multar. Com isso, geram-se conflitos sociais e econômicos que surgem ao longo dos limites das áreas e assim, a consciência popular e o apoio político para os programas de gestão das áreas protegidas diminuem.

No Parque Nacional da Chapada dos Veadeiros - GO, utiliza-se com sucesso a estratégia do processo participativo com a comunidade, promovendo a aproximação e a coordenação entre os administradores da área, as autoridades regionais e a sociedade em geral, integrando-os nos processos de solução de conflitos, denominada "aproximação orientada à comunidade". De acordo com Oviedo $(1992)^{16}$, a origem desse processo relaciona-se com o surgimento de uma nova corrente de pensamento, na década de 70 , que enfatizava a promoção do poder das pessoas, envolvendo-as nas tomadas de decisão para torná-las participantes da gestão de seu próprio progresso, o que foi estendido à gestão ambiental.

Por gestão ambiental entende-se o conjunto de princípios, estratégias e diretrizes de ações e procedimentos para proteger a integridade dos meios físico e biótico, bem como a dos grupos sociais que deles dependem. Esse conceito inclui, também, o monitoramento e o controle de elementos essenciais à qualidade de vida, em geral, e a salubridade humana, em especial. Suas atividades envolvem o monitoramento, o controle e a fiscalização do uso dos recursos naturais, bem como o processo de estudo, avaliação e eventual licenciamento de atividades potencialmente poluidoras. Envolve, também, a normatização de atividades, definição de parâmetros físicos, biológicos e químicos dos elementos naturais a serem monitorados, assim como os limites de sua exploração e/ou as condições de atendimento dos requerimentos ambientais em geral. (MMA/FUNATURA,2000) ${ }^{17}$

\footnotetext{
16 OVIEDO, G. Áreas Protegidas y Comunidades Locales. Artigo baseado na ponencia presentada no IV Congresso Mundial de Áreas Protegidas e o resultado das deliverações do sub-grupo2, ofician I.1. Fundación Natura, 1992.

${ }^{17}$ Gestão dos Recursos Naturais, subsídios a elaboração da Agenda 21 brasileira. MMA Ministério do Meio Ambiente, Instituto Brasileiro do Meio Ambiente e Recursos Naturais Renováveis, Consorcio TC/BR/FUNATURA,2000.
} 


\section{FOLHA DE APROVAÇÃO}

Os Parques Nacionais podem gerar rendimentos significativos, e assim contribuir de forma importante para as economias locais. Assim, o investimento em Parques Nacionais pode prover de benefícios expressivos para as economias locais e mesmo nacionais. A questão é se identificar os bens e serviços, ou produtos, que os Parques Nacionais oferecem, e que são adequados para a obtenção de renda para as mesmas. Com uma administração apropriada, o produto em "oferta" pode ser vendido continuamente sem que se diminua o valor respectivo, sendo que a renda pode ser utilizada para a manutenção do Parque Nacional. Alternativas inovadoras em relação às fontes tradicionais de manutenção dos Parques Nacionais são necessárias, principalmente para assegurar a sua viabilidade e existência em longo prazo.

São várias as exigências a ter em conta na gestão de Parques Nacionais: uma visão nacional; uma visão de longo prazo; uma abordagem integrada de ordenamento do território e de gestão; comunicação, colaboração e coordenação entre os diversos responsáveis pelo ordenamento, gestão e utilizadores; envolvimento público; flexibilidade; e instituição específica.

O debate sobre a gestão de Parques Nacionais no Brasil é usualmente colocado em termos de se tentar alcançar o equilíbrio deixando as áreas protegidas em seu estado natural, ou desenvolvê-las e explorá-las. O modelo tradicional de gestão, que tenta isolar os Parques Nacionais e áreas protegidas da influência humana e do contexto social e econômico que os rodeiam, só tem gerado conflitos, resistências locais. Do outro lado do modelo tradicional existem propostas alternativas. O modelo alternativo tem como característica fundamental à participação de todos os setores afetados ou interessados na criação e na gestão de um Parque Nacional, especialmente as comunidades locais. As comunidades locais participam, desde o início, da criação da unidade e têm poder de fato para intervir na sua gestão. Também no que diz respeito à gestão dos Parques Nacionais é fundamental existirem mecanismos com o propósito de assegurar a participação das comunidades locais. (Salgado,2000). 


\section{FOLHA DE APROVAÇÃO}

\subsection{Participação Local}

Através do processo participativo, as comunidades e os conservacionistas podem harmonizar suas diferenças e se tornarem aliados, cooperando em direção ao alcance do objetivo comum de se proteger os recursos naturais, através da conscientização.

A melhor proteção de uma Unidade de Conservação é constituída pela compreensão das populações locais e da sociedade em geral. Neste caso, segundo Cases $(1995)^{18}$, o elemento central da estratégia é um programa de Educação Ambiental, que permitirá à comunidade local compreender os benefícios indiretos e diretos produzidos pela Unidade de Conservação e, dessa forma, garantir seu apoio. Destaca-se a importância de que os programas de Educação Ambiental sejam apropriados à realidade da área.

A Educação ambiental é de suma importância na conscientização da comunidade no que diz respeito à conservação da natureza, fazendo com que cada indivíduo conheça o seu próprio meio, seus elementos, suas interações e a importância de sua preservação, contribuindo para a melhoria significativa da qualidade de vida da região.

A participação local deve ser reconhecida e estimulada, não só por ser um direito básico da sociedade, mas porque é uma peça fundamental no processo de gestão e do desenvolvimento sustentável.

É essencial estabelecer mecanismos que permitam essa participação, desde a definição do objeto da gestão até a execução das atividades de monitoramento e fiscalização, passando pelos processos de licenciamento e pelos critérios e limites a serem adotados. $O$ respeito aos anseios dos usuários é a condição básica para garantir o processo participativo. Somente se tornam co-responsáveis no processo de gestão aqueles que tiverem reconhecidas e respeitadas suas experiências, seus interesses, suas opiniões. (MMA/FUNATURA,2000).

\footnotetext{
${ }^{18}$ CASES, Olatz. Documento de Informações Básicas sobre as principais Correntes Filosóficas e Conceituais de Conservação das Áreas Protegidas, com ênfase para América Latina. IBAMA/DIREC/DEUC, Brasília, 1995, 66p.
} 


\section{FOLHA DE APROVAÇÃO}

Em geral, a participação da comunidade local é vista como uma ferramenta estratégica para reduzir os conflitos por meio da pacificação das comunidades locais. Sua aplicação em Parques Nacionais pode ser obtida, através da informação às comunidades locais acerca de questões e decisões relevantes; de consultas freqüentes às comunidades locais sobre questões e decisões diversas; da busca do consenso nas questões e decisões; da negociação aberta com as comunidades locais para se alcançar o entendimento em questões específicas e assim efetivamente envolvendo-as no processo de tomada de decisão e na divisão com as comunidades da autoridade e responsabilidade (Salgado, 2000).

Assim, o processo de aproximação concreta entre os administradores e gestores de Parques Nacionais, a comunidade local e os ambientalistas deve ser implementado, minimizando-se o conflito existente de que conservação é incompatível com o desenvolvimento. (Figueiredo, 1997) ${ }^{19}$.

\subsection{Arrecadação e Concessões}

Uma ação identificada como necessária para a melhoria da gestão nos parques públicos é o fortalecimento dos setores relacionados ao patrimônio e à arrecadação de receitas próprias. A Ciset/MMA (Secretaria Federal de Controle Interno/ Ministério do Meio Ambiente) constatou situações envolvendo subutilização do potencial de arrecadação, áreas ocupadas irregularmente e contratos de baixo retorno à administração pública, que indicam a urgência de reestruturação desse setor.

${ }^{19}$ FIGUEIREDO, L. A. V. Ecoturismo e participação popular no manejo de áreas protegidas: aspectos conceituais, educativos e reflexões. In Adyr Balastreri Rodrigues (org.) "Turismo e Ambiente - Reflexões e Propostas". Hucitec, São Paulo, 1997,177p. 


\section{PARQUE NACIONAL DE BRASÍLIA}

\subsection{Antecedentes Legais}

A criação do PNB está diretamente relacionada com a construção de Brasília, quando foi feito um acordo entre o Ministério da Agricultura e a NOVACAP que mantinha, em parte da área, um viveiro destinado a arborização da nova capital (IBDF/FBCN,1979) ${ }^{20}$.

O Primeiro-Ministro Tancredo Neves criou, em $1961^{21}$, o PNB, dando partida ao processo de criação de uma série de Unidades de Conservação no Distrito Federal.

Os seus 30.566 hectares contribuem, para a promoção da qualidade vida do Distrito Federal, por meio dos serviços ecossistêmicos prestados e pelas oportunidades de lazer e educação ambiental que oferece.

O PNB é de extrema importância na preservação da qualidade do lago artificial de Santa Maria, lá situado, que abastece parte do Distrito Federal, além de garantir a qualidade da água de dois importantes contribuintes do Lago Paranoá, os córregos Torto e Bananal.

\footnotetext{
${ }^{20}$ IBDF - Instituto Brasileiro de Desenvolvimento Florestal / FBCN - Fundação Brasileira para Conservação da Natureza, Plano de Manejo do Parque Nacional de Brasília, 1979, 52p.

${ }^{21}$ Decreto federal $n^{\circ} 241$, de 29 de novembro de 1961
} 


\section{FOLHA DE APROVAÇÃO}

Apesar de ser um parque urbano e estar submetido a várias pressões antrópicas nos seus $72 \mathrm{Km}$ de perímetro e em seu interior, abriga áreas com elementos representativos da flora e fauna do Bioma Cerrado, ainda em admirável grau de preservação.

\subsection{Histórico}

O Cerrado é uma grande concentração de formas vegetais, considerados pelos biólogos um berço da fauna planetária. Durante o ciclo do ouro, as extrações feitas na região de Pirenópolis eram transportadas para o litoral baiano passando pelo interior do PNB, onde havia a "contagem", hoje nome dado à chapada existente no mesmo.

O PNB surgiu no contexto da construção da cidade de Brasília como nova capital do Brasil, na década de 60. Sua origem se deu em um convênio mantido entre o Ministério da Agricultura e a NOVACAP - Companhia de Desenvolvimento da Nova Capital, que propunha a criar novas reservas e postos florestais no Distrito Federal. Em 1960, estando o convênio prestes a terminar, e se entendendo que uma área denominada Fazenda Bananal, faixa de terra entre os córregos do Acampamento e Bananal, e as cabeceiras dos córregos Rego e Capão Comprido, justificava a criação de um Parque Nacional, então, foi feita uma exposição de motivos ao Presidente da República, que deu origem ao PNB.

Da exposição de motivos destacavam-se os seguintes objetivos específicos com a criação do PNB:

- A área é coberta por flora típica do cerrado, formação vegetal que ocupa mais de 1,5 milhões de km2 do Território Nacional, ou seja, mais da sua sexta parte, localizando-se Brasília no centro deste tipo de vegetação; 


\section{FOLHA DE APROVAÇÃO}

- A área é rica em fauna típica da região, e são necessárias providências para que esta permaneça intacta;

- A topografia possui acidentes "sui generis" somente ali verificados, como nascentes de águas cristalinas, penhascos de arenito, fenômenos de "karst" etc., que devem ser protegidos;

- A área inclui as bacias dos três rios fornecedores de água potável da Capital. Trata-se, portanto de conseguir o domínio efetivo sobre as áreas destes mananciais e colocá-las à guarda de um organismo - o Parque Nacional de Brasília;

- A manutenção desta área em estado natural contribuiria também para o equilíbrio das condições climáticas e evitar-se-ia a erosão do solo;

- A área serviria como instituição educacional destinada a educar o povo nas práticas conservacionistas e servir para estudos e pesquisas.

Os 30.566 hectares do Parque, que se encontram totalmente cercados e sob a administração do IBAMA, protegem uma importante amostra do cerrado.

Cabe ressaltar o pioneirismo da ação de criar o PNB, dado que até meados de 1978 não existia, por parte do Estado brasileiro, uma estratégia nacional para selecionar e formar Unidades de Conservação.

\subsection{Localização, limites e vias de acesso.}

O PNB localiza-se na região nordeste do Distrito Federal, a $10 \mathrm{~km}$ do centro de Brasília. Para chegar até lá, a partir do Plano-Piloto de Brasília, devese seguir pela Estrada Parque de Indústria e Abastecimento (EPIA - BR-040), passando pelo Setor Militar Urbano, $9 \mathrm{~km}$.

O PNB tem como limites ${ }^{22}$ :

\footnotetext{
${ }^{22}$ O Decreto $n^{\circ} 241 / 61$, em seu art. $2^{\circ}$.
} 


\section{FOLHA DE APROVAÇÃO}

- Ao norte, a Estrada Parque Contorno - EPCT (DF-001);

- A nordeste, a Estrada Parque Contorno - EPCT (DF-001);

- A leste, a Estrada Parque Indústria e Abastecimento - EPIA (DF-003) e a Estrada Parque Contorno - EPCT (DF-001);

- Ao sul, o Córrego Acampamento;

- A sudoeste, a Estrada Parque Acampamento - EPAC (DF-097);

- A oeste, a Estrada Parque Contorno - EPCT (DF-001).

- A noroeste, a Estrada Parque Contorno - EPCT (DF-001).

O PNB também se limita com as Regiões Administrativas do Cruzeiro, Guará, Taguatinga, Brazlândia e Sobradinho. Pelo Macrozoneamento do Distrito Federal, definido no Plano Diretor de Ordenamento Territorial - $\mathrm{PDOT}^{23}$, o PNB é identificado como Zona de Conservação Ambiental e circundado, numa maior extensão, por uma Zona Rural de Uso Controlado. Em uma faixa voltada para o Lago Norte faz limite com a Zona Urbana de Uso Controlado, e, na porção voltada para o Cruzeiro, Guará e Taguatinga, com uma Zona Urbana de Dinamização.

Na Reserva da Biosfera do Cerrado ${ }^{24}$, o PNB é considerado Zona Nuclear, e envolvido por uma Zona Tampão e por uma Zona de Transição.

\subsection{Análise da vegetação/Cerrado}

O PNB situa-se nas coordenadas $15^{\circ} 35^{\prime}$ - $15^{\circ} 45^{\prime}$ S e $47^{\circ} 53^{\prime}-48^{\circ} 05^{\prime} \mathrm{W}$ (Ramos, 1995) ${ }^{25}$,como o clima da região é tropical, semi-úmido, com temperatura média anual de $21^{\circ} \mathrm{C}$, possui a vegetação do Cerrado, que se caracteriza por diferentes paisagens, que vão desde o cerradão (com árvores altas, densidade maior e composição distinta), passando pelo cerrado mais comum no Brasil central (com árvores baixas e esparsas), até o campo

\footnotetext{
${ }^{23}$ Lei Complementar $n^{\circ} 17$, de 28 de janeiro de 1997.

${ }^{24}$ Lei distrital $n^{\circ} 742$, de 1994.

${ }^{25}$ RAMOS. P. C. M., 1995. Vegetation communities and soils in the National Park of Brasília. Ph.D. thesis. Department of Geography, University of Edinburgh. Edinburgh.
} 


\section{FOLHA DE APROVAÇÃO}

cerrado, campo sujo e campo limpo (com progressiva redução da densidade arbórea).

Ao longo dos córregos estão as matas de galeria, que são florestas com cobertura arbórea entre $70-95 \%$ e altura média variando entre 20 a 30 m. As matas de galeria do PNB foram estudadas por Felfili et al.(1994) ${ }^{26}$, Ramos (1995) e Walter (1999) ${ }^{27}$. Ramos (1995) estudou sete matas de galeria, quais sejam Barriguda, Capão Comprido, Cemave, Cristal, Palmas, Piscina e Três Barras. Walter (1999) estudou a mata do Córrego Acampamento. Essas matas ocorrem em solos bem drenados, com exceção da mata Acampamento e Três Barras, que ocorrem em solos inundados, mesmo na estação seca. Juntas, apresentam uma grande diversidade de espécies arbóreas, destacando-se o babaçu (Attalea speciosa), que na mata Palmas forma um sub-bosque sempre-verde, com cobertura de 15 a $20 \mathrm{~m}$ de altura, angico (Anadenanthera colubrina), canela-de-velho (Aspidosperma subincanum), landim (Calophyllum brasiliense), jequitibárosa (Cariniana estrellensis), louro (Cryptocaria aeschersoniana), ingá (Inga marginata), milho torrado (Maprounea guianensis), bálsamo (Myroxylon peruiferum), e canelas (Nectandra cissiflora, N. gardnerii, Ocotea aciphylla, O. spixiana), amescla (Protium heptaphyllum) (IBDF/FBCN, 1979).

Considerado como um tipo de savana, o Cerrado ocorre nas áreas de interflúvio e é caracterizado pela presença de uma camada de árvores distribuídas sobre um estrato herbáceo-subarbustivo, com predominância de gramíneas. O cerrado ocorre em diversas densidades arbóreas, desde fisionomias mais densas até fisionomias mais abertas. As árvores são de pequeno porte, geralmente tortuosas e de casca grossa. As principais espécies são pequi (Caryocar brasiliense), carvoeiro (Sclerolobium paniculatum), pau-santo (Kielmeyera coriacea), jacarandá-do-campo

\footnotetext{
${ }^{26}$ FELFILI, J. M., SILVA JÚNIOR. M. C., REZENDE, A. V., MACHADO, J. W. B.,WALTER, B. M. T. \& SILVA, P. E. N. 1994. Vegetação Arbórea. In Felfili et. al.(eds), Projeto Biogeografia do Bioma Cerrado - Vegetação e Solos. Caderno de Geociências do IBGE 12: pp. 75-166.

${ }^{27}$ WALTER, B. M. T.; SAMPAIO, A. B.; GUARINO, E. S. G.; CORDOVIL-SILVA, S. P.; SANTOS, A. A.; PEREIRA, J. B. 1999. Fitossociologia de um trecho de mata de galeria inundável no Parque Nacional de Brasília, DF. In: $50^{\circ}$ Congresso Nacional de Botânica, Blumenau. Resumos. Blumenau, SC. 1999. p.273
} 


\section{FOLHA DE APROVAÇÃO}

(Machaerium opacum) e jacarandá-do-cerrado (Dalbergia miscolobium). No estrato herbáceo-arbustivo ocorrem gramíneas, como o capim-flexinha (Echinolaena inflexa), capim rabo-de-raposa (Aristida sp.), Tristachya leiostachya, ciperáceas (Bulbostylis paradoxa, Rhynchospora spp.), iridáceas (Trimezia sp., Syzirinchium sp.) e latifoliadas, como Vernonia spp., Pavonia sp. e cajuí (Anacardium humile), Mandevilla illustris, entre outras.

Os campos são formações vegetacionais caracterizadas pelo estrato herbáceo-subarbustivo bem desenvolvido e presença rara de arbustos ou arvoretas. Dominam essas fisionomias espécies de gramíneas e ciperáceas. No PNB ocorre em grande quantidade à gramínea exótica e invasora, capim gordura (Mellinis minutiflora). Nos locais onde o campo torna-se encharcado aparecem buritis (Mauritia flexuosa), formando pequenas veredas.

Estima-se que a flora da região possua 10 mil espécies de plantas diferentes (muitas usadas na produção de cortiça, fibras, óleos, artesanato, além do uso medicinal e alimentício). Dentre as plantas as que mais se destacam são: o jacarandá-do-mato, o pequizeiro, o buriti, a guariroba e os ipês roxo e amarelo. Contudo, o PNB também abriga espécies raras, como a da orquídea Comparettia coccinea, e a Cattleya bicolor, que é muito procurada por orquidófilos profissionais e amadores.

Muitas das plantas encontradas no PNB são potencialmente ornamentais, como a esponjinha do cerrado, prá-tudo, sempre-viva, assapeixe, entre várias outras espécies arbustivas e outras tantas arbóreas. Além disso, muitas plantas nativas do cerrado, e abrigadas pelo PNB, são utilizadas de alguma forma por elementos da fauna como alimento.

\subsection{Análise da fauna}

Encontram-se no Cerrado 759 espécies de aves que se reproduzem na região, 180 espécies de répteis, 195 de mamíferos, sendo 30 tipos de morcegos catalogados na área. $\mathrm{O}$ número de insetos é surpreendente: apenas 


\section{FOLHA DE APROVAÇÃO}

na área do Distrito Federal há 90 espécies de cupins, mil espécies de borboletas e 500 tipos diferentes de abelhas e vespas.

O PNB abriga uma fauna bastante rica. Um grande número de animais do Cerrado já encontrou abrigo seguro na área do Parque, com exceção de grandes mamíferos predadores, que por necessitarem de áreas territoriais mais extensas não encontram condições adequadas de subsistência.

Alguns dos grandes mamíferos já ameaçados de extinção são: o veado campeiro, o lobo-guará, o tamanduá bandeira, o tatu canastra.

Entre as espécies não ameaçadas de extinção pode-se observar no PNB a anta, caitetu, queixada, capivara, sagüi, tapeti, cachorro-do-mato, coati e várias espécies de tatu. Mesmo espécies ameaçadas de extinção já foram encontradas, como o lobo-guará, veado campeiro, tatus-canastra e bola, e o tamanduá-bandeira.

Igualmente rica é a avifauna ${ }^{28}$, onde se destacam as espetaculares emas, a seriema, a perdiz, a codorna, o tucano, os papagaios, rapinantes de grande porte como o cará-cará e os urubus.

No lago da Anta, situado no interior do Parque Nacional, pode-se ainda ser observado numerosas aves aquáticas como a marreca, diversas espécies de garças, o biguá, o biguátinga e o colhereiro rosado.

Já a ictiofauna é composta de peixes de pequeno porte, sendo comuns os lambaris, carás e piaus.

A herpetofauna do PNB também é representativa, contando inclusive com o maior dos nossos répteis, a sucuri. Ocorrem, na qualidade de ofídios peçonhentos, quatro espécies de jararacas, cascavel e uma coral verdadeira. Vários lagartos, lagartixas e cobras não venenosas são encontrados, merecendo destaque a boipeva ou capitão do mato, e o teiu, conhecido pelo seu porte majestoso. Também se encontram jacarés do gênero Caiman.

\footnotetext{
${ }^{28}$ A área da piscina velha, na Zona de Uso Intensivo do PNB, é considerada o melhor local de todo o Distrito Federal para se observar aves de matas ciliares (IBAMA \& FUNATURA, 1998).
} 


\section{FOLHA DE APROVAÇÃO}

\subsection{Recursos Hídricos/Hidrologia}

As águas do PNB, por sua qualidade e abundância (dezenas de nascentes), são de importância estratégica para o Distrito Federal, pois ele fornece aproximadamente $30 \%$ da água que abastece a população de Brasília e oferece aos visitantes piscinas de água mineral corrente e áreas de lazer.

A área do Parque engloba como bacias hidrográficas principais às dos rios Torto e Bananal, subsidiários do rio Paranoá, que são formadoras da Barragem de Santa Maria, que abastece de água potável parte da Capital Federal. A bacia hidrológica do Parque pode ser englobada na categoria de drenagem "dentrítica", ou "arborescente". A bacia do Torto tem uma área aproximada de 20.530 hectares e uma descarga média de $3,10 \mathrm{~m}^{3} / \mathrm{s}$. Já a bacia do Bananal, com aproximadamente 10.870 hectares de área, possui uma descarga média de 2,20 m³. A barragem de Santa Maria ocupa uma área de $8,25 \mathrm{~km}^{2}$, correspondendo a um volume de armazenamento de 8.000 .000 de $\mathrm{m}^{3}$ e uma vazão de $2,8 \mathrm{~m}^{3} / \mathrm{s}$. Nos últimos dez anos é captado uma média de $1,86 \mathrm{~m}^{3} / \mathrm{s}$ (IBDF/ FBCN, 1979) (IBAMA /FUNATURA, 1998) ${ }^{29}$.

Além da abundância de água ocorrem dois fenômenos muito interessantes: o primeiro, conhecido como Peito-de-Moça um dos aspectos hidrológicos mais significativos do Parque, que é uma fonte, chamada "de contato", não ligada ao lençol freático, sendo por isso pouco freqüente de ser encontrada. Essas fontes têm origem no contato de rochas permeáveis com impermeáveis, provocando escoamento lateral das águas até o ponto onde emergem. As cotas onde elas aparecem são muito variáveis, dependendo da inclinação, do contato e da espessura das rochas permeáveis. Na fonte "Peito de Moça", que retrata esse fenômeno, a água brota com vazão de cerca de três litros por segundo, do topo de uma elevação argilosa em forma de calota esférica, com cerca de 2,50 metros de altura por 6 metros de diâmetro. A vazão

\footnotetext{
29 IBAMA - Instituto Brasileiro do Meio Ambiente e dos Recursos Naturais Renováveis /
} FUNATURA - Fundação Pró-Natureza. Plano de Manejo do Parque Nacional de Brasília,1998. 


\section{FOLHA DE APROVAÇÃO}

do Peito de Moça varia em função da distribuição anual das chuvas. Porém, mesmo nos períodos mais secos, a vazão é superior a 7.000 litros por hora.

O outro fenômeno conhecido como Quatro Buracos, (ou "Cinco Buracos") $)^{30}$. É uma estrutura representada por quatro (ou cinco) buracos dispostos, linearmente, tendo no subsolo a presença de água e aflorando em alguns pontos, correndo pelo fundo e sumindo e, logo adiante, ressurgindo no buraco seguinte, situadas na porção SW do PNB, possuem em seu interior e nos limites internos uma vegetação exuberante, do mesmo porte de uma mata ciliar, e são interligados por um intenso fluxo subterrâneo perene, cujo volume estimado alcança valores superiores a 10.000 litros por hora.

\subsection{Problemas enfrentados pelo PNB}

O PNB é uma das maiores áreas de Cerrado preservado. Porém, por se localizar em área urbana, sofre sérios impactos em seu entorno, o que vem prejudicando a sua biodiversidade. A invasão da Estrutural, maior do DF, com aproximadamente 25 mil pessoas, e o Aterro Controlado ("lixão"), são os maiores impactos (ENEB,2002) $)^{31}$.

O "Lixão da Estrutural" está situado na margem direita da Estrada Parque Ceilândia - EPCL (DF 095), próximo à cabeceira do Córrego Vicente Pires, separado do Parque apenas pela Estrada Parque Acampamento - EPAC (DF 097). Este depósito irregular de lixo recebe resíduos sólidos industriais, domésticos e hospitalares, funcionando no local há cerca de 30 anos. São depositados no local cerca de 1400 toneladas/dia de lixo, numa área de aproximadamente 175 hectares. O depósito de lixo não possui medidas de proteção ambiental adequadas, não se utilizando técnicas que evitem impactos mais significativos, como a impermeabilização das valas, drenagem do gás e chorume, tratamento do percolado. O "lixão", como é mais conhecido, apesar de todos os problemas que causa, e de ser uma atividade não licenciada do ponto de vista ambiental, continua funcionando regularmente. (Salgado, 2000).

\footnotetext{
${ }^{30}$ Segundo entrevista com o Interprete Ambiental do PNB Neilton Rodrigues, já são cinco buracos.

${ }^{31}$ ENEB - Encontro Nacional de Estudantes de Biologia/UnB. Envolvimento Sustentável Vivenciar para Atuar. Brasília, 2002.
} 


\section{FOLHA DE APROVAÇÃO}

A proximidade do depósito de lixo com o PNB traz uma série de problemas, como:

- a decomposição do lixo fornece alimento a animais, causando um aumento desproporcional nas populações. Assim, o crescimento das populações de cães, ratos, urubus, é significativo, o que traz problemas para a fauna do PNB, já que os animais invadem o Parque para caça, e acabam se tornando selvagens. A área do lixão é o maior foco de invasão de cães no PNB, sendo os maiores causadores da mortalidade da fauna silvestre, seja pela predação, competição ou com a introdução de doenças diversas;

- o lixão constitui-se numa fonte potencial de contaminação das águas superficiais

e subterrâneas, além de representar um foco de acidentes devido à presença de gases inflamáveis produzidos pelos dejetos. Dados geofísicos de sondagem demonstram uma pluma de contaminação oriunda do lixão em direção ao PNB, no sentido do Córrego Acampamento ${ }^{32}$

- cerca de 600 famílias sobrevivem no local, como catadores de lixo, dividindo com animais diversos os restos de comida encontrados;

- existe um impacto paisagístico negativo considerável, já que a área está totalmente degradada.

O principal problema ambiental do DF refere-se à ocupação desordenada que, em parte, é causada pela falta de planejamento e gerenciamento dos recursos terrestres. A invasão da Estrutural é um foco de problemas para o PNB. A quantidade de barracos na invasão oscila bastante. Por ocasião da elaboração da Revisão do Plano de Manejo, em 1998, existiam cerca de 2800 famílias vivendo no local. A invasão, dada a proximidade com o PNB, acentuou os problemas decorrentes da caça, pesca e queimadas.

Existe também próximo aos limites do PNB um reflorestamento de pinus e eucalipto, perfazendo um total de 802 hectares. O reflorestamento abriga

32 CARVALHO, Caio Luiz de. Na busca do Turismo que queremos. In: LAGE, Beatriz Helena Gela, MILONE, Paulo César (Org.) Turismo: Teoria e Prática - São Paulo: Atlas, 2000. 


\section{FOLHA DE APROVAÇÃO}

duas cascalheiras, uma explorada clandestinamente e a outra autorizada pelo órgão ambiental do Distrito Federal. E também foi o local escolhido pelo Governo do Distrito Federal para promover o assentamento de 130 famílias de sem-terra, assentamento esse que trouxe problemas para o PNB, inclusive com a invasão do Parque para obtenção de água.

Outro problema para o PNB é a ocupação de 126 hectares por uma fazenda agropecuária, mais conhecida como "Ocupação do Gaúcho". De acordo com o Decreto $n^{\circ}$ 241/61 essa área pertence ao PNB. A principal ocupação na área é a criação semi-extensiva de gado, com aproximadamente 80 hectares de pasto. Como o gradiente de declividade encontra-se na direção do PNB, os fertilizantes e agrotóxicos usados no preparo do solo e no combate a pragas escorrem para o Parque, ocorrendo contaminação do solo e dos recursos hídricos. Além disso, a fauna também é atingida pela ocupação, seja mediante a caça, e com a introdução de espécies exóticas, que já foram detectadas na região.

Apesar do Distrito Federal ser a unidade federativa que possui o maior percentual de seu território em unidades de conservação legalmente criadas, a área já alterada corresponde a quase $70 \%$. De acordo com o trabalho publicado pela UNESCO ${ }^{33}$, o DF perdeu, até $1998,57 \%$ de sua cobertura original. Estima-se que em 2002, esta perda aumentou para 69\% (considerando mesma taxa média de perda entre 1994 e 1998, que foi de 3\% ao ano). Este fato é gravíssimo, pois restam apenas $31 \%$ de cobertura vegetal nativa.

O mesmo documento estima que dentre as 700 espécies arbóreas e herbáceas que existiam originalmente no DF, cerca de 200 já foram extintas. Em termos de fauna a questão é, talvez, mais preocupante.

É necessário que sejam tomadas precauções adicionais com relação à preservação do entorno do Parque. Considerando as características atuais do crescimento urbano do Distrito Federal em ritmo acelerado e desordenado, o

\footnotetext{
${ }^{33}$ UNESCO - Organização das Nações Unidas para Educação, a Ciência e a Cultura. $<$ http://www.unesco.org.br>
} 


\section{FOLHA DE APROVAÇÃO}

PNB tende, com o tempo, a se tornar uma "ilha", ou seja, um ambiente natural rodeado de ambientes alterados, o que pode causar extinções de espécies e perda da biodiversidade.

\subsection{Plano de manejo do PNB}

A implementação do Plano de Manejo do PNB foi avaliada comparandose as atividades previstas no Plano com os eventos que ocorreram no Parque no decênio 1979 - 1989. De acordo com os propósitos da sua criação e a análise dos recursos, o manejo do PNB está orientado segundo os seguintes objetivos específicos:

- Conservar a flora e fauna silvestre e dos recursos genéticos do ecossistema.

- Proteger a bacia hidrográfica dos cursos de água que abastecem de água pura e saudável a Capital Federal.

- Facilitar as oportunidades para o recreio dos visitantes orientados para o conhecimento e apreciação dos seus recursos naturais.

- Contribuir para o desenvolvimento sócio-econômico do Distrito Federal, uma vez incorporado ao patrimônio turístico da Região.

\subsection{Infra-estrutura de visitação}

O PNB possui Centro de Visitantes, com torre de observação, museu, biblioteca, auditório, lanchonete, quiosques, vestiário e posto médico. Brasília, a $10 \mathrm{~km}$ do parque, possui uma excelente infra-estrutura, com hotéis e restaurantes para todos os gostos.

A unidade é aberta diariamente à visitação de 8:00 às 16:00 hs. O valor do ingresso é $\mathrm{R} \$ 3,00$ por pessoa. Por se encontrar em uma região de clima tropical o Parque pode ser visitado o ano todo, porém a melhor época é de maio a outubro. 


\section{FOLHA DE APROVAÇÃO}

O PNB é uma das principais áreas de lazer do Distrito Federal, sendo que a maior parte dos visitantes procuram refrescar-se em uma de suas duas piscinas. Existem também duas trilhas de pequena dificuldade: a da Capivara com duração de 20 minutos e a do Cristal Água cujo trajeto pode ser percorrido em 1 hora. Além disso, o Parque possui em seu interior uma pequena trilha para llha da Meditação onde se encontra, a Lagoa da Anta, local em que os visitantes podem relaxar e meditar ao som dos pássaros. O Centro de Visitantes oferece caminhadas programadas.

A pesar de possuir um Centro de visitantes muito rico em informações, sua localização não esta correta, pois encontra muito longe da entrada e da área das piscinas onde ocorre maior aglomeração de pessoas, muitos dos visitantes nem sabem que existe um Centro de Visitantes no PNB.

O Programa de Educação Ambiental que acontece no Centro de Visitantes do PNB contém estratégias diferenciadas para o seu entorno e público interno, oferece cursos de formação para professores e público geral, subsidiando-os com fundamentos teóricos e práticas interdisciplinares. Através da entrevista feita com o Intérprete Ambiental Neilton Rodrigues, os cursos são oferecidos 2 vezes por mês, possuem certificado, e auxílio de 4 professores de Universidades do DF e de outros estados. Durante o curso os alunos, também fazem as trilhas do parque.

Nas trilhas de percursos variados, são desenvolvidas atividades de senso-percepção. As suas piscinas, com água corrente são um grande atrativo para a visitação, ao lado das trilhas interpretativas e o Centro de Visitantes (14 mil visitantes/ano). O Centro de Visitantes oferece uma exposição sócioambiental; além de descritivos do Parque como seu histórico, sua flora e fauna e geologia; um acervo relativo à pressão antrópica descrevendo as conseqüências da caça predatória, do fogo criminoso, da expansão urbana irregular e da disposição de lixo e dispõe ainda de uma análise crítica da insustentabilidade e o atual modelo de "desenvolvimento". 


\section{FOLHA DE APROVAÇÃO}

O Parque conta também, com pesquisas desenvolvidas pelo Centro de Pesquisas para Conservação das Aves Silvestres (CEMAVE) $)^{34}$, órgão vinculado à Diretoria de Ecossistemas do IBAMA que têm como objetivos coordenar o sistema de anilhamento no país, analisar informações e fornecer dados técnicos necessários para a conservação de aves silvestres, bem como dos ambientes dos quais elas dependem.

A sinalização do PNB é precária, se resume em algumas placas indicativas, na estrada de acesso a trilha da Capivara, Ilha da Meditação e o Centro de Visitantes. Na área das piscinas quase não existem placas ou informações.

Existem duas guaritas no interior do Parque que dão acesso as piscinas, estas estão depredadas, e não são utilizadas da maneira correta, o guarda fica sentado do lado de fora da guarita.

A lanchonete mais antiga do Parque que fica na piscina "velha" está precisando urgente de uma reforma, sua estrutura não esta em harmonia com o Parque. As outras duas lanchonetes são mais novas, a lanchonete nova da piscina "velha" fica localizada em cima de uma nascente, podendo assim depositar resíduos na água.

O Parque necessita de mais mesas e cadeiras para lanches e repouso dos visitantes, lá quase não existem mesas e cadeiras.

O PNB possui dois estacionamentos pavimentados, um na piscina "velha" e outro na piscina "nova". Os estacionamentos comportam um número suficiente de carros.

\subsection{Gestão no PNB}

O modelo de gestão aplicado pelo IBAMA no PNB é centralizado, pois apenas o próprio órgão tem atuação e poder de decisão no que se diz respeito

${ }^{34}$ CEMAVE - Centro Nacional de Pesquisas para Conservação das Aves Silvestres - é uma unidade descentralizada do Instituto Brasileiro do Meio Ambiente e dos Recursos Naturais 


\section{FOLHA DE APROVAÇÃO}

ao Parque, e leva muito pouco em consideração os segmentos da sociedade e de outros atores interessados. Se o Parque é um bem público, ele tem que ser gerido juntamente com a comunidade.

Com isso não se tem obtido sucesso naquilo que é fundamental: fazer com que o PNB cumpra as suas finalidades ambientais, ecológicas, educativas, científicas, econômicas, culturais e recreativas, previstas em legislação.

Sabe-se que do Parque só se é utilizado pelo público apenas $0,3 \%$, que representam 137 hectares, essa área é conhecida popularmente como "Água Mineral". Com isso, 97\% da área do Parque, está cercada e sendo pouco utilizada pelo público, podendo entrar apenas pesquisadores com autorização do IBAMA. De acordo com o Plano de Manejo do PNB, existem nessa área cercada, zonas intangíveis onde a primitividade da natureza deve permanecer intacta, mas também existem zonas extensivas, onde, de acordo com o Plano de Uso Público do Parque, foram projetadas trilhas para esse local.

$\mathrm{Na}$ realidade, a adoção de uma política excludente em relação às comunidades, tem gerado conflitos e resistências sociais, econômicas e ecologicamente improdutivas, e, por conseqüência, nocivas à proteção da biodiversidade.

O apoio da comunidade local é especialmente importante para a segurança do PNB. Assim, deve-se procurar incrementar o valor das áreas protegidas, maximizando os seus benefícios e a quantidade de pessoas que delas se beneficiam - isso sem causar danos ecológicos e no mínimo custo possível. Essa mudança de postura tem sido adotada por agências ambientais pelo mundo afora, demonstrando-se que as áreas protegidas contribuem para as economias locais e para o bem-estar humano, estabelecendo-se parcerias e formas de cooperação com todos os segmentos interessados e que de alguma forma interagem com elas. 


\section{FOLHA DE APROVAÇÃO}

A comunidade local deve ser composta em sua maior parte por indivíduos que tomam decisões racionais, que têm preferências legítimas no que diz respeito à conservação da natureza. Ou seja, a comunidade local tem que ter a consciência da importância do meio ambiente que a cerca, valorizar a conservação da natureza e deve ser vista como aliada em todo o processo de gestão do Parque.

O modelo alternativo de gestão tem como característica fundamental à participação de todos os setores afetados ou interessados na criação e na gestão de um Parque Nacional, especialmente as comunidades locais. As comunidades locais participam, desde o início, da criação da unidade e têm poder de fato para intervir na sua gestão. Também no que diz respeito à gestão de Parques Nacionais é fundamental existirem mecanismos com o propósito de assegurar a participação das comunidades locais. (Borrini- Feyerabend, 1996) $)^{35}$.

Parques Nacionais e outras áreas protegidas são freqüentemente descritos como "ilhas". E essa é uma descrição bem adequada da forma como muitas das áreas protegidas têm sido geridas, como se fossem efetivamente "ilhas" isoladas do contexto regional sócio-econômico e político em que se inserem. (Zube, 1995; Freemuth, 1991) ${ }^{36}$.

Contudo, a recente elaboração do Plano de Uso Público do PNB, adotou a velha fórmula de um produto pronto, imposto de cima para baixo, com uma abordagem elitista, sem a menor participação da sociedade. Ou seja, o inverso de um processo efetivamente descentralizado e democrático ${ }^{37}$.

É necessário criar oportunidades que facilitem a comunicação entre todos os setores que têm vínculos com o PNB, permitindo ampla participação, consulta e acesso às informações.

${ }^{35}$ BORRINI-FEYERABEND, G. Collaborative Management of Protected Areas: Tailoring the Approach to the Context. IUCN Social Policy Group, 1996, 40 p.

${ }^{36}$ ZUBE, E. H. No Park is a Island. In Jeffrey McNeely (ed.) "Expanding Partnerships in Conservation", Island Press, IUCN, Washington, D.C, 1995, 302 p. \& FREEMUTH, J. C. National Parks and the Political of External Threats. University Press of Kansas, 1991, $186 \mathrm{p.}$

${ }^{37}$ SALGADO, G.S. M. Artigo Público, mas sem público, Gazeta Mercantil, 15 de outubro de 2001. 


\section{FOLHA DE APROVAÇÃO}

O Plano de Uso Público do PNB simplesmente ignorou o público, nenhuma das ONGs que atuam no Parque foi sequer consultada. E no PNB atuam a Patrulha Ecológica, que participa incansavelmente de todos os combates a incêndios, a Funatura, responsável pela revisão do Plano de Manejo do Parque, e a Associação Amigos do Parque, que executa atividades de educação ambiental e se engaja em todos os movimentos em prol da defesa do PNB. Isso sem falar nas inúmeras comunidades que se localizam no entorno, e que necessariamente deveriam ter sido consultadas, pois interagem de alguma forma com o Parque.

O PNB está cada vez mais isolado do contexto sócio-econômico e político do Distrito Federal. É considerado mais um problema, do que uma solução. O PNB, com toda a sua exuberância tem uma relação histórica com a nossa cidade, e um significado todo especial para Brasília, sendo um de nossos símbolos mais importantes. Além disso, pode contribuir significativamente para o fortalecimento da economia local.

Pelo fato de que no Brasil a implantação e manutenção de áreas ambientalmente protegidas não têm sido prioridade, já que a questão ambiental, de uma forma geral, fica à margem das discussões políticas e socioeconômicas, não tem sido dado o devido lugar de destaque ao PNB, apesar da importância dos diversos bens e serviços que ele pode proporcionar à sociedade. Isto se deve, em grande parte, à falta de informação sobre os benefícios do desenvolvimento em longo prazo de áreas protegidas, e também à falta de aplicação e consideração de metodologias apropriadas que sirvam para avaliar todos os benefícios que as áreas protegidas proporcionam à sociedade (IUCN, 1998). ${ }^{38}$

Não se deve confundir matéria-prima com produto turístico. O PNB é matéria prima, rica e diversificada, mas é necessário transformá-lo em "um

\footnotetext{
${ }^{38}$ IUCN - INTERNATIONAL UNION FOR CONSERVATION OF NATURE AND NATURAL RESOURCES.. Economic Values of Protected Areas - Guidelines for Protected Area Managers. IUCN, 1998, 52 p.
} 


\section{FOLHA DE APROVAÇÃO}

produto que tenha preço justo, qualidade de serviços, criatividade, identidade e principalmente diferenciais agregados" (Carvalho, 2000) $)^{\mathrm{i} 39}$.

\subsection{Oportunidades de Negócios}

O Brasil é um país com vocação natural para o Ecoturismo. Sua grande diversidade cultural e sua ampla extensão territorial propiciam uma oferta turística das mais variadas, fazendo com que o Brasil seja uma atração para os próprios brasileiros, permitindo ainda a prática da maioria das modalidades de turismo ecológico e também de esportes de aventura.

O PNB por ser uma das principais áreas de lazer, com grande potencial econômico e ambiental do Distrito Federal, pode possibilitar diversas atividades para seus visitantes como:

- Canoagem

- Centro de Visitantes

- Ciclismo

- Corridas

- Ecoturismo

- Lanchonetes

- Massagem

- Meditação

- Mirantes

- Paisagens

- Piscinas

${ }^{39}$ CARVALHO, Caio Luiz de. Na busca do Turismo que queremos. In: LAGE, Beatriz Helena Gela, MILONE, Paulo César (Org.) Turismo: Teoria e Prática - São Paulo: Atlas, 2000. 


\section{FOLHA DE APROVAÇÃO}

- Trilhas

Parte dessas atividades já existe no PNB, e outras já estão previstas, pois estão especificadas no Plano de Uso Público do Parque.

\section{PESQUISA DE VISITAÇÃO}

Foram entrevistadas 30 pessoas no PNB, do dia 05 de maio de 2003 ao dia 10 de maio de 2003.

Os questionários foram analisados, com base na análise comparativa dos Parques Nacionais, estudados quanto ao manejo de visitação, utilizados por Kinker (2002). ${ }^{40}$

\section{Origem}

\footnotetext{
${ }^{40}$ É importante afirmar que os resultados não permitem fazer generalizações, mas sim analisar tendências. p.157
} 


\section{FOLHA DE APROVAÇÃO}

Todos entrevistados são de origem brasileira, sendo que a maioria mora em Brasília, na Asa Norte. Poucos dos entrevistados moram no Cruzeiro, Guará, Lago Norte, Asa Sul, Granja do Torto, Taguatinga e Sobradinho.

\section{Gênero}

A distribuição dos visitantes por gênero não demonstra uma diferença significativa, há quase uma mesma quantidade de pessoas do sexo feminino e masculino, embora o sexo masculino seja maioria.

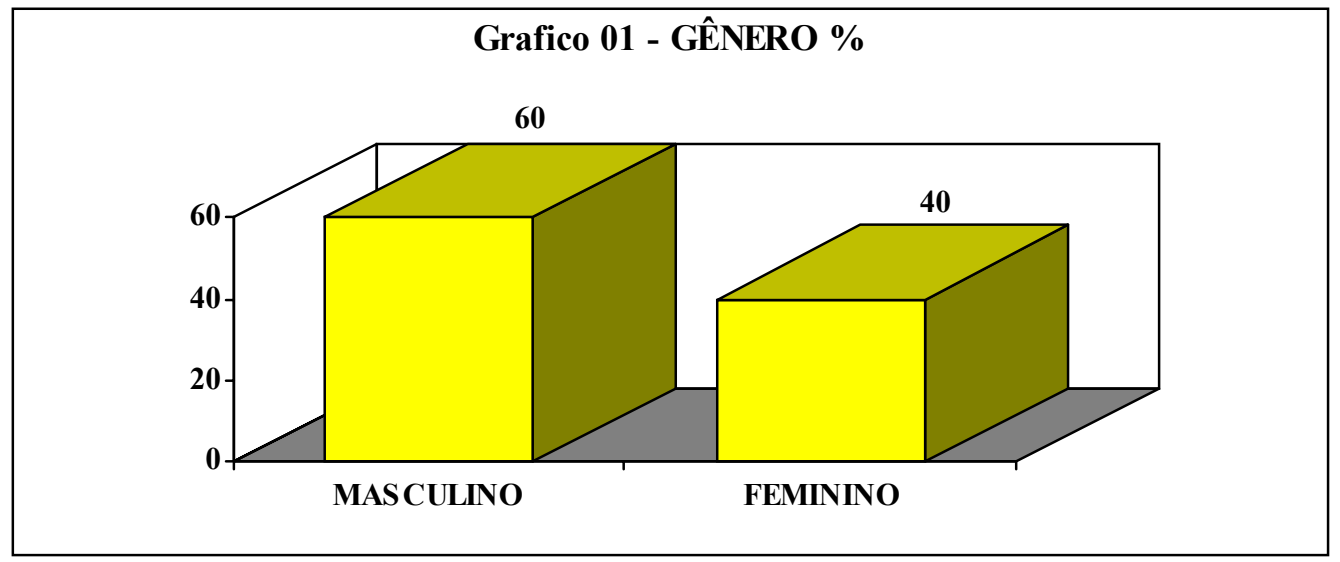

\section{Faixa etária}

A maioria dos entrevistados tem idade entre 25 a 34 anos. $O$ gráfico ilustra a distribuição por faixa etária dos visitantes entrevistados no PNB:

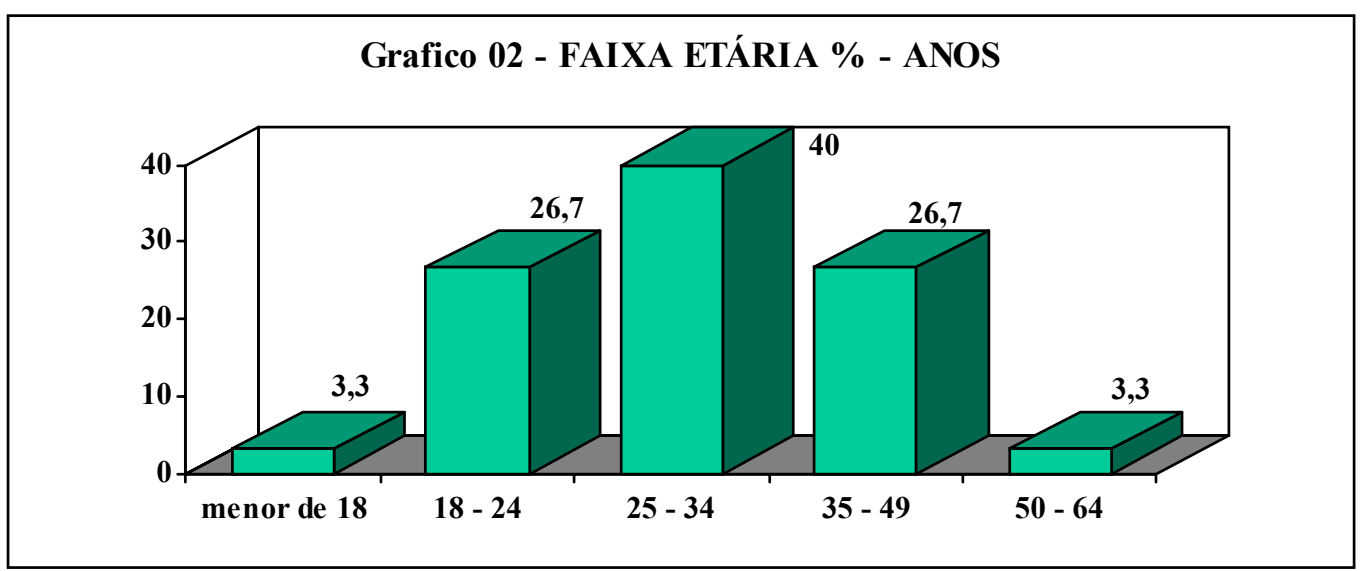




\section{Escolaridade}

Quanto à escolaridade dos visitantes, a maioria tem nível superior.

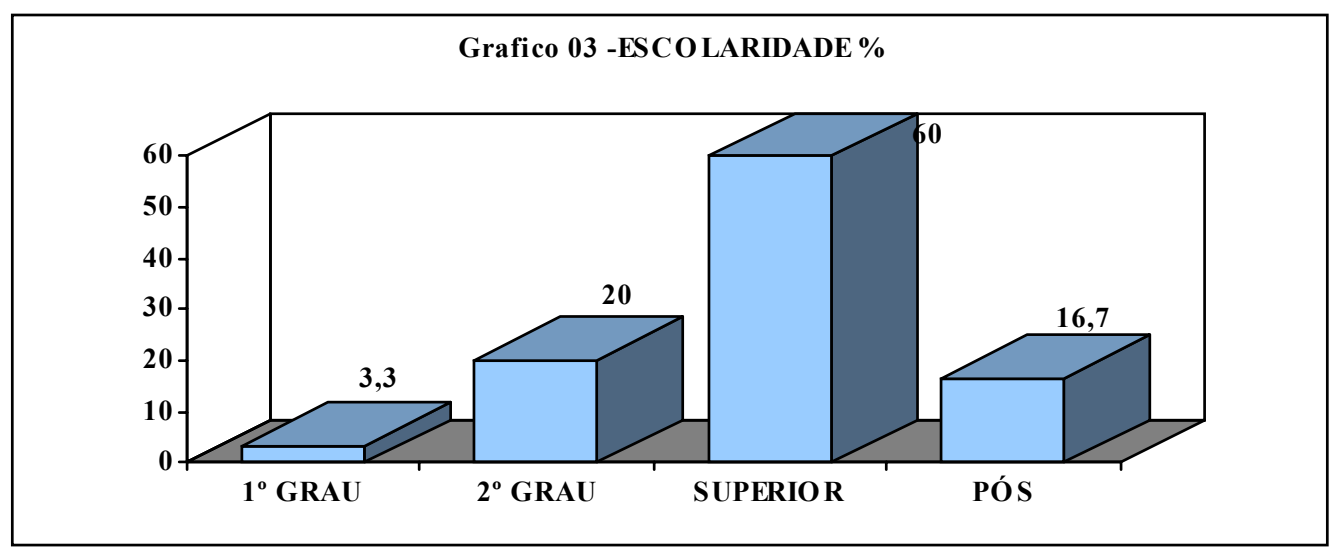

\section{Renda mensal}

A renda mensal dos visitantes entrevistados percebe-se bem variável, apesar de muitos possuírem nível superior a renda de 100 a 300 reais e de 501 a 1000 reais, esta em alta, como ilustra o gráfico abaixo:

Grafico 04 -RENDA MENSAL \% - RS

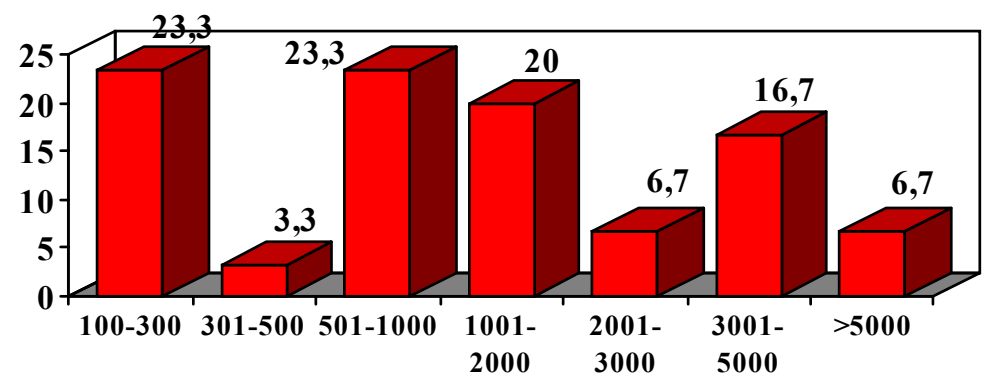




\section{Perfil do visitante que freqüenta o PNB.}

A maioria dos visitantes vão ao PNB praticar o lazer. Mas, além do lazer muitos vão praticar o corridas e natação essas três atividades são as mais desenvolvidas no Parque. Além dessas, uma minoria pratica ginástica e caminhadas.

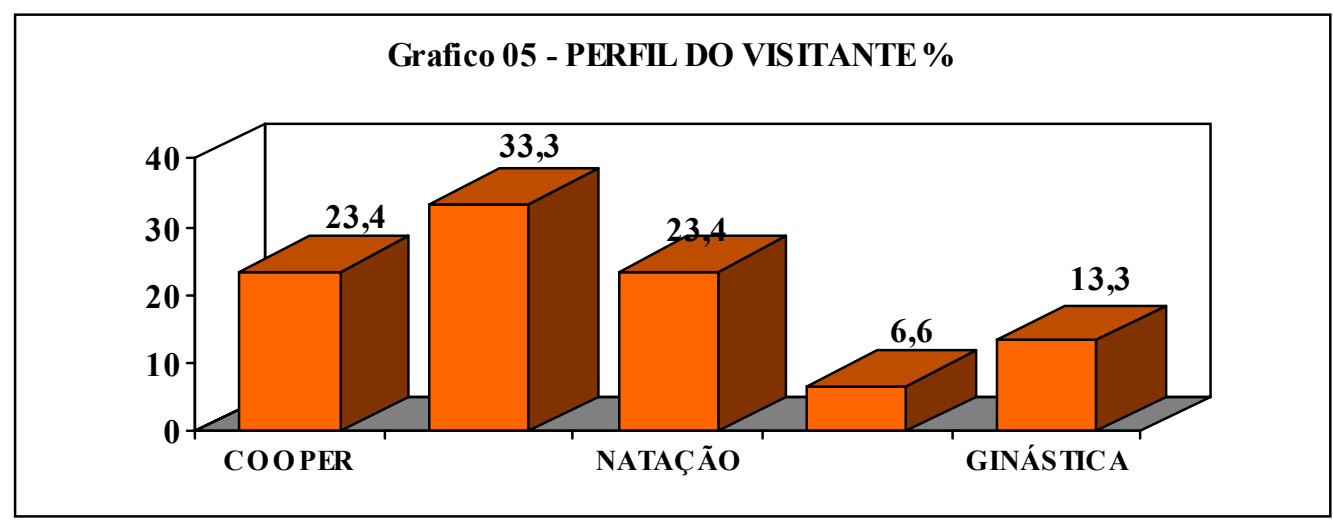

Há quanto tempo freqüenta o Parque?

A maioria dos entrevistados freqüenta o Parque há pouco tempo na média de 0 a 5 anos, porém 23,4\% freqüentam a mais de 16 anos. Conforme ilustra o gráfico abaixo:

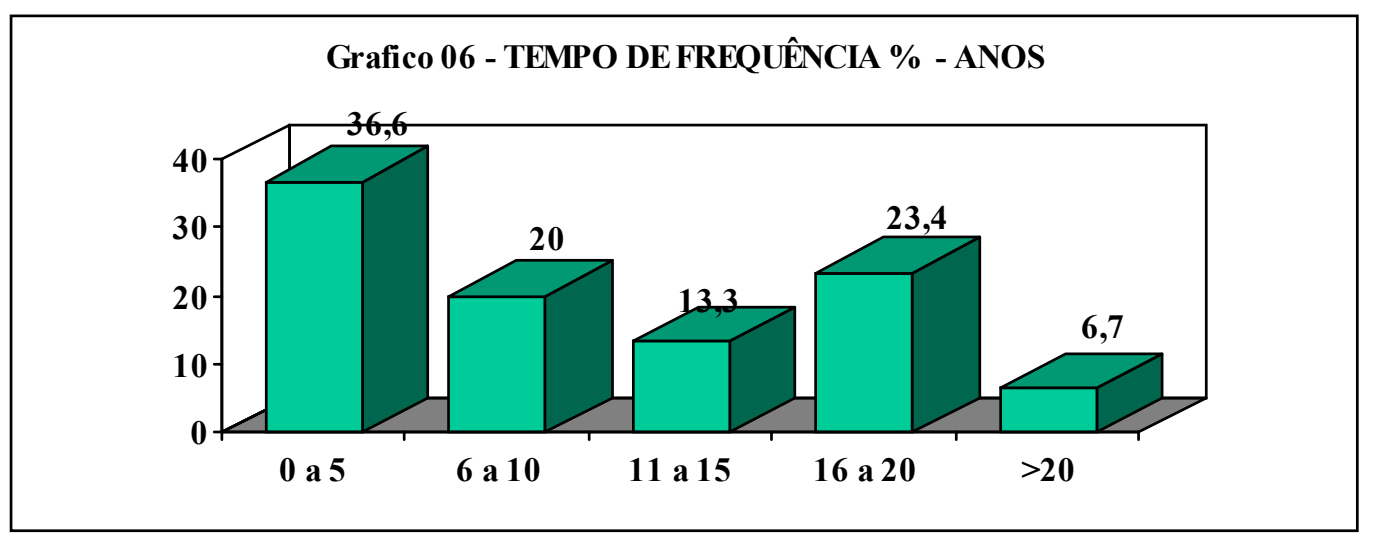




\section{Conheceu o Centro de Visitantes?}

O Centro de Visitantes é o local utilizado para recepcionar os visitantes, onde são transmitidas informações por meio de folhetos, vídeos, slides, palestras e exposições de fotos, como o objetivo de fazer com que a visita seja mais bem aproveitada, aprendendo sobre o ambiente visitado e sobre como causar mínimo impacto.

O PNB tem um Centro de Visitantes, porém $50 \%$ das pessoas entrevistadas não o conhecem ou nem sabe da sua existência. Isso acontece por conta da sua localização, que é muito longe da área de lazer, fazendo com que as pessoas não vão até ele. $O$ correto seria um Centro de Visitantes logo no entrada do Parque.

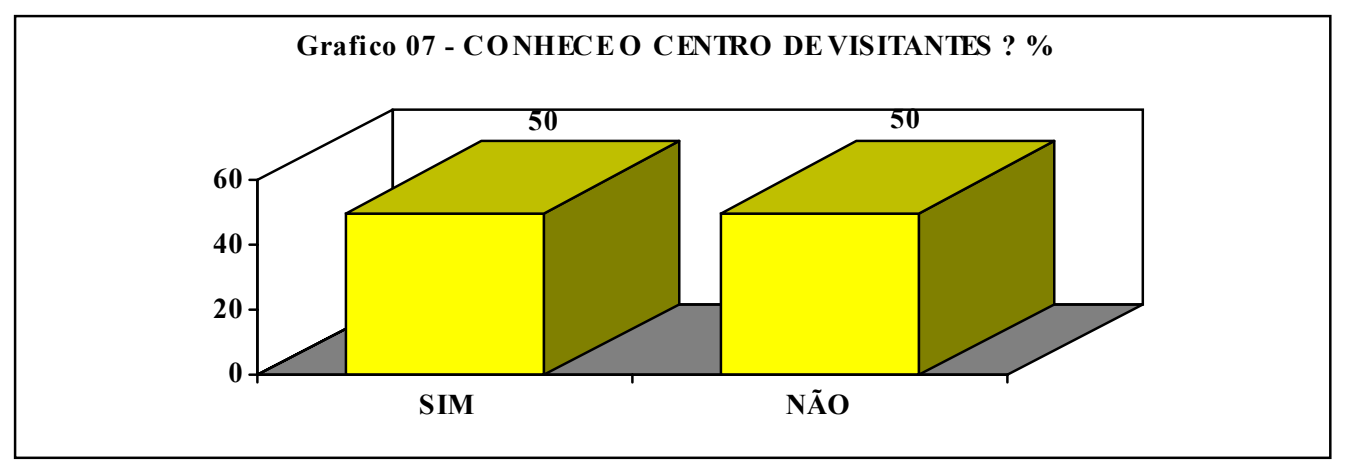

\section{Recebeu alguma informação durante a visita.}

No PNB não existe nenhum tipo de informação sobre o mesmo ou sobre o meio ambiente, apenas no Centro de Visitantes aonde a maioria das pessoas não vão.

Um dos entrevistados relatou que há uns 10 anos atrás, se recebia várias informações sobre o Parque, além de várias palestras que ali eram realizadas, mas que hoje em dia não se vê mais isso. Mesmo assim 16,7\% receberam algum tipo de informação no Parque, como avisos de limpeza. 


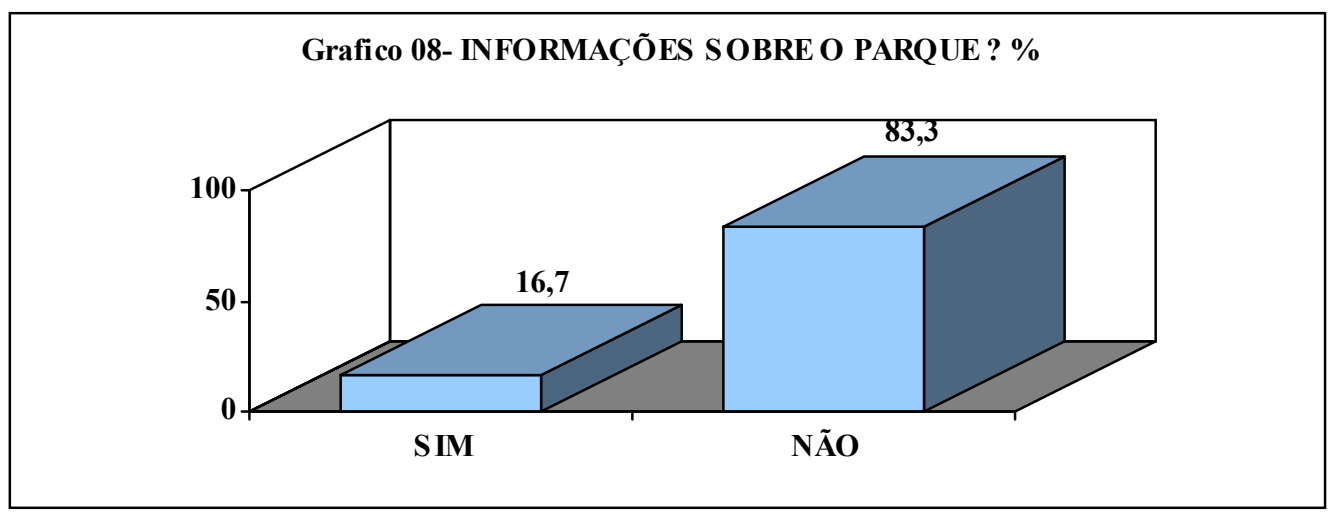

\section{Qualidade dos Serviços e Infra-estrutura.}

$\mathrm{Na}$ avaliação da qualidade de serviços oferecidos ao visitante, bem como da infra-estrutura disponível, o PNB foi avaliado como bom nas duas categorias. A estrutura física, sem dúvida, estimula uma gama maior de tipos de visitantes a procurarem um parque, o que não pode acontecer é essa mesma estrutura atrapalhar o visitante no seu objetivo e no que ele espera da visita.

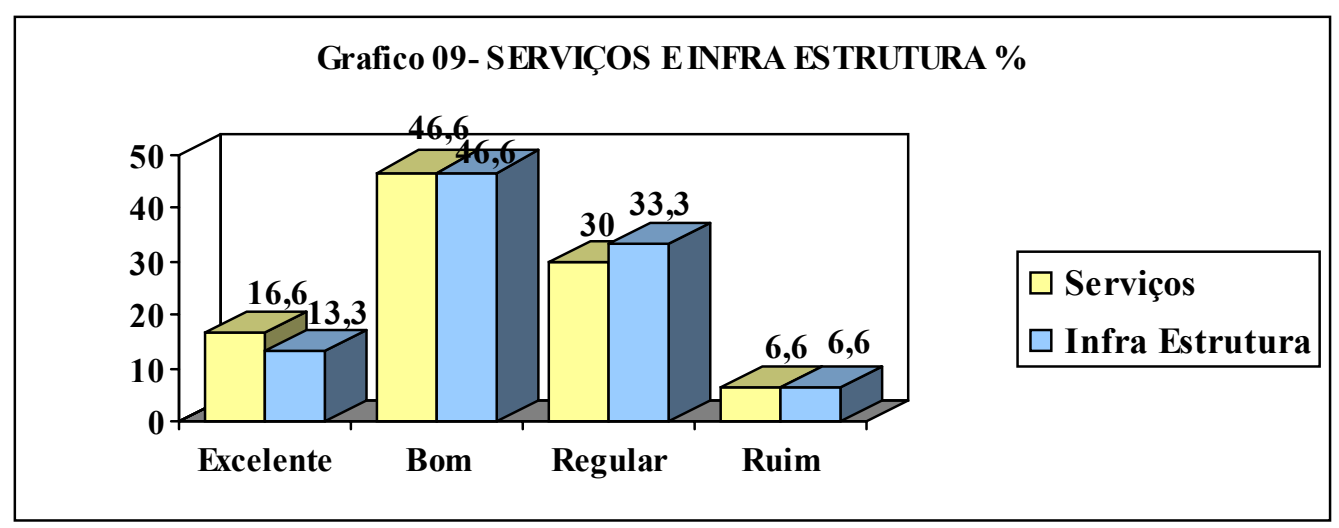

\section{Ingresso}

Uma pequena percentagem dos entrevistados pagam a mensalidade no valor de $R \$ 30,00$ ao mês. A maioria paga a diária no valor de $R \$ 3,00$. Em relação ao valor do ingresso $53,3 \%$ dos entrevistados avaliaram como razoável, conforme o gráfico abaixo:

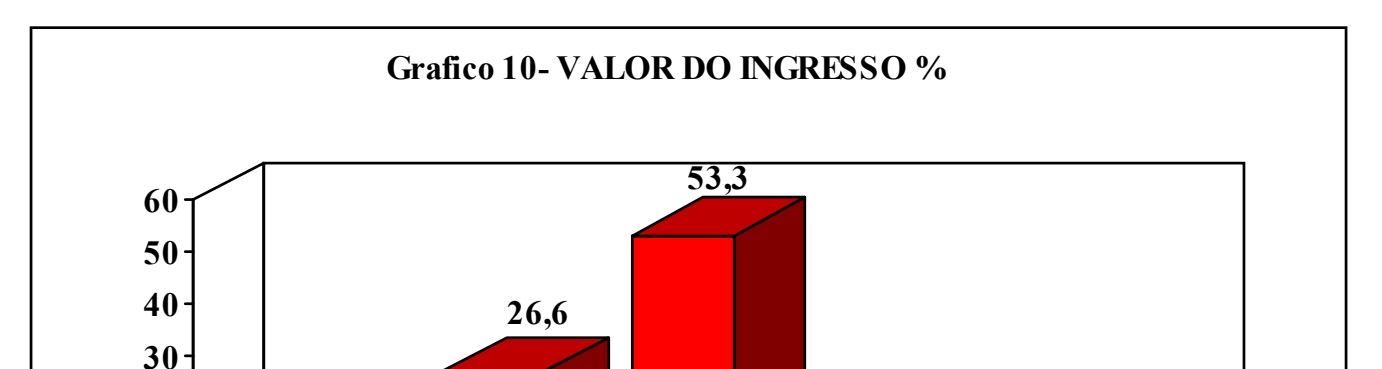


Quanto pagaria pelo ingresso do parque?

A maioria pagaria $R \$ 2,00$ ou $R \$ 3,00$ pelo valor do ingresso, o gráfico ilustra a avaliação do preço do ingresso feita pelos visitantes do PNB:

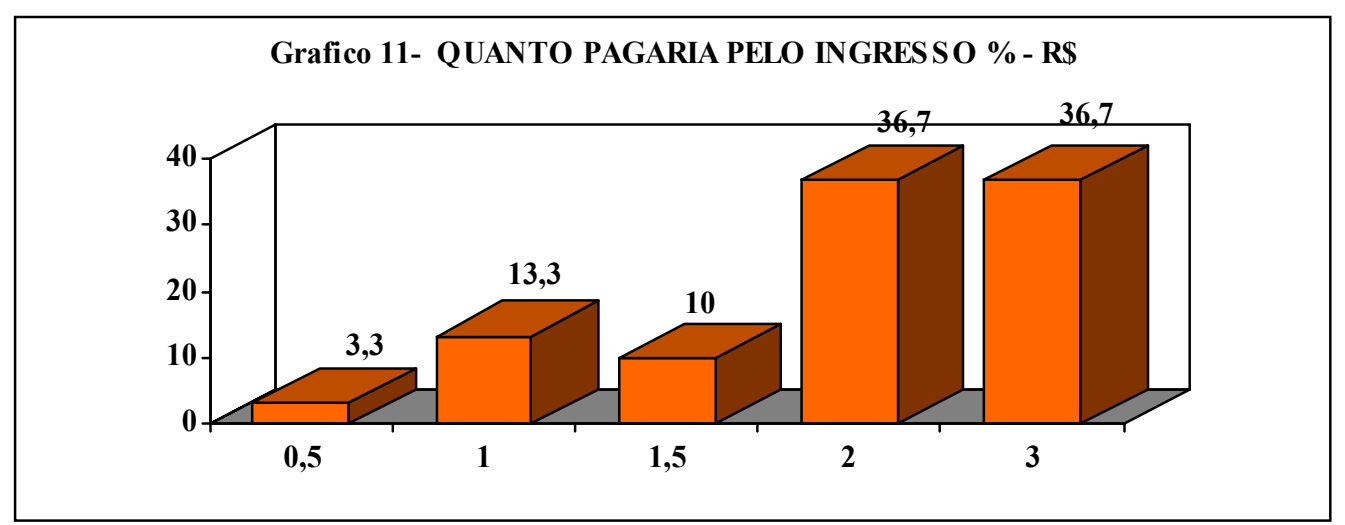

Já ouviu falar em Ecoturismo?

Apenas um dos entrevistados nunca ouviu falar em Ecoturismo.

Grafico 12- OUVIU FALAR EM ECOTURISMO ? \%

96,6

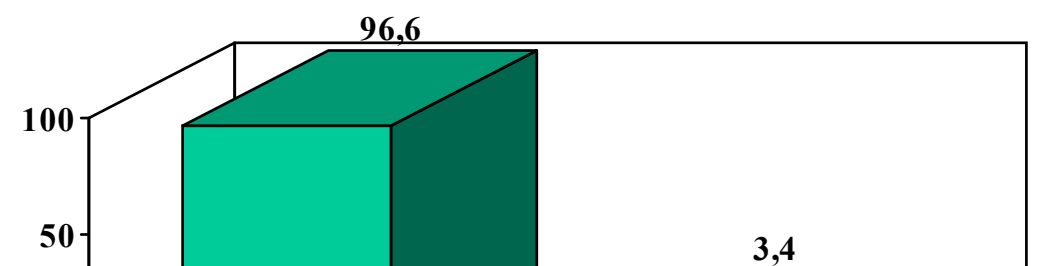


Já praticou o Ecoturismo no PNB?

A maioria nunca praticou o Ecoturismo no PNB, apenas 9 dos entrevistados afirmam já ter praticado.

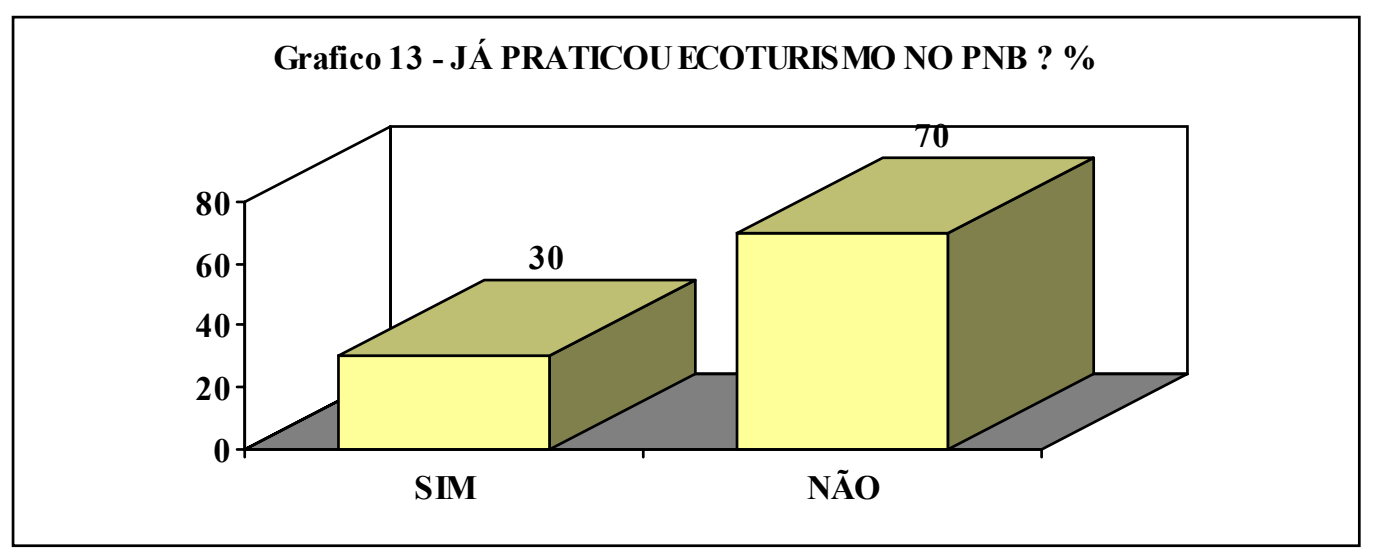

\section{Deseja praticar o Ecoturismo no PNB?}

Todos entrevistados desejam praticar o Ecoturismo no PNB.

Grafico 14 - TEM VONTADE DE PRATICAR ECOTURISMO NO PNB ?

$\%$

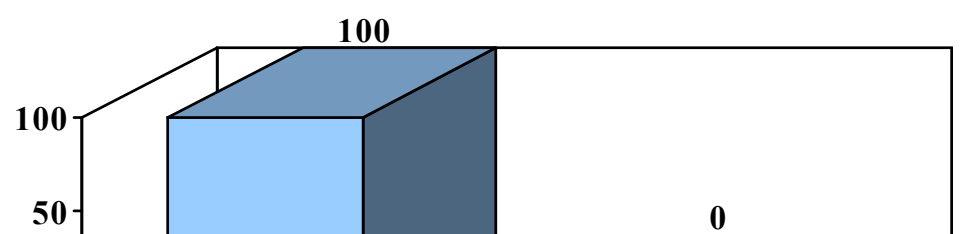


FOLHA DE APROVAÇÃO

\section{DISCUSSÃO DOS RESULTADOS}

Os resultados da análise feita sobre a visitação no PNB, são os seguintes:

- A maioria dos visitantes do PNB moram na Asa Norte, isso ocorre em virtude do Parque estar localizado perto da Asa Norte, favorecendo os moradores desse bairro de classe media de Brasília. 


\section{FOLHA DE APROVAÇÃO}

- As pessoas mais adultas entre 25 e 34 anos são as que mais freqüentam o Parque. Os mais jovens quase não freqüentam, por falta de estímulo e informação.

- A maioria tem nível superior e a renda varia entre $R \$ 300,00$ e $R \$$ $1.000,00$ mensais, o indica que o Parque recebe tipos alternativos de visitantes, independente da classe social.

- As atividades mais praticadas são lazer, corridas e natação. O ideal, é que se ofereçam através do Ecoturismo opções variadas de atividades para os visitantes, evitando assim, a aglomeração em determinados pontos do Parque.

- No PNB não existe nenhum tipo de informação para o visitante, nem na entrada nem na saída, nem nas áreas das piscinas onde há uma grande aglomeração de pessoas. Um Parque Nacional necessita de informação, principalmente na entrada, onde o visitante terá conhecimento do que ver e desfrutar do Parque Nacional.

- O visitante que leva a família para o PNB procura uma melhor infraestrutura de apoio. A sensação de estar num local mais ecológico, em contato com a natureza, mas que possui uma infra-estrutura de apoio, é o que agrada as pessoas em suas visitas a um Parque Nacional.

- O PNB possui uma boa infra-estrutura, mas precisa harmonizá-la com o meio ambiente. Os serviços prestados devem ser de mais qualidade, os banheiros e as lanchonetes devem estar sempre limpos.

- Os visitantes do PNB afirmam que sentem falta e gostariam de receber informações sobre o Parque, o meio ambiente, e sustentabilidade, e estariam dispostos a participar de palestras ou mostra audiovisual.

- O preço do ingresso é considerado razoável pela maioria, o Parque pode estipular dias da semana onde o ingresso é mais barato.

- $30 \%$ dos entrevistados afirmaram já ter praticado de alguma forma o Ecoturismo no PNB, como as caminhadas nas trilhas ecológicas.

- Todos entrevistados têm vontade de praticar o Ecoturismo no PNB, no entanto, se vê que a comunidade tem grande interesse nos benefícios que o Ecoturismo pode trazer para o PNB. 
FOLHA DE APROVAÇÃO

\section{CONCLUSÃO}

O Ecoturismo depende da existência de áreas de elevado valor ecológico e cultural, da maneira como estas áreas são geridas, da existência 


\section{FOLHA DE APROVAÇÃO}

de infra-estruturas adequadas e da disponibilidade de recursos humanos capacitados.

Através de um modelo de gestão alternativo no PNB, com a participação de todos os setores interessados, principalmente a comunidade, a mais interessada, podemos desenvolver qualidade de vida e benefícios ao Parque através do Ecoturismo.

Se o Parque é um bem público, a comunidade deve participar de sua gestão. As pessoas só protegem aquilo que elas conhecem, ou sabem da importância. A sociedade de Brasília tem que conhecer melhor o PNB, as suas riquezas, quais os benefícios que ele oferece, para poder melhor protegê-lo.

A indefinição política infelizmente, não permite que se estabeleçam estratégias e prioridades que alavanquem o Ecoturismo no PNB. É preciso garantir que toda essa beleza natural, grande diversidade biológica e riqueza histórico-cultural, que se destacam no PNB contribuam para uma melhor qualidade de vida dos seus cidadãos e os façam pessoas satisfeitas e favoráveis à recepção de turistas, com profissionalismo, competência, qualidade, cortesia e alegria.

A atividade ecoturística no PNB deverá ser praticada com organização, objetivos e estratégias bem definidas. Tendo uma preocupação verdadeira com a infra-estrutura, de forma a se tornar um instrumento do desenvolvimento local sustentado, garantindo a melhoria da qualidade de vida, oferta de novos empregos e geração de renda para manutenção do Parque e para a sociedade local.

\section{ANEXOS}

\section{MAPAS}




\title{
Parque Nacional de Brasília
}

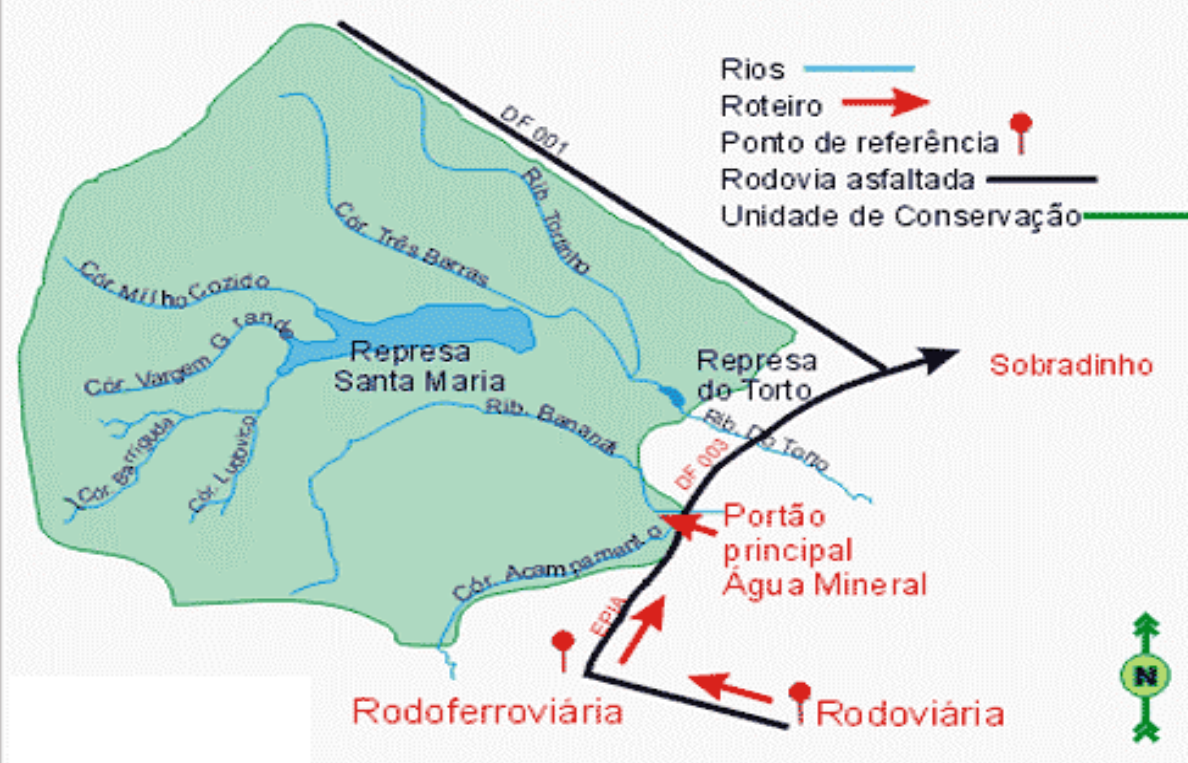

Fonte: www.viaecológica.com.br

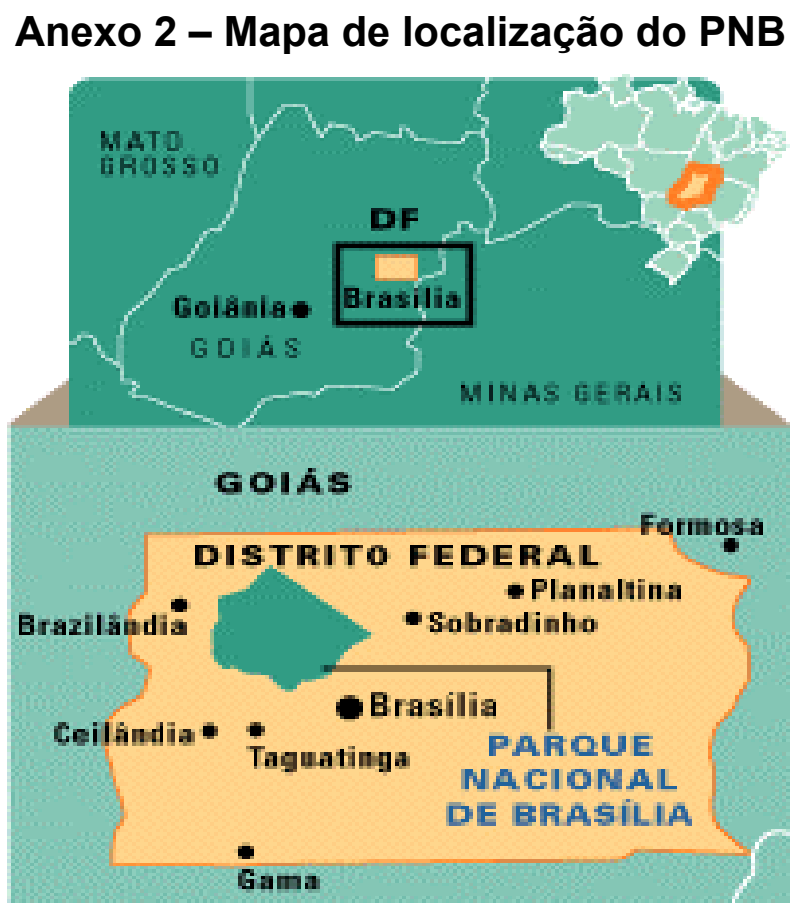

Fonte: www.ancoradouro.com.br

\section{FOTOS DO PNB}

\author{
Anexo 3 - Guarita
}


FOLHA DE APROVAÇÃO

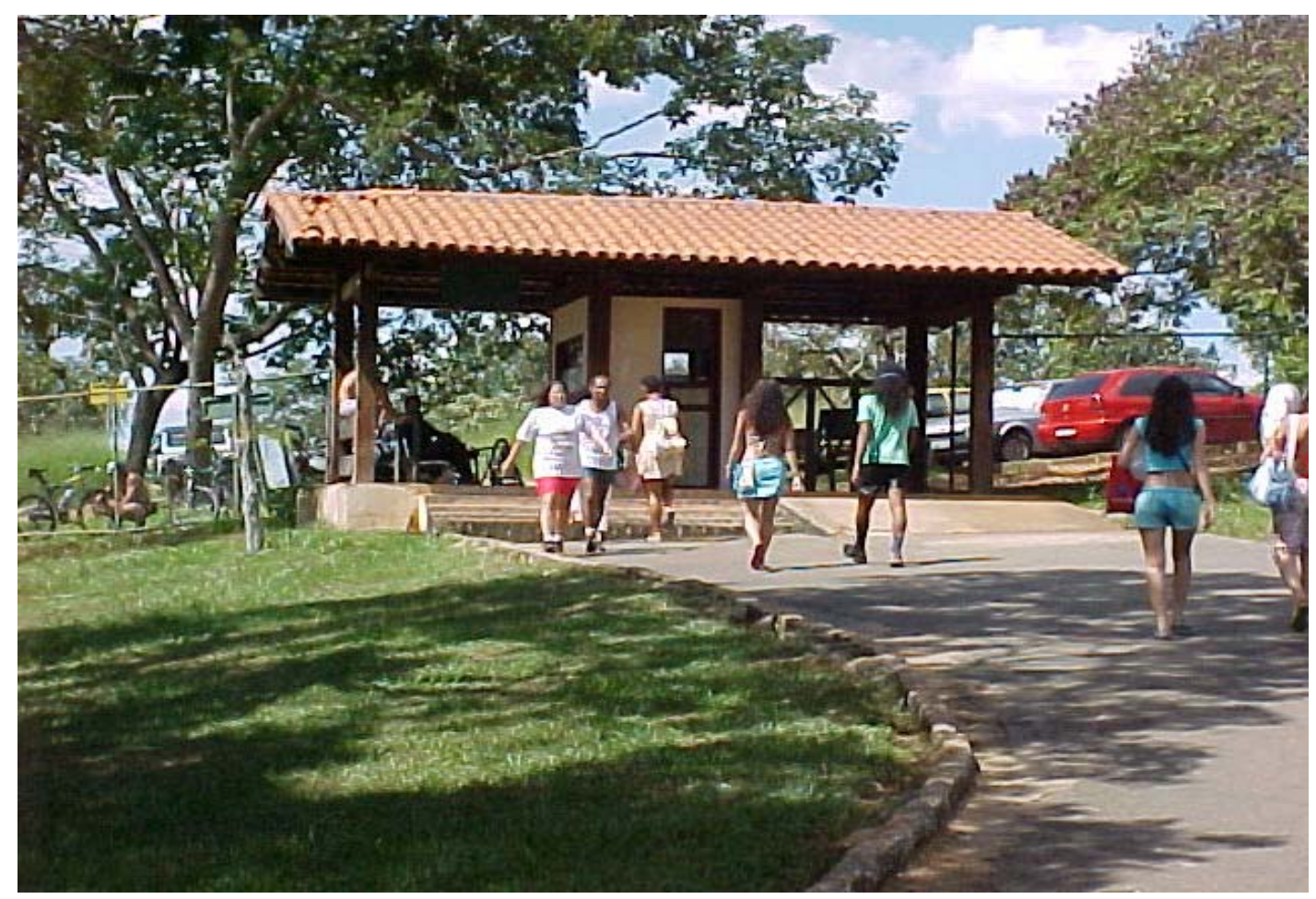

\section{Anexo 4 - Piscina}

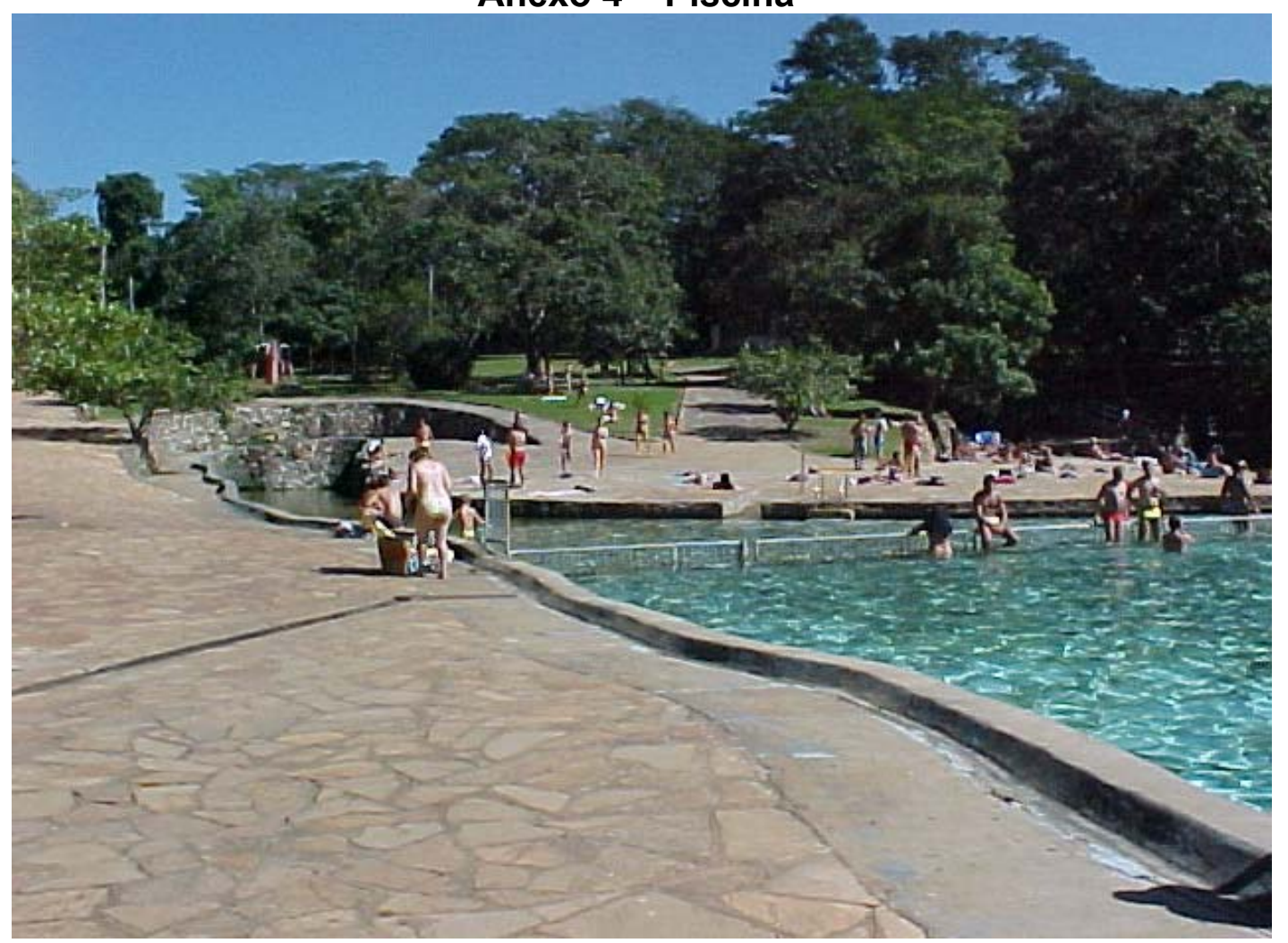




\section{FOLHA DE APROVAÇÃO}

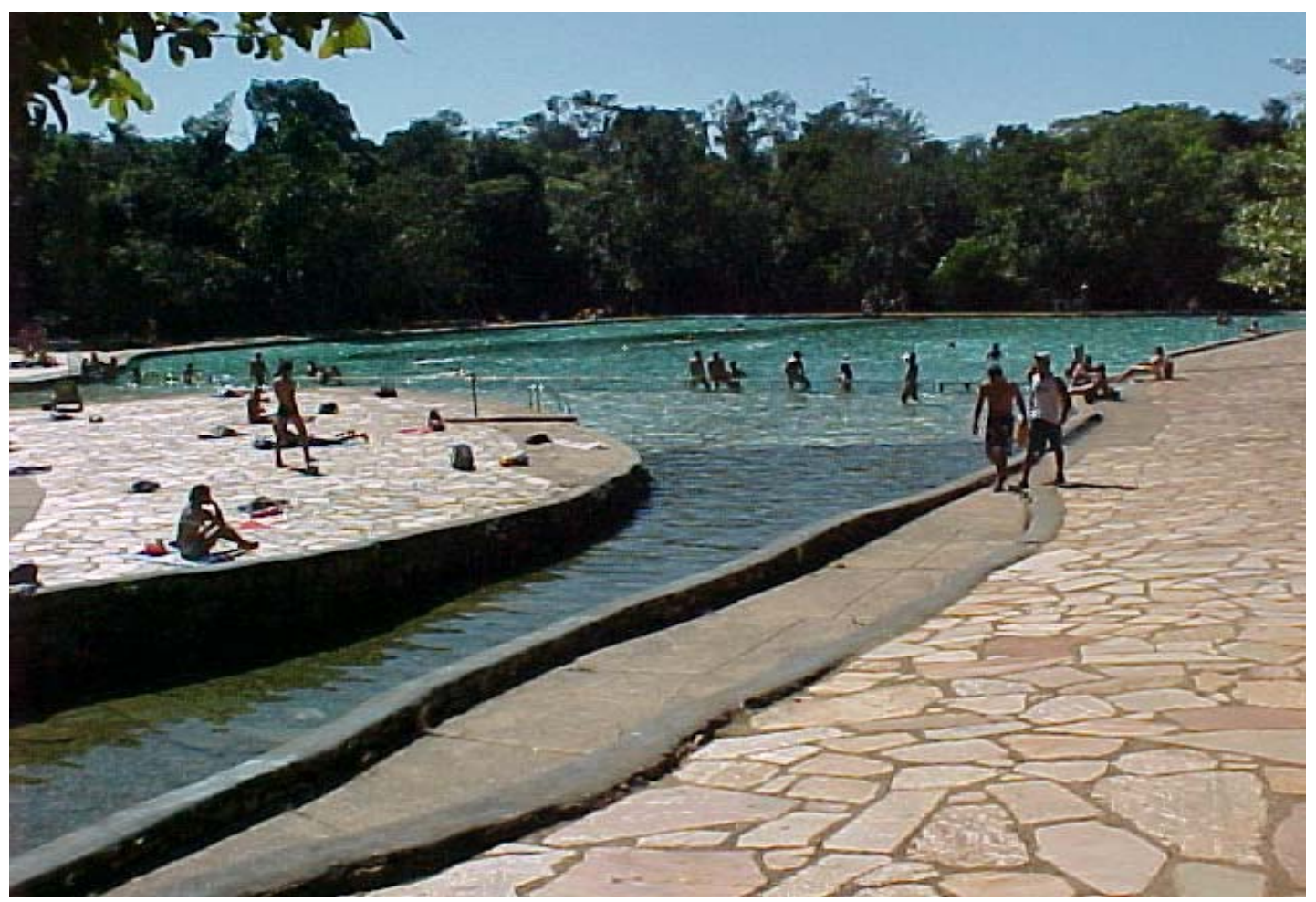

\section{Anexo 6 - Placa de informação}

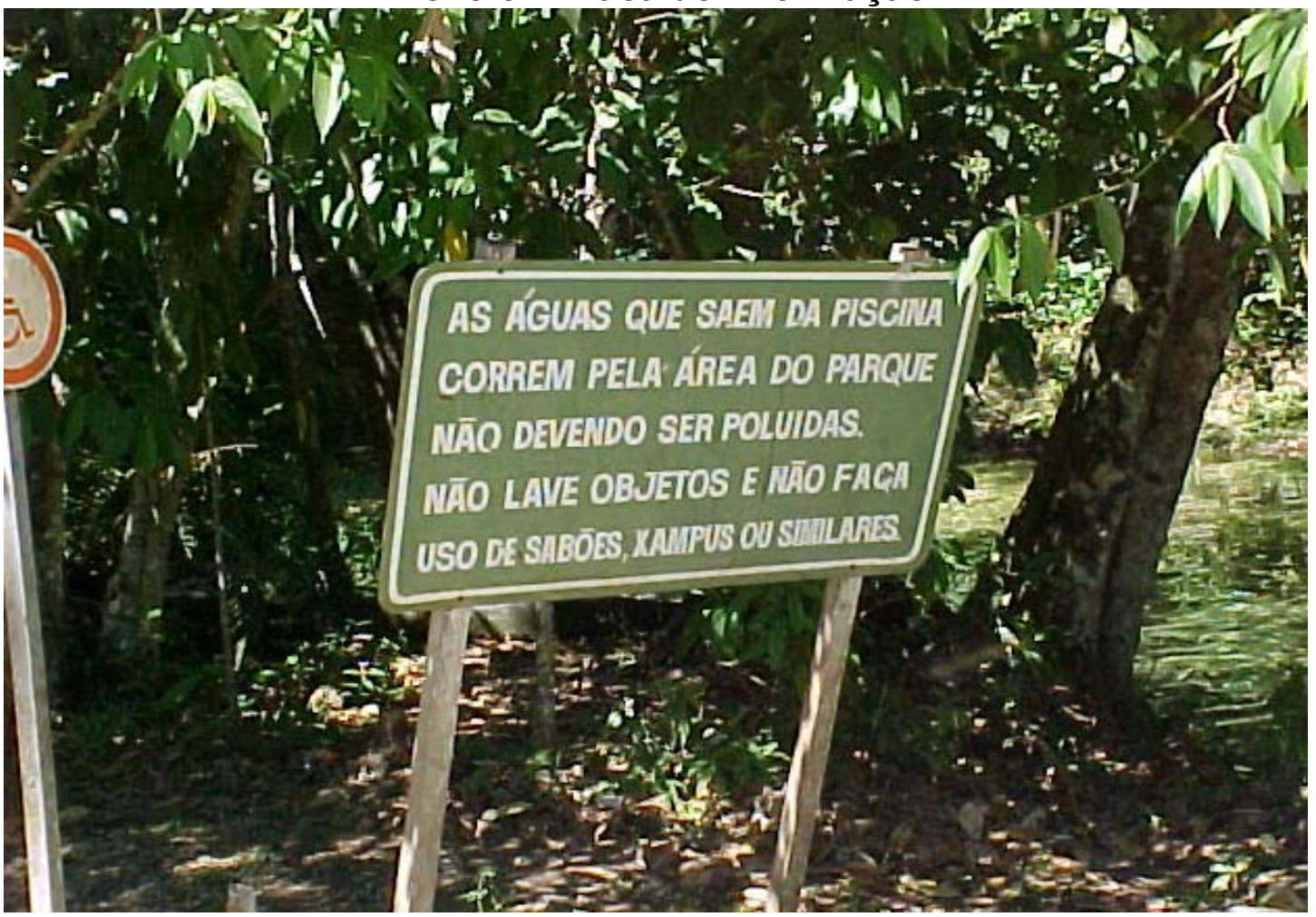




\section{FOLHA DE APROVAÇÃO}

\section{Anexo 7 - Queda d'água da Piscina}

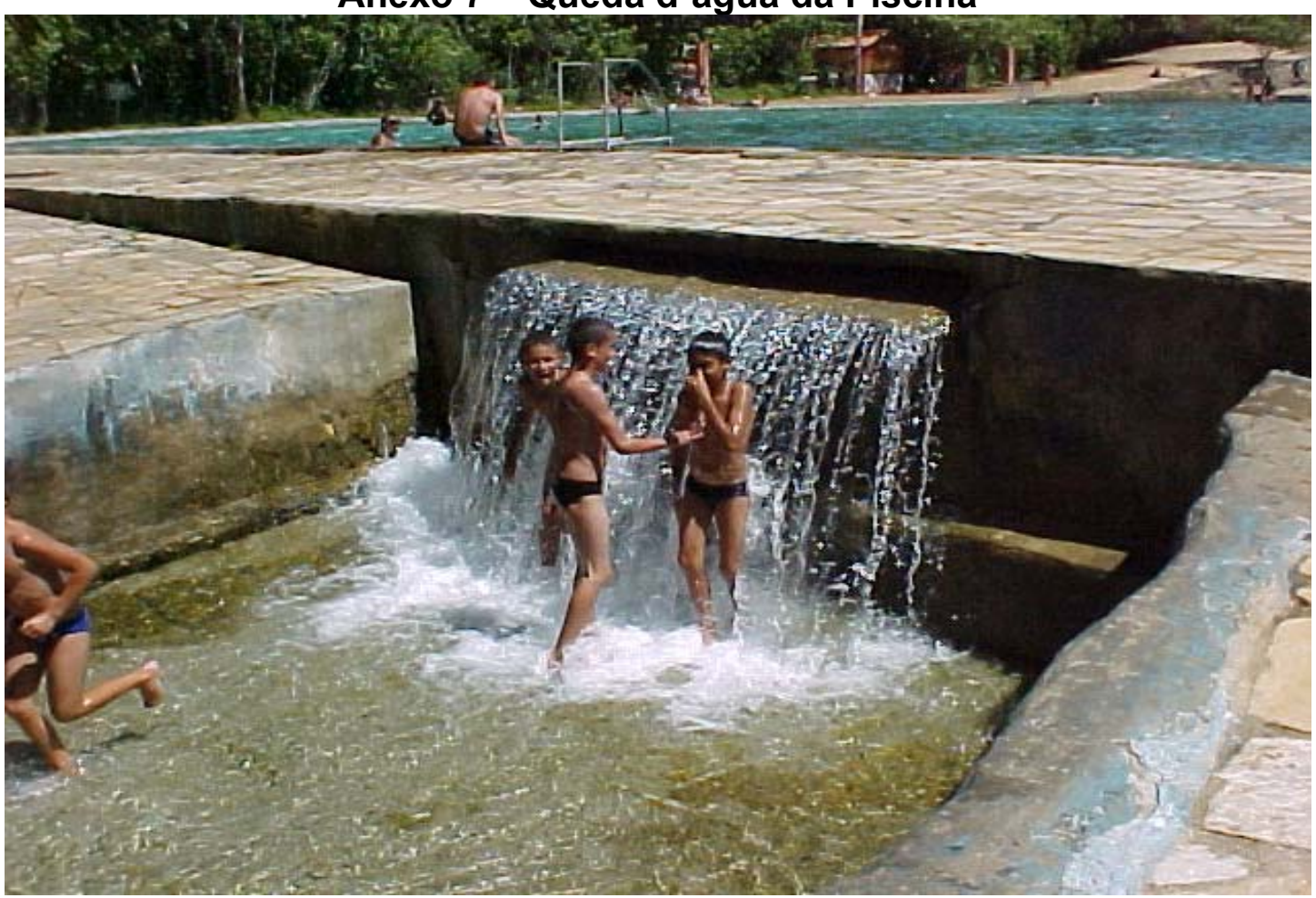

\section{Anexo 8 - Banheiros}

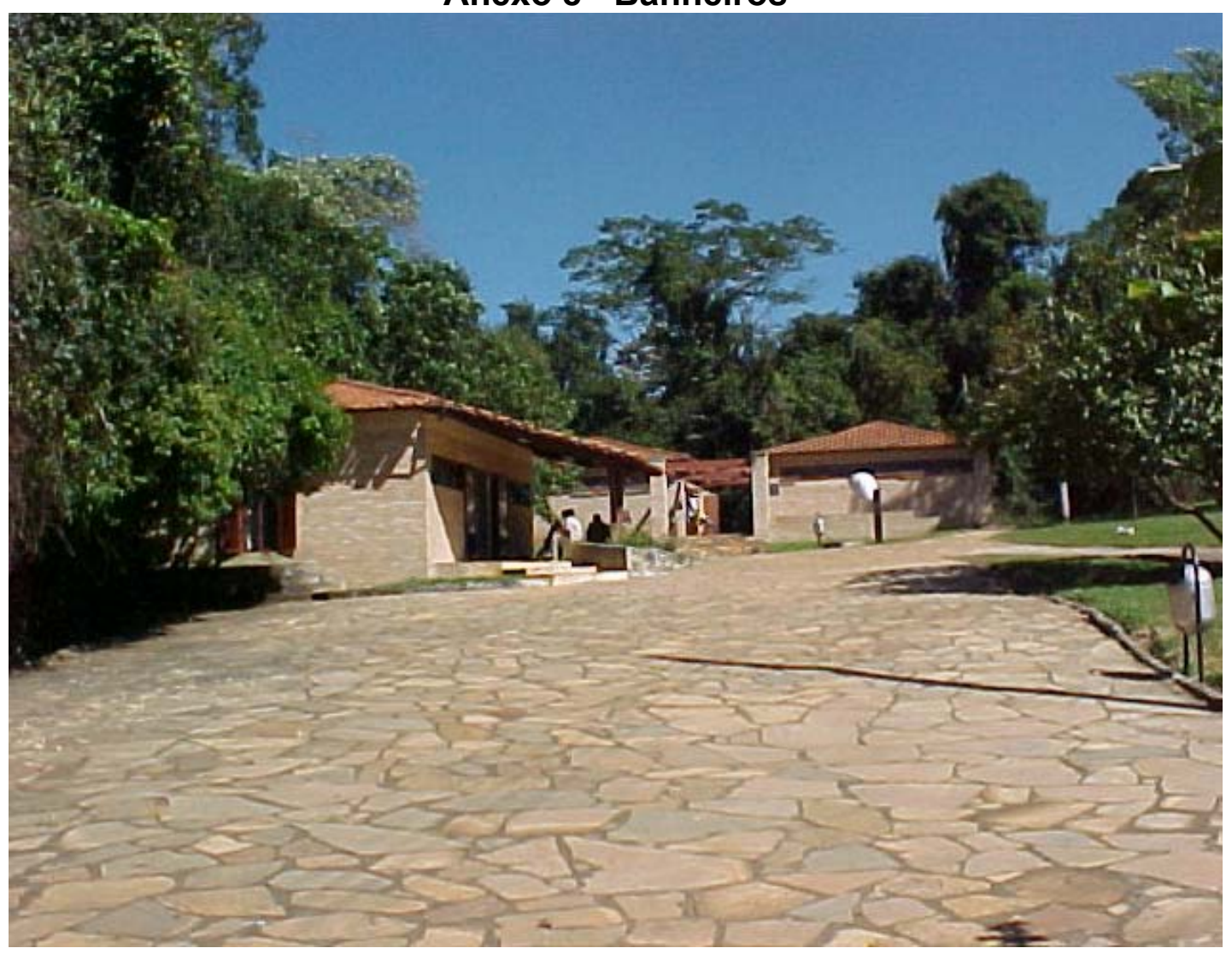




\section{FOLHA DE APROVAÇÃO}

\section{Anexo 9 - Barras de musculação}

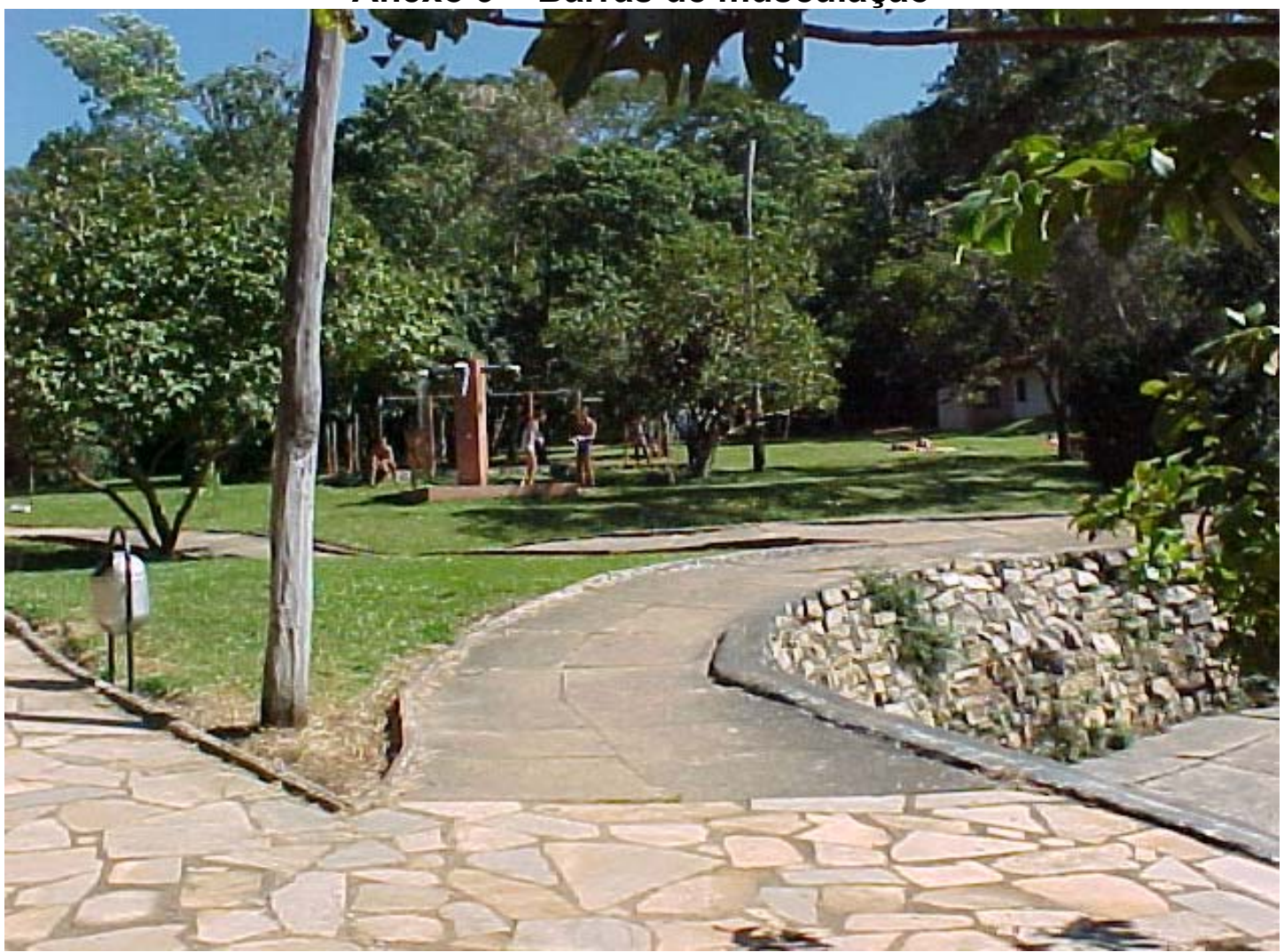

\section{Anexo 10 - Lanchonete}

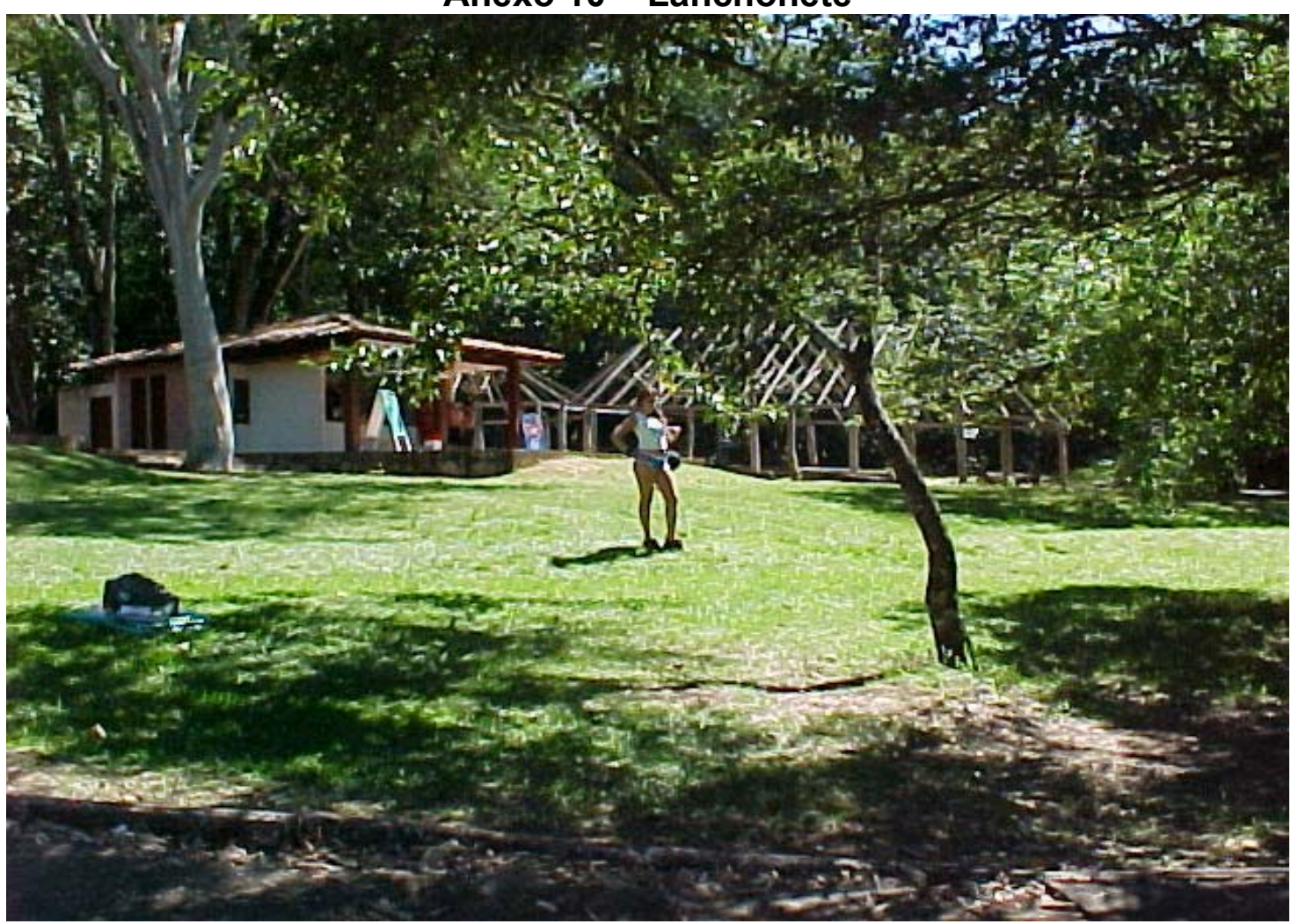




\section{FOLHA DE APROVAÇÃO}

\section{Anexo 11 - Acesso para Trilhas e Centro de Visitantes}

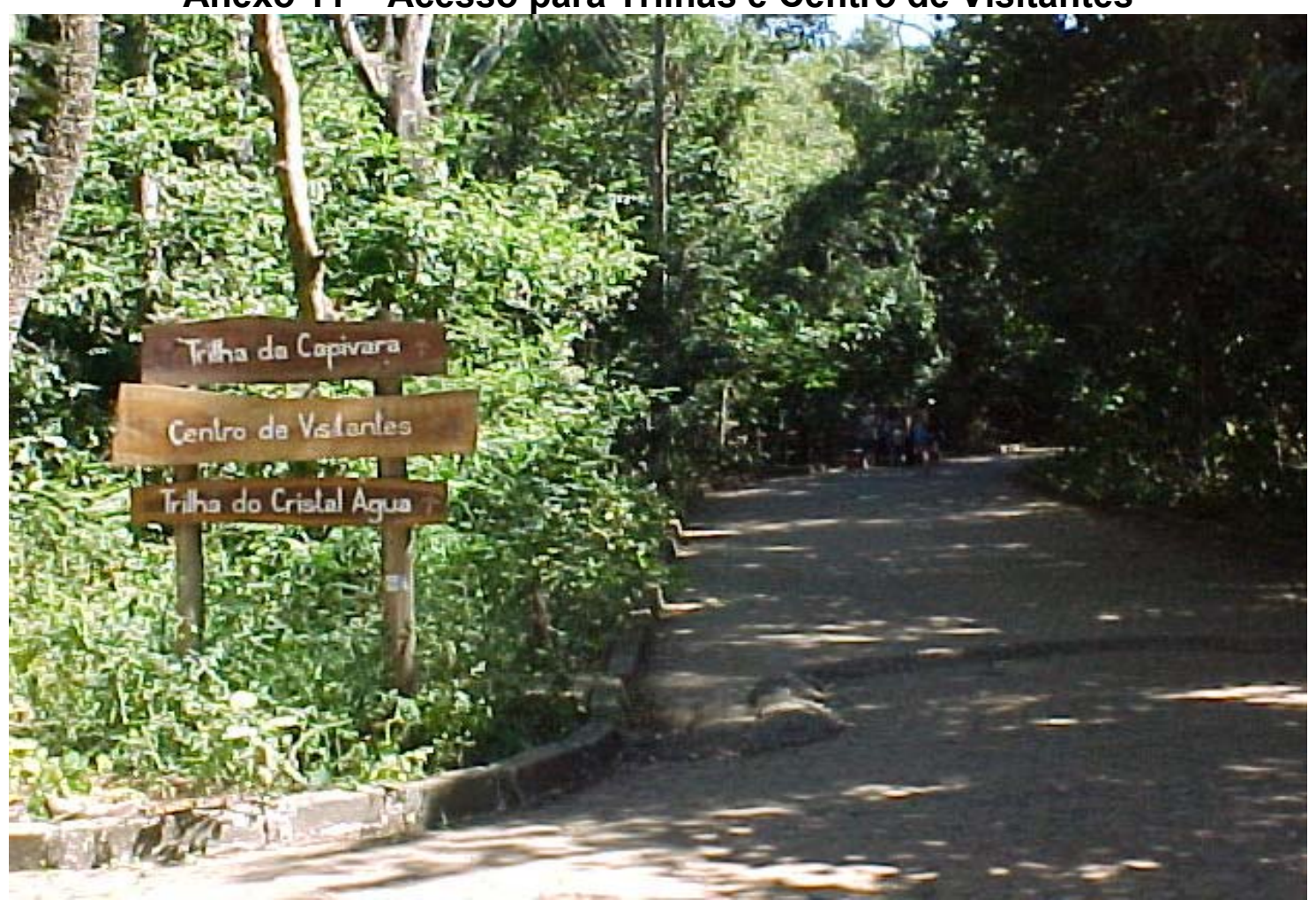

\section{Anexo 12 - Trilha da Capivara}

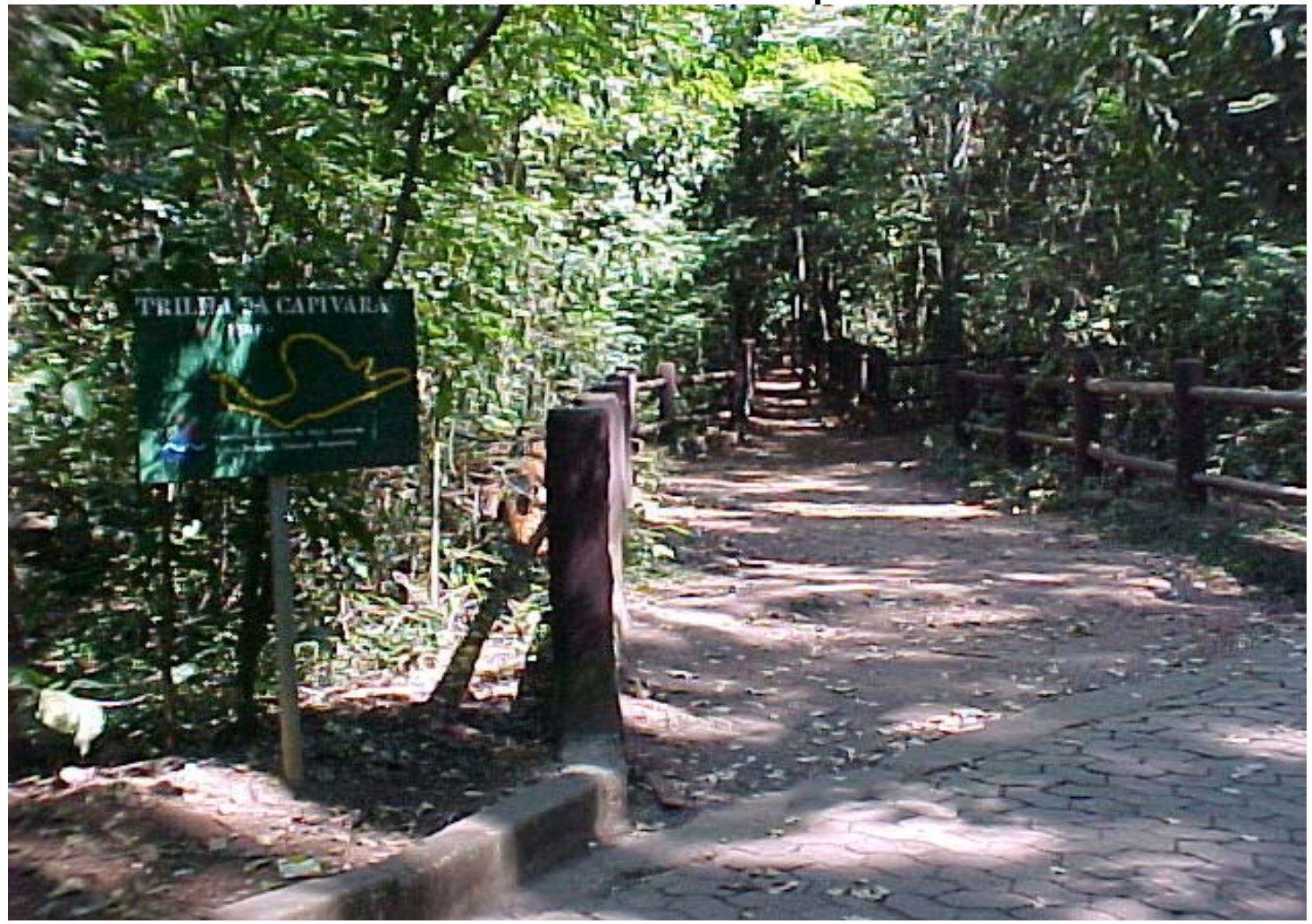




\section{FOLHA DE APROVAÇÃO}

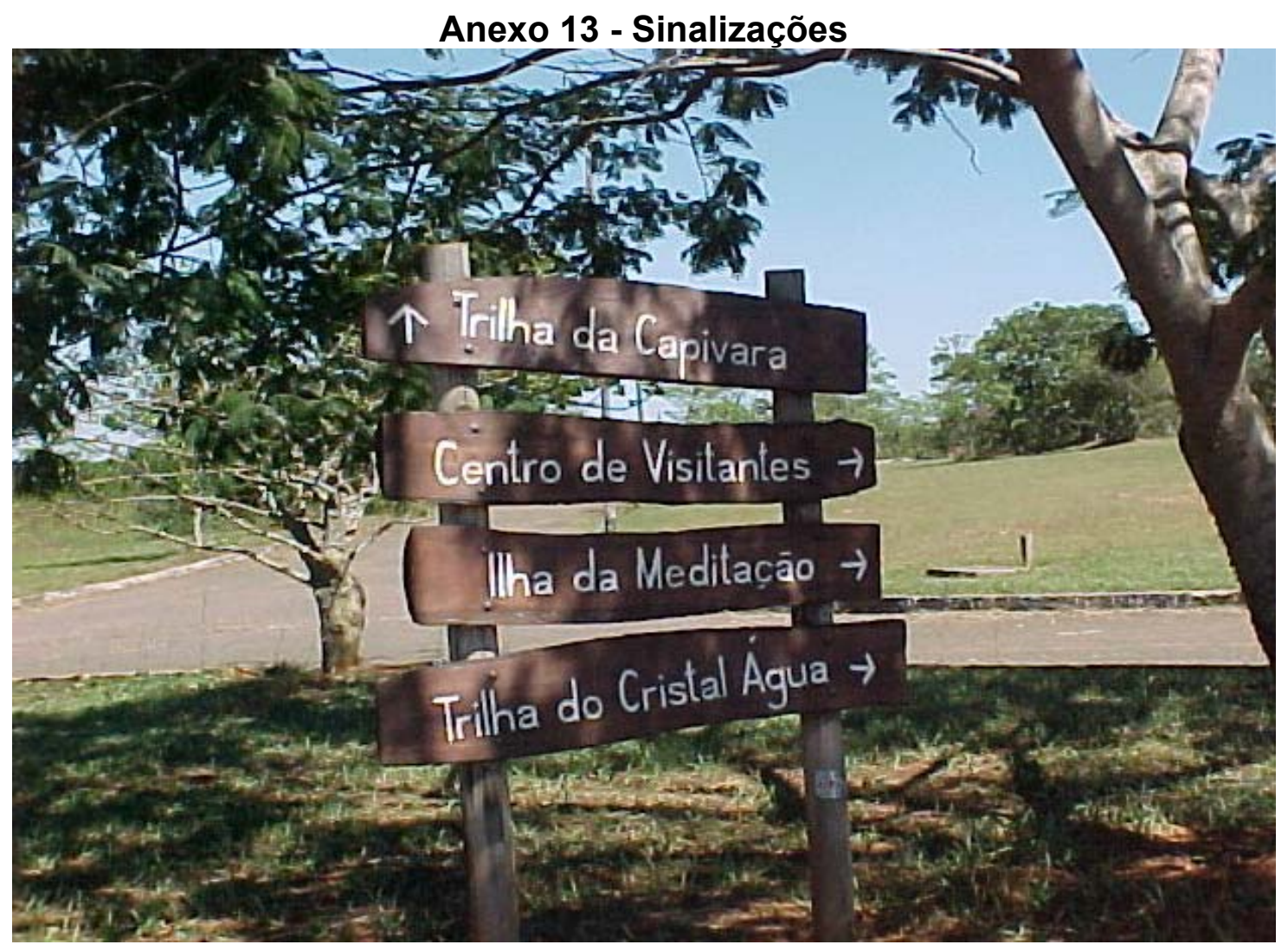

Anexo 14 - Acesso para o Centro de Visitantes 


\section{FOLHA DE APROVAÇÃO}

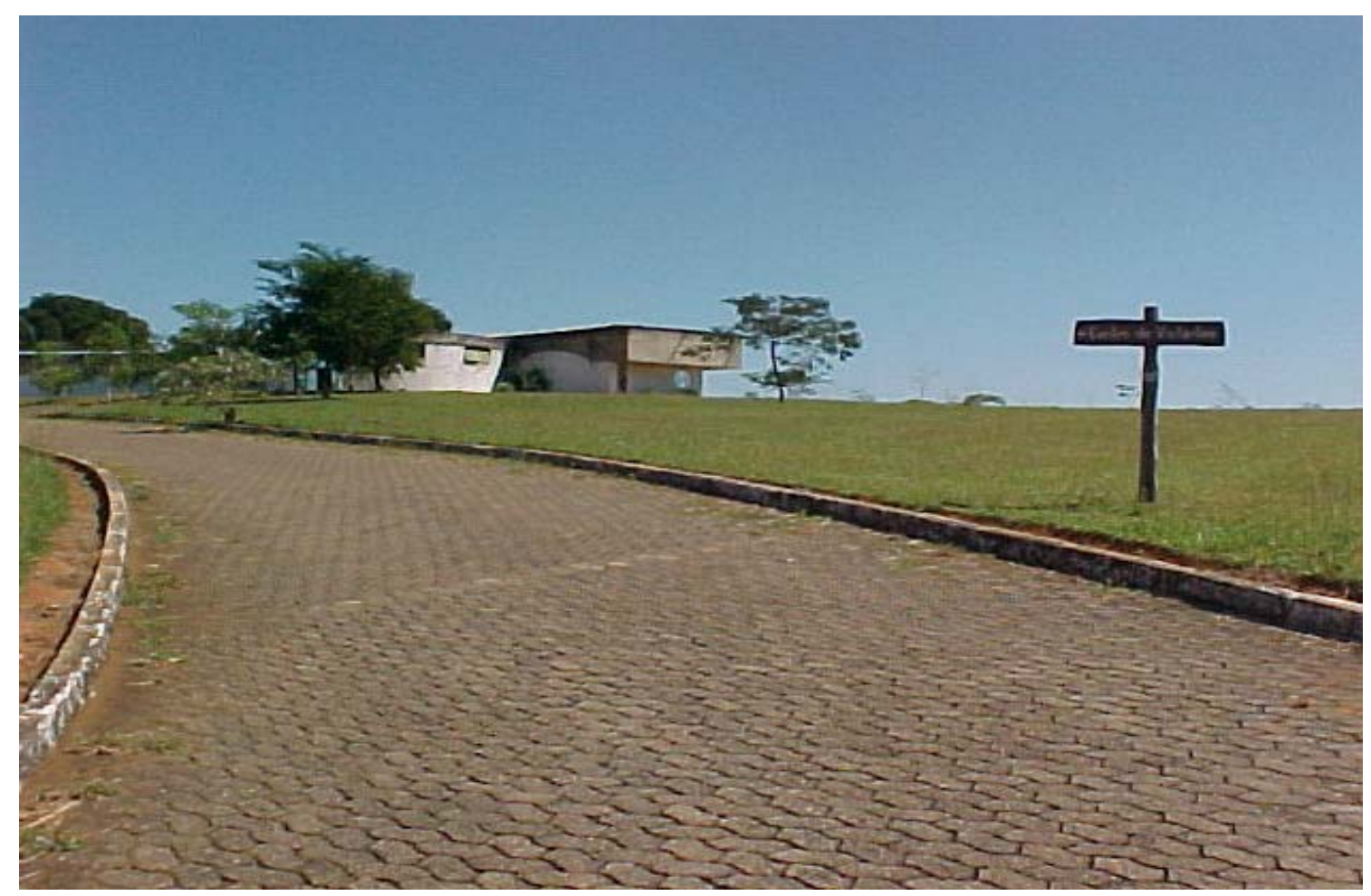

FOTOS DO CENTRO DE VISITANTES DO PNB

Anexo 15 - Estrutura do Centro de Visitantes 
FOLHA DE APROVAÇÃO

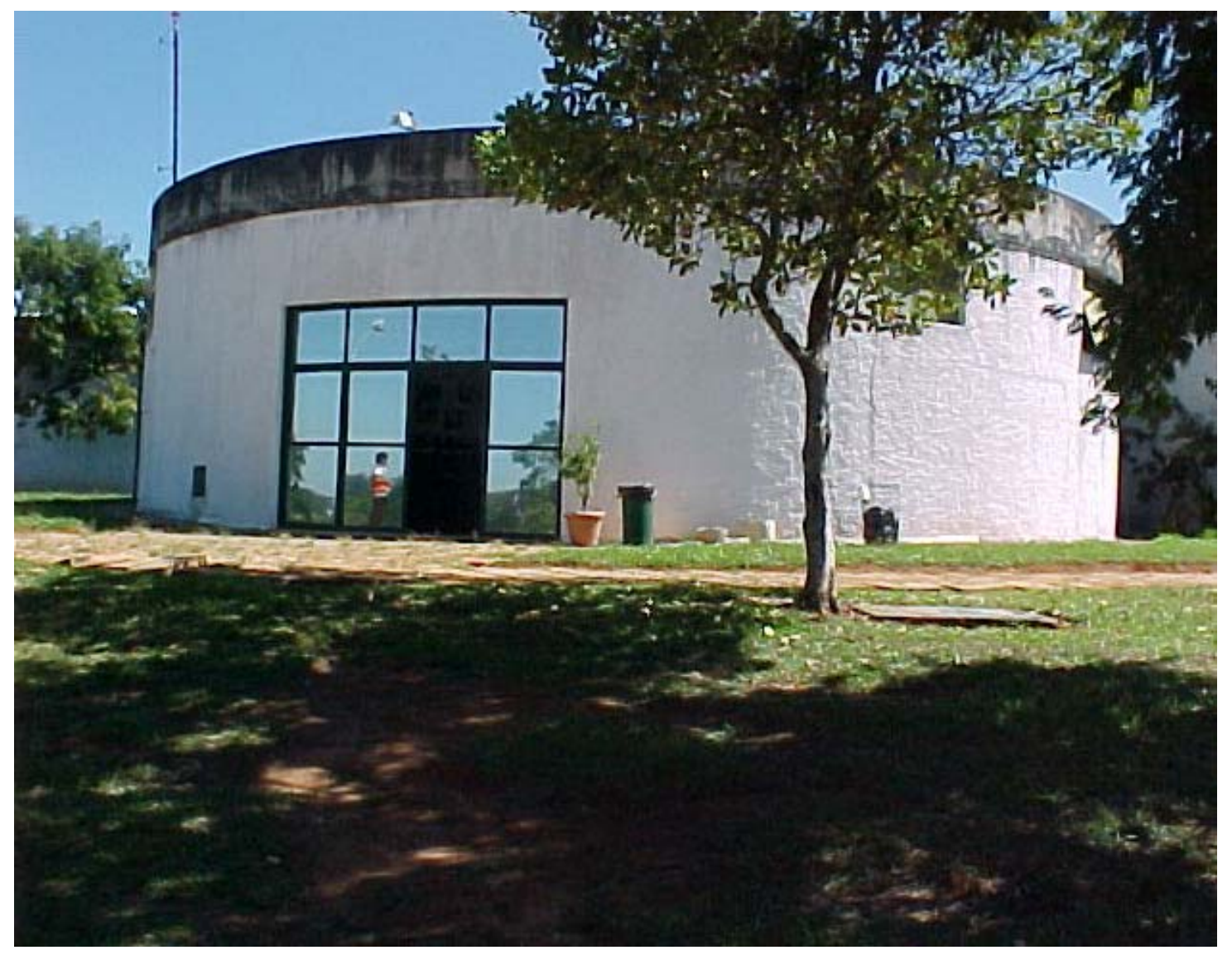

Anexo 16 - Entrada Centro de visitantes 
FOLHA DE APROVAÇÃO

$$
\begin{gathered}
\text { PARQUE IACIONAL } \\
\text { BRAE ILILA }
\end{gathered}
$$

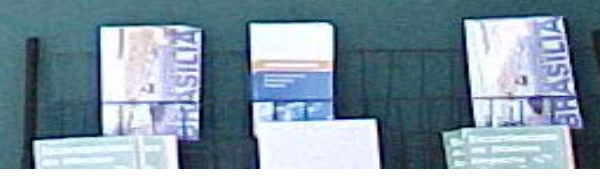

Anexo 17 - Foto aérea PNB 
FOLHA DE APROVAÇÃO

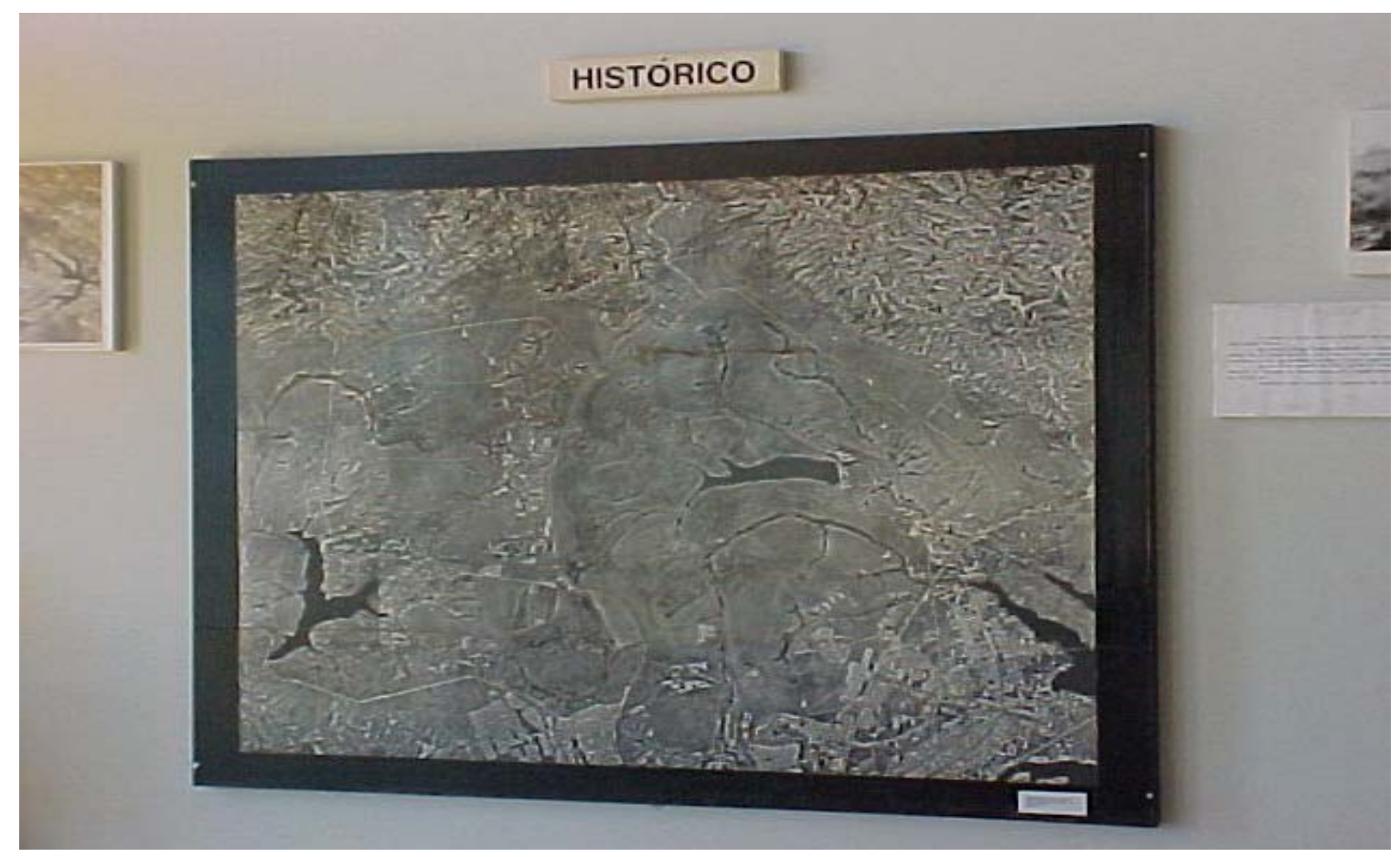




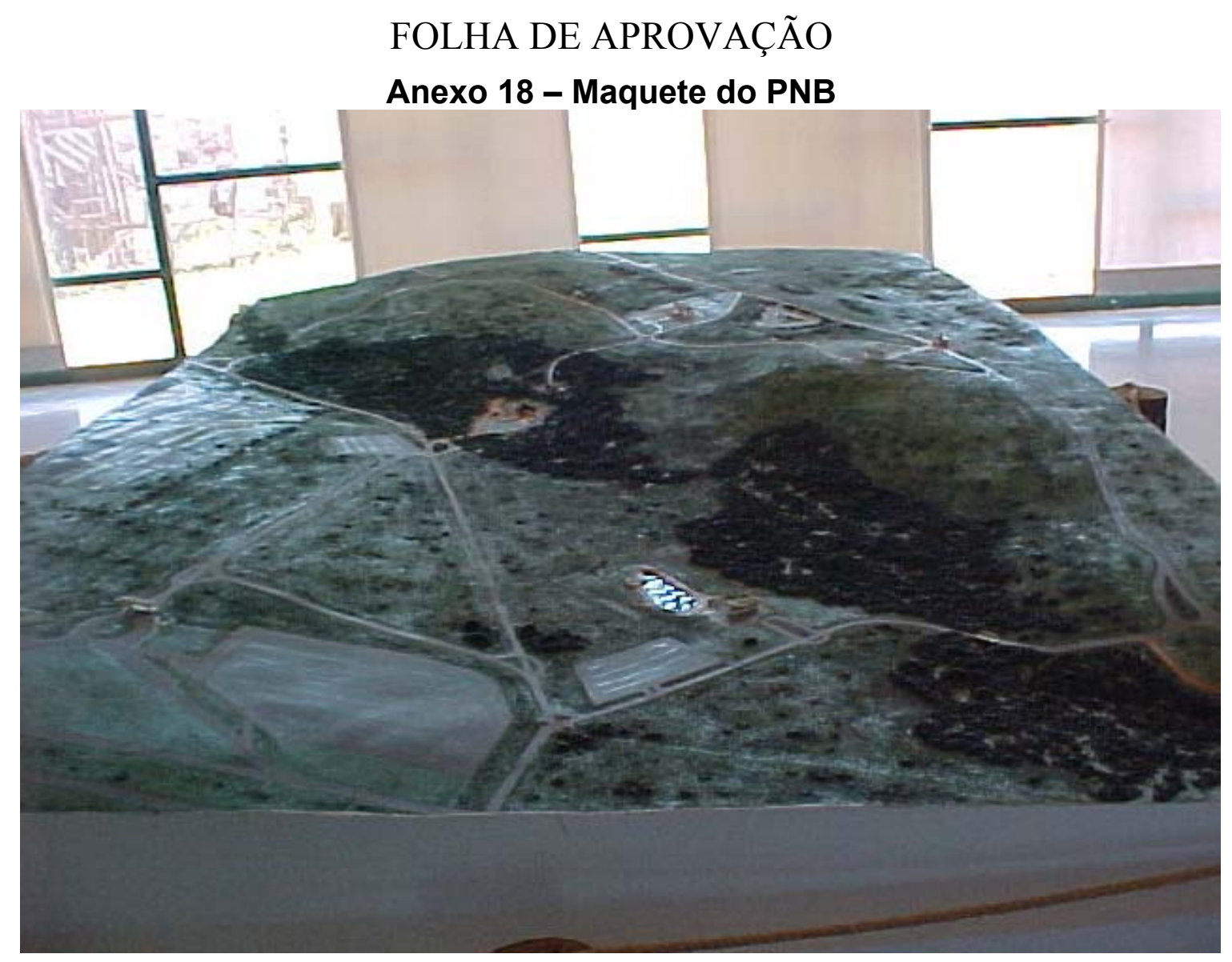

Anexo 19 - Informações sobre a vegetação do PNB

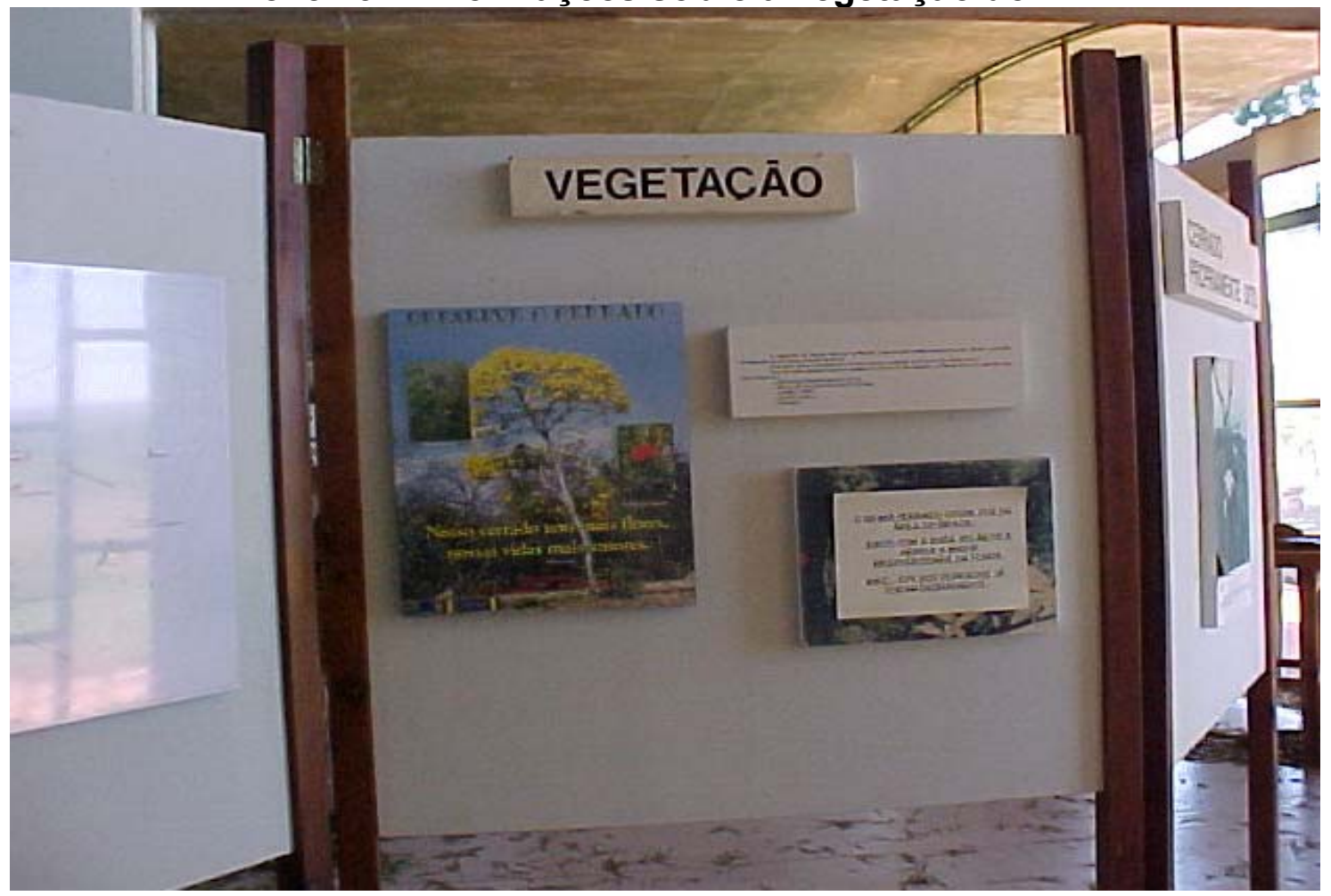




\section{FOLHA DE APROVAÇÃO}

\section{Anexo 20 - Exposição da fauna e vegetação}
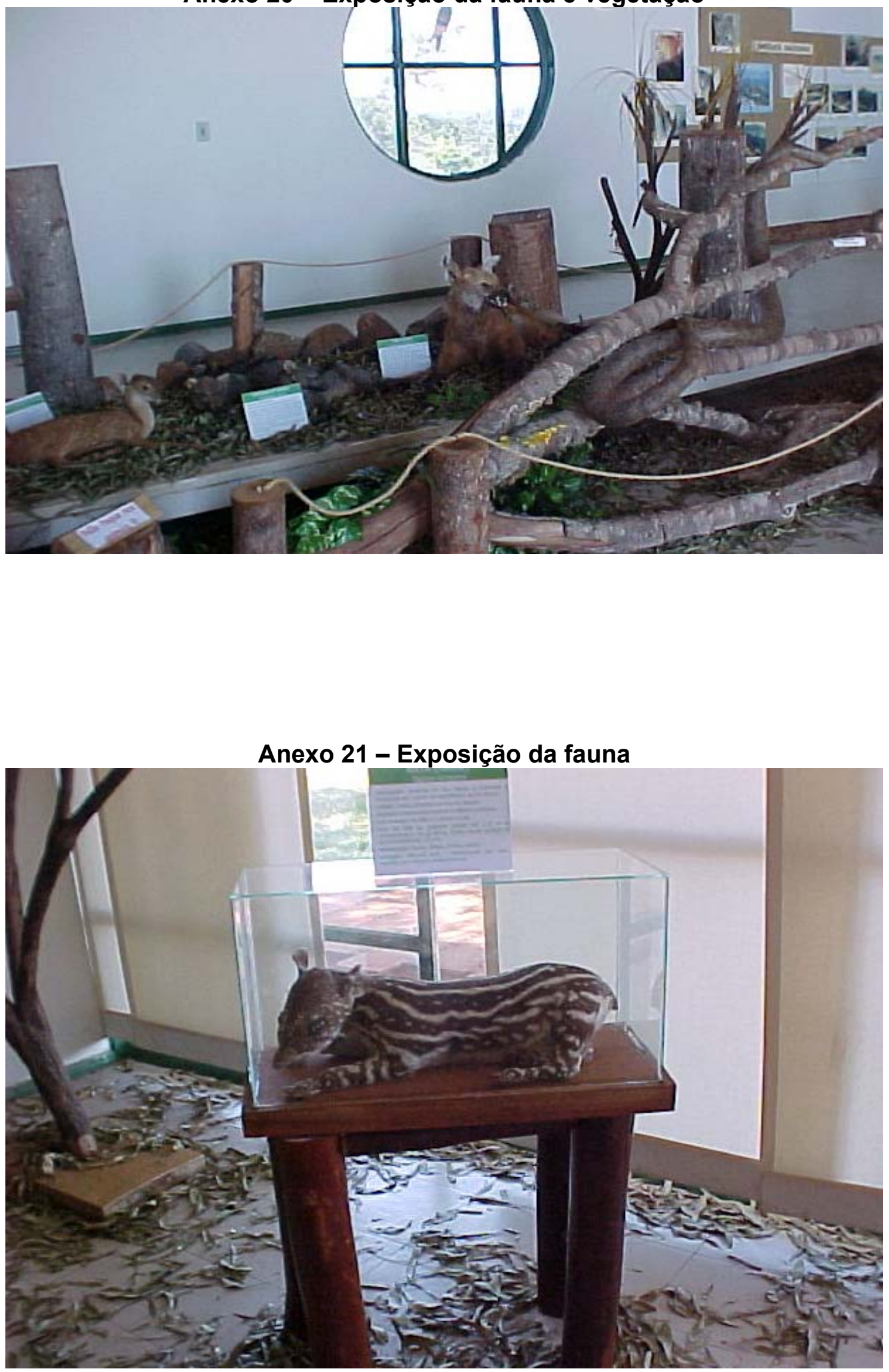


\section{FOLHA DE APROVAÇÃO}

Anexo 22 - Informações e exposição sobre prevenção de fogo

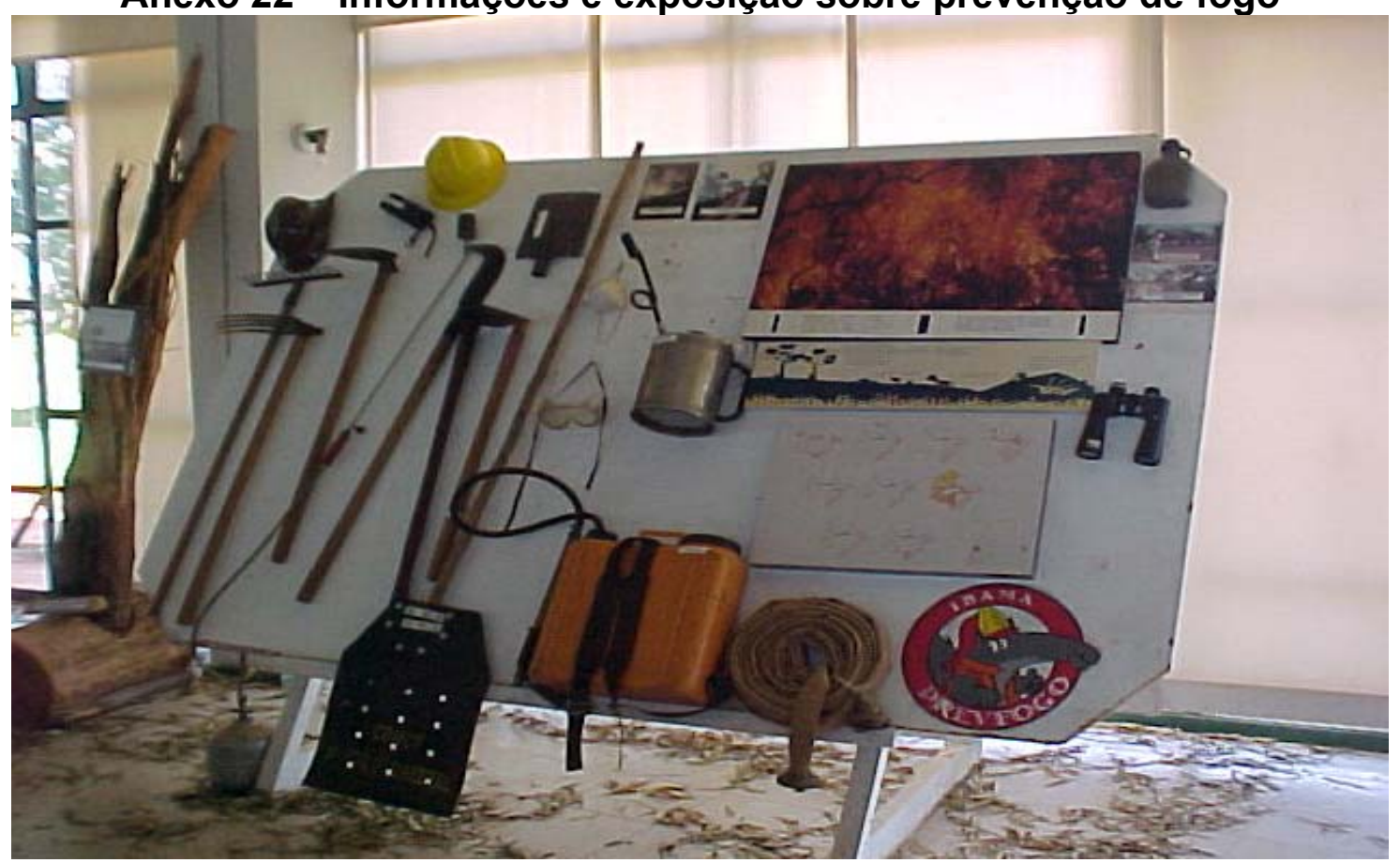

Anexo 23 - Auditório

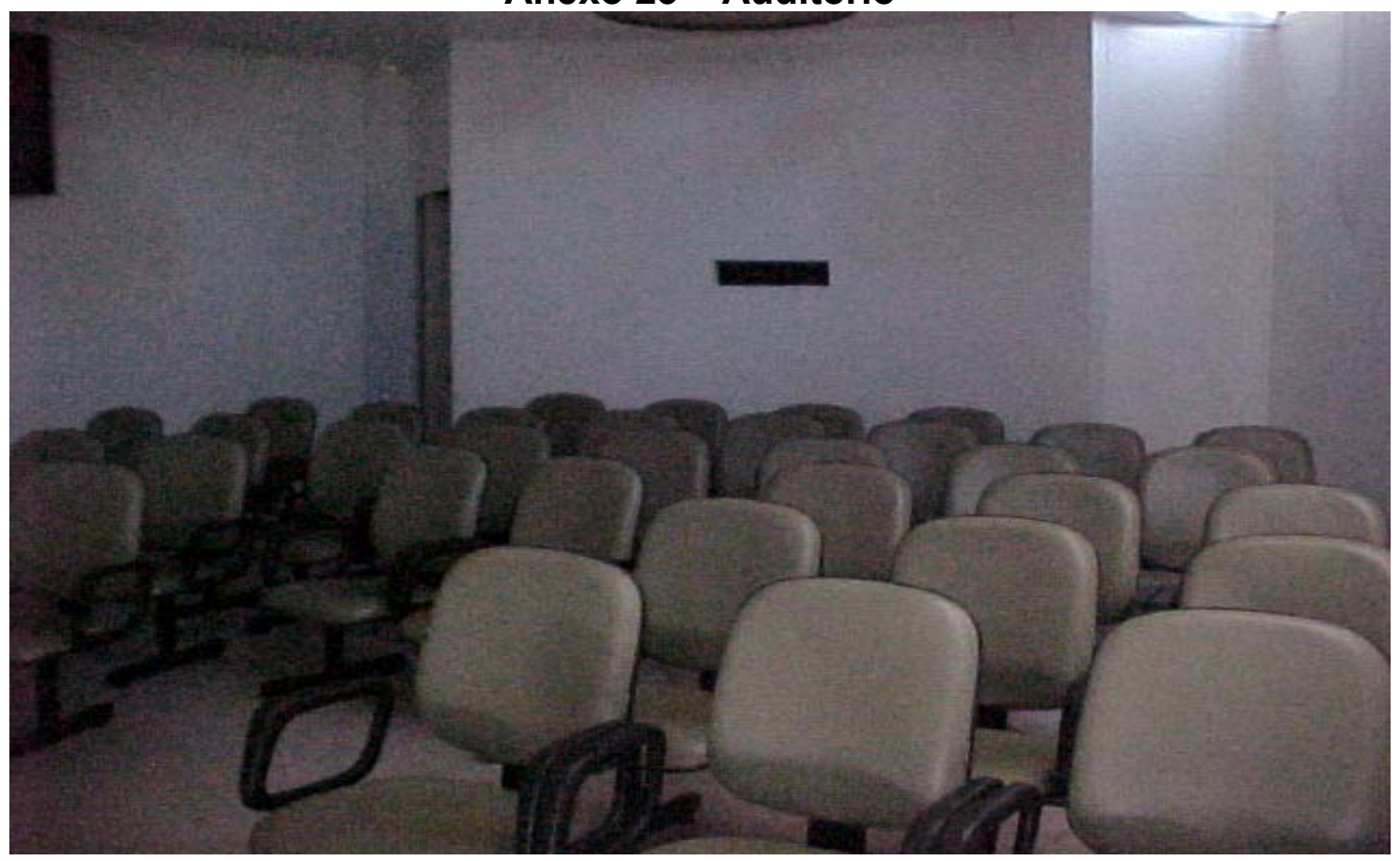

VEGETAÇÃO DO PNB

Anexo 24 - Vista para cidade. 
FOLHA DE APROVAÇÃO

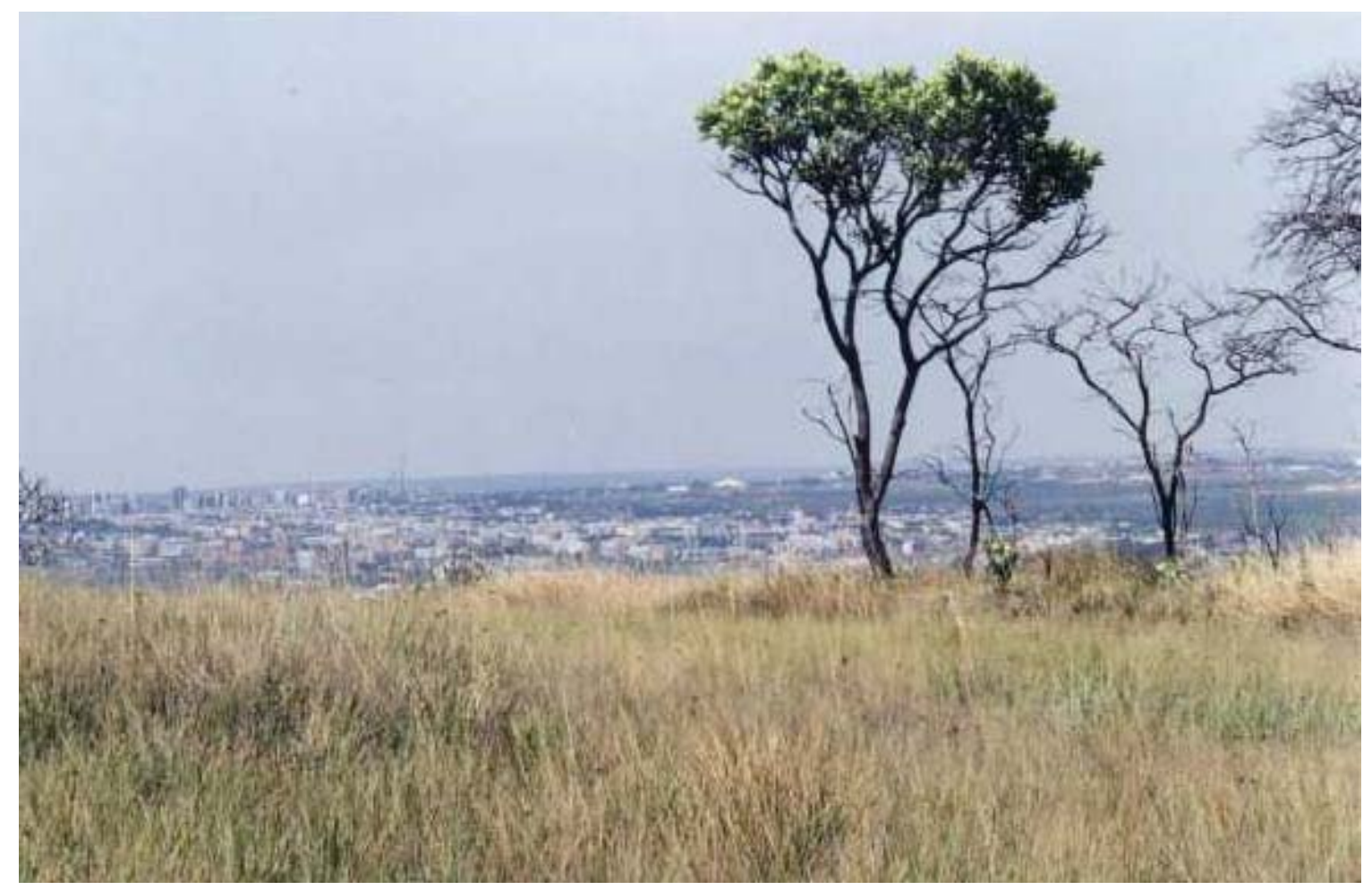

Anexo 25 - Vegetação do Cerrado. 


\section{FOLHA DE APROVAÇÃO}

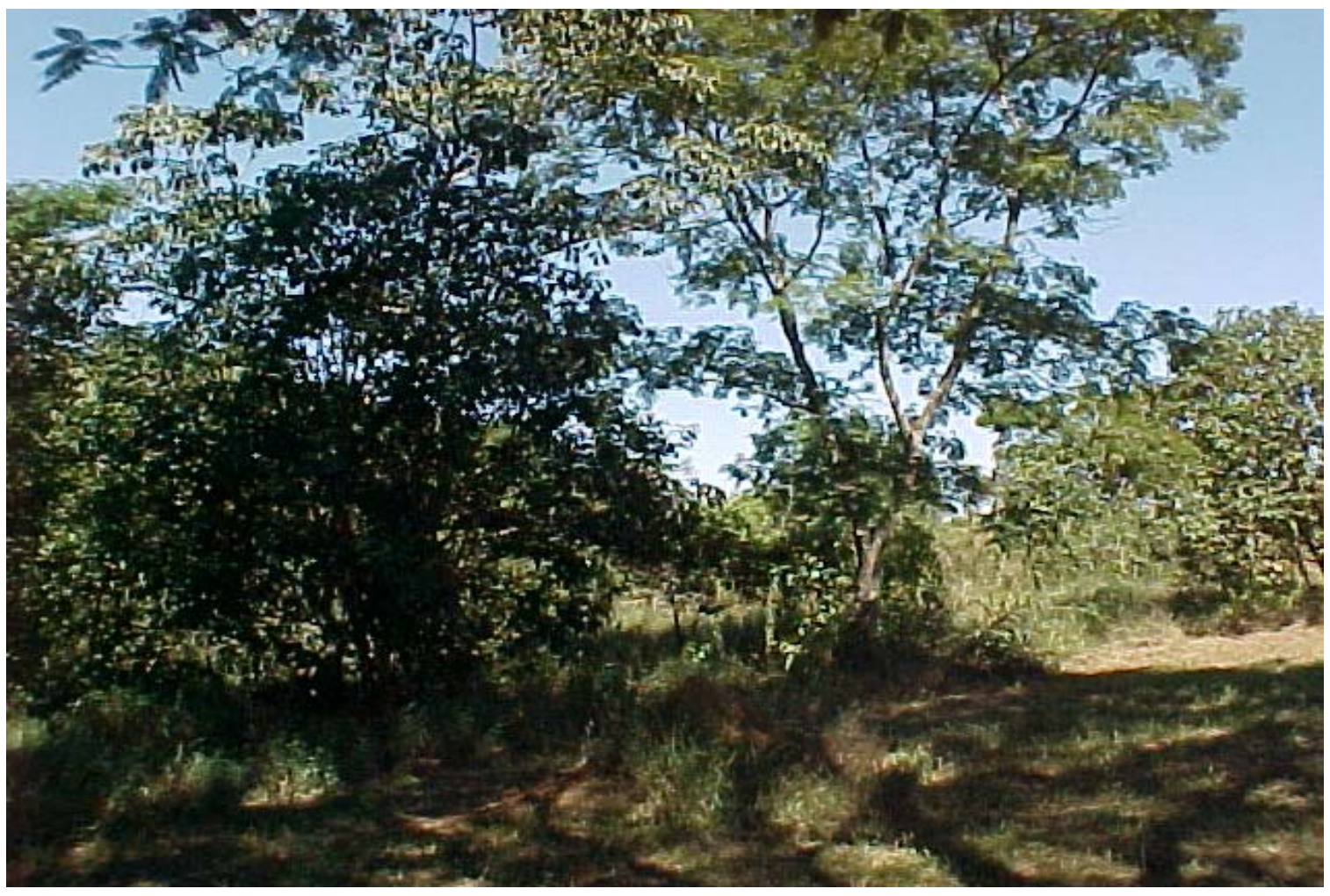

Anexo 26 - Vegetação do Cerrado. 


\section{FOLHA DE APROVAÇÃO}

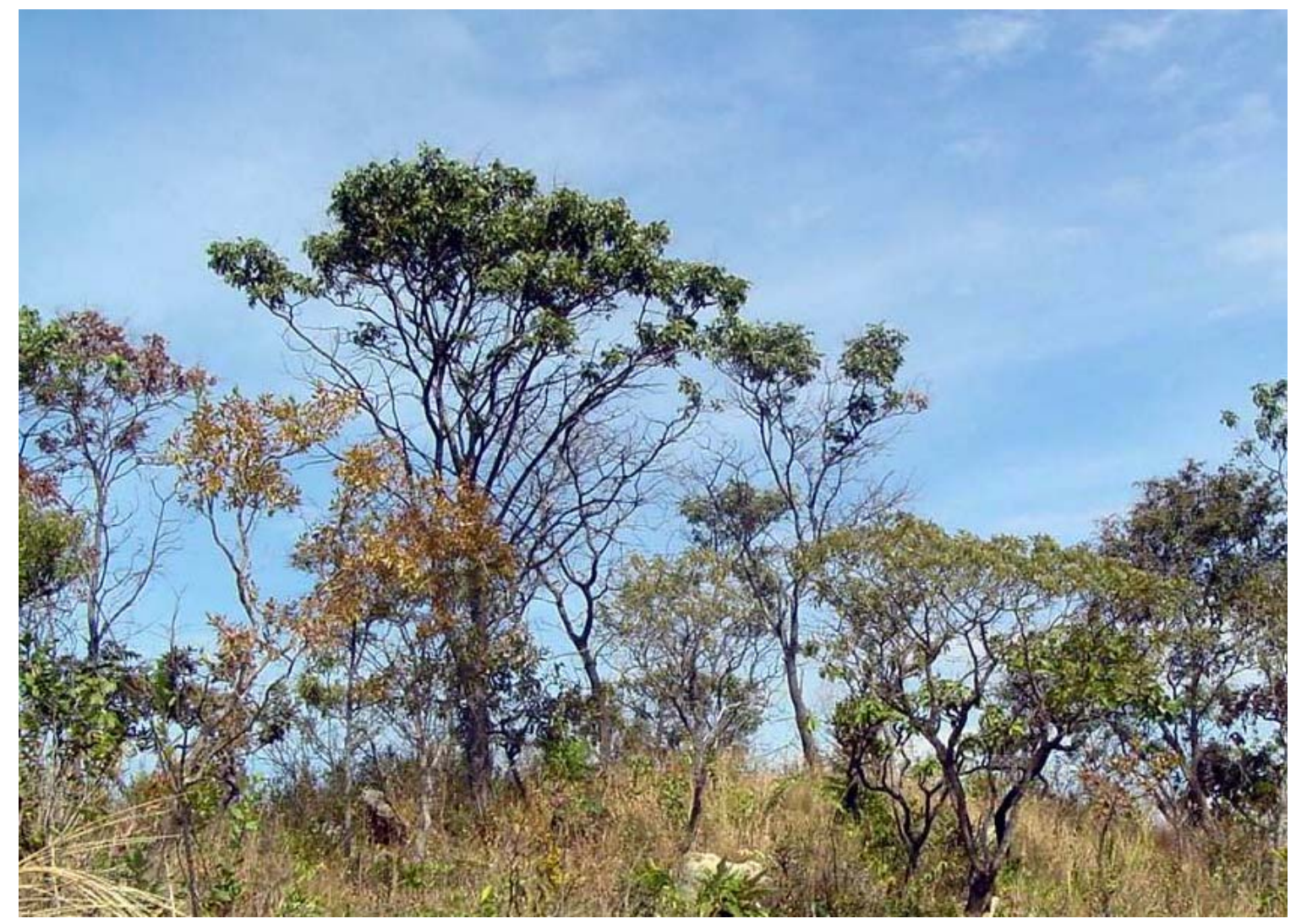


NOME COMPLETO: IDADE:

PRATICANTE DE: （ ) COOPER （）LAZER （ ) OUTROS BAIRRO:

PROFISSÃO: SEXO: $\mathrm{F}(\quad) \mathrm{M}(\quad)$ ESCOLARIDADE:

RENDA MENSAL:( ) R \$ 100 A 300 ( ) R\$ 301 A 500 ( ) R $\$ 501$ A 1000 ( ) $R \$ 1001$ A 2000 ( ) $R \$ 2001$ A 3000 ( ) $R \$ 3001$ A 5000 ( ) + R $\$ 5000$ VC COSTUMA VISITAR O PARQUE COM FREQUENCIA? ( ) SIM ( ) NÃO HÁ QUANTO TEMPO FREQUENTA O PARQUE? CONHECEU O CENTRO DE VISITANTES? （） SIM （ ) NÃO VC RECEBEU ALGUM TIPO DE INFORMAÇÃO DURANTE SUA VISITA NO PARQUE? QUE TIPO?

O QUE VC ACHOU DOS SERVIÇOS OFERECIDOS NO PARQUE?

( ) EXCELENTE （ )BOM （）REGULAR （）RUIM

O QUE VC ACHOU DA INFRA- ESTRUTURA DO PARQUE?

( ) EXCELENTE （ )BOM （）REGULAR （）RUIM

VC PAGA A DIÁRIA OU MENSALIDADE?

O QUE VC ACHA DO VALOR DO INGRESSO?

( )MUITO BARATO ( )BARATO ( )RAZOÁVEL ( )CARO ( )MUITO CARO QUANTO VC PAGARIA PELO INGRESSO AO PARQUE?

VC JÁ OUVIU FALAR EM ECOTURISMO?（） SIM （） NÃO

VC JÁ PRATICOU ECOTURISMO NO PNB? （） SIM （） NÃO

TEM VONTADE DE PRATICAR?（） SIM （） NÃO 


\section{FOLHA DE APROVAÇÃO}

1- KINKER, Sônia. Ecoturismo e conservação da natureza em parques nacionais. Coleção Turismo. Campinas: Papirus, 2002.

2- IBAMA, INSITUTO BRASILEIRO DO MEIO AMBIENTE. Disponível na Internet em: <http://www.ibama.com.br> Jul/2001

3- EMBRATUR, INSTITUTO BRASILEIRO DE TURISMO/MINISTÉRIO DO TURISMO. Disponível na Internet em :<http://www.embratur.gov.br>

4- ECOBRASIL, ASSOCIAÇÃO BRASILEIRA DE ECOTURISMO. Disponível na Internet em :<http://www.ecobrasil.org.br>

5- OMT, ORGANIZAÇÃO MUNDIAL DE TURISMO - dados e tendências mundiais. Disponível na Internet em : <http:// www.world-tourism.org>

6- GUIMARÃES, R. P. El desarrollo sustentable: propuesta alternativa o retorica neoliberal? Revista Eure, vol. XX, n. 61. Santiago Del Chile, 1994

7- SACHS, Ignacy. Estratégias de transição para o Séc. XXI: desenvolvimento e meio ambiente. São Paulo: Studio Nobel, Fundação do Desenvolvimento Administrativo,1993.

8- FIGUEIREDO, Silvio Lima. Turismo e Cultura. In: LEMOS, Amália (org.). Turismo: impactos sócio-ambientais. São Paulo, 1996.

9- FORTE, Ana Maria. Artigo sobre o Planejamento e viabilidade do ecoturismo. Disponível na Internet em : <http://www.mma.gov.br>

10- Wall, G. (1997)."Is ecotourism sustainable?" . Environmental Management, $\mathrm{n}^{\circ} 4$, vol.21

11- ZIFFER, K. A. E. Ecotourism: the uneasy alliance. Conservation International, Ernst \&Young, International Management Consulting Group (Working Papers on Ecotourism,1) Washington, DC: Island Press,1989.

12- RUSCHMANN, Dores. Turismo e planejamento sustentável: A proteção do meio ambiente. Campinas: Papirus, 1997.

13- SNUC - Sistema Nacional de Unidades de Conservação da Natureza, MMA. Brasília, 2000.

14- Borrego, C. (1994); "Sustainable Development of Coastal Zone: Why is it Important?", in Proceedings do Littoral 94; Associação EUROCOAST Portugal; Lisboa; pp. 11-23

15- Gestão dos Recursos Naturais, subsídios a elaboração da Agenda 21 brasileira. Ministério do Meio Ambiente, Instituto Brasileiro do Meio Ambiente e Recursos Naturais Renováveis, Consórcio TC/BR/FUNATURA, 2000.

16- SALGADO, G. S. M. Economia e Gestão de Áreas Protegidas: o caso do Parque Nacional de Brasília. Brasília, 2000, 124 p. Dissertação (Mestrado em Gestão Econômica do Meio Ambiente), Universidade de Brasília - UnB, Instituto de Ciências Humanas, Departamento de Economia. 


\section{FOLHA DE APROVAÇÃO}

17- OVIEDO, G. Áreas Protegidas y Comunidades Locales. Artigo baseado na ponencia presentada no IV Congresso Mundial de Áreas Protegidas e o resultado das deliverações do sub-grupo2, ofician I.1. Fundación Natura, 1992.

18- CASES, Olatz. Documento de Informações Básicas sobre as principais Correntes Filosóficas e Conceituais de Conservação das Áreas Protegidas, com ênfase para América Latina. IBAMA/DIREC/DEUC, Brasília, 1995, 66p.

19- FIGUEIREDO, L. A. V. Ecoturismo e participação popular no manejo de áreas protegidas: aspectos conceituais, educativos e reflexões. In Adyr Balastreri Rodrigues (org.) "Turismo e Ambiente - Reflexões e Propostas". Hucitec, São Paulo, 1997,177p.

20- IBDF - Instituto Brasileiro de Desenvolvimento Florestal / FBCN Fundação Brasileira para Conservação da Natureza, Plano de Manejo do Parque Nacional de Brasília, 1979, 52p.

21- RAMOS. P. C. M., 1995. Vegetation communities and soils in the National Park of Brasília. Ph.D. thesis. Department of Geography, University of Edinburgh. Edinburgh.

22- FELFILI, J. M., SILVA JÚNIOR. M. C., REZENDE, A. V., MACHADO, J. W. B.,WALTER, B. M. T. \& SILVA, P. E. N. 1994. Vegetação Arbórea. In Felfili et. al.(eds), Projeto Biogeografia do Bioma Cerrado - Vegetação e Solos. Caderno de Geociências do IBGE 12: pp. 75-166.

23- WALTER, B. M. T.; SAMPAIO, A. B.; GUARINO, E. S. G.; CORDOVILSILVA, S. P.; SANTOS, A. A.; PEREIRA, J. B. 1999. Fitossociologia de um trecho de mata de galeria inundável no Parque Nacional de Brasília, DF. In: $50^{\circ}$ Congresso Nacional de Botânica, Blumenau. Resumos. Blumenau, SC. 1999. p.273

24- IBAMA - Instituto Brasileiro de Meio Ambiente e dos Recursos Naturais Renováveis / FUNATURA - Fundação Pró-Natureza. Plano de Manejo do Parque Nacional de Brasília,1998.

25- ENEB - Encontro Nacional de Estudantes de Biologia/UnB. Envolvimento Sustentável - Vivenciar para Atuar. Brasília, 2002. Disponível na Internet em : $<$ http://www.unb.br/>

26- UNESCO - Organização das Nações Unidas para Educação, a Ciência e a Cultura. Disponível na Internet em: <http://www.unesco.org.br>

27- BORRINI-FEYERABEND, G. Collaborative Management of Protected Areas: Tailoring the Approach to the Context. IUCN Social Policy Group, 1996, $40 \mathrm{p}$.

28- ZUBE, E. H. No Park is a Island. In Jeffrey McNeely (ed.) "Expanding Partnerships in Conservation", Island Press, IUCN, Washington, D.C,1995,302 p. 


\section{FOLHA DE APROVAÇÃO}

29- FREEMUTH, J. C. National Parks and the Political of External Threats. University Press of Kansas, 1991, 186 p.

30- SALGADO G.S.M. Público, mas sem público, Gazeta Mercantil, 15 de outubro de 2001.

31- IUCN - International Union for Conservation of Nature and Natural Resources.. Economic Values of Protected Areas - Guidelines for Protected Area Managers, 1998, $52 \mathrm{p}$.

32- CARVALHO, Caio Luiz de. Na busca do Turismo que queremos. In: LAGE, Beatriz Helena Gela, MILONE, Paulo César (Org.) Turismo: Teoria e Prática São Paulo: Atlas, 2000.

33- MERCADANTE, M. Criação e gesta de áreas protegidas: um assunto para técnicos ou uma questão política? . Artigo não publicado, 1998,7p.

34- PETROCCHII, Mário. Turismo: Planejamento e gestão - São Paulo: Futura, 1998.

35- SAAB, William George Lopes. Considerações sobre o desenvolvimento do setor de turismo no Brasil. BNDES Setorial, Rio de janeiro, $n^{\circ} 10, p-285-312$, set. / 1999.

36- MMA, MINISTÉRIO DO MEIO AMBIENTE. Disponível na Internet em: <http://www.mma.gov.br>. Brasília, Jul/2001. 


\section{FOLHA DE APROVAÇÃO}

Atrativo - É todo lugar, objeto, equipamento ou acontecimento de interesse para o turismo. Que tem força de atrair; natureza que atrai.

Biodiversidade - determina a diversidade biológica entre os seres vivos; está associada à diversidade do genoma de cada espécie e de cada indivíduo e conseqüentemente ao ecossistema.

Bioma - é um espaço ecológico, um conjunto de comunidades, caracterizado por diversas particularidades geográficas, como as temperaturas médias e as precipitações anuais, além fauna e flora que nele vivem.

Cerrado - é uma formação típica do Brasil Central. Impressiona pelas árvores e arbustos retorcidos, caules recobertos de espessas cascas e folhas grossas, brilhantes ou revestidas por um denso conjunto de pêlos.

Conservação - Ato ou efeito de conservar; conjunto de medidas de caráter operacional; intervenções técnicas e científicas, periódicas ou permanentes que visam a conter as deteriorações em seu início.

Degradado - Recurso natural desgastado, enfraquecido ou estragado.

Desenvolvimento Sustentável - é progredir sem diminuir as perspectivas das gerações futuras.

Diagnóstico - conhecimento e coleta de dados de uma área estudada, avaliar, determinar uma situação.

Diretrizes - critérios estabelecidos, normas.

Ecologia - Estudo das relações dos seres vivos e o ambiente em que vivem. Ecossistema - Sistema que se forma pela influência ou ação recíproca que ocorre entre os fatores físicos e químicos de um ambiente os organismos vivos neles existentes. 


\section{FOLHA DE APROVAÇÃO}

Fomentar - Promover o desenvolvimento de; exercitar; excitar; facilitar; estimular.

Monitoração - Acompanhamento; controle; observação; fiscalização; direção.

Preservação - Proteção e uso racional de recursos e do meio.

Zoneamento - é a divisão da área em distintas zonas. No caso de uma reserva natural, o zoneamento serve para designar que atividades serão realizadas em que porção da área. 